JAQUELINE SANTA BRÍGIDA SENA

\title{
O DOGMA DA NEUTRALIDADE NA PRESTAÇÃO JURISDICIONAL: UMA ABORDAGEM JUSFILOSÓFICA A PARTIR DO PENSAMENTO DE LUIS ALBERTO WARAT
}

Dissertação de mestrado

Orientadora: Professora Doutora Lidia Reis de Almeida Prado

UNIVERSIDADE DE SÃO PAULO

FACULDADE DE DIREITO

SÃO PAULO, 2010 
JAQUELINE SANTA BRÍGIDA SENA

\title{
O DOGMA DA NEUTRALIDADE NA PRESTAÇÃO \\ JURISDICIONAL: UMA ABORDAGEM JUSFILOSÓFICA A PARTIR DO PENSAMENTO DE LUIS ALBERTO WARAT
}

\begin{abstract}
Dissertação de mestrado apresentada à Faculdade de Direito da Universidade de São Paulo como requisito parcial para obtenção do título de mestre em Direito.

Área de concentração: Filosofia e Teoria Geral do Direito.

Orientadora: Professora Doutora Lidia Reis de Almeida Prado.
\end{abstract}

UNIVERSIDADE DE SÃO PAULO

FACULDADE DE DIREITO

SÃO PAULO, 2010 
Autorizo a reprodução e divulgação parcial deste trabalho, por qualquer meio convencional ou eletrônico, para fins de estudo e pesquisa, desde que citada a fonte. 
NOME: SENA, Jaqueline Santa Brígida.

Título: O dogma da neutralidade na prestação jurisdicional: uma abordagem jusfilosófica a partir do pensamento de Luis Alberto Warat.

Dissertação de mestrado apresentada à Faculdade de Direito da Universidade de São Paulo para obtenção do título de mestre em Direito

Aprovada em:

BANCA EXAMINADORA:

$\operatorname{Prof}(a) . \operatorname{Dr}(a)$.

Instituição:

Julgamento:

Assinatura:

Prof(a). Dr(a).

Instituição:

Julgamento:

Assinatura:

Prof(a). Dr(a).

Instituição:

Julgamento:

Assinatura: 
Dedicado a Wilson Levy Braga da Silva Neto, que, segurando a minha mão desde o início, convenceu-me da possibilidade de realizar este sonho. E que, todos os dias, faz-me acreditar na existência do amor e que, através dele, é possível transformar a mim, a nós e ao mundo. 


\section{AGRADECIMENTOS}

Em primeiro lugar, agradeço à Prof ${ }^{a}$. Dr ${ }^{a}$. Lidia Reis de Almeida Prado, a quem devo grande parte das descobertas que fiz neste caminho da pesquisa, e cuja doçura, inteligência e vivacidade tornaram mágicos estes anos de orientação. A ela, os meus profundos e sinceros agradecimentos, meu eterno respeito e admiração.

Agradeço ao Prof. Dr. Eduardo Bittar e ao Prof. Dr. José Renato Nalini, não apenas por terem aceitado participar de minha banca examinadora, mas por terem contribuído para a minha formação pessoal e acadêmica, e pelo carinho e respeito com que sempre me trataram.

Agradeço aos meus pais Francisco Canindé da Costa e Margarida Santa Brígida Sena, e à minha irmã, Carolina Sena, que sempre estiveram do meu lado, incentivando-me a lutar pelos meus sonhos e vibrando a cada conquista minha, que é deles também.

Agradeço a todos os meus amigos, especialmente a Brunela Vieira de Vincenzi, Cristina Célia Garcia, Elisa Pires da Cruz, Gabriel Macedônio de Sá, Gabriela Saraiva Vicente de Azevedo, João Marcos de Araújo Braga Jr, Luíza Ugarte da Silveira, Paula Straus Maciel e Vitor Souza Lima Blotta, que acompanharam as diversas fases desta pesquisa, auxiliandome, cada um a seu modo, a enfrentar e superar as adversidades que encontrei pelo caminho.

Agradeço, também, a Antoin Aboul Khalil, que compartilhou comigo estes anos de orientação, dividindo os momentos agradáveis e principalmente os difíceis, e a quem desejo uma carreira acadêmica brilhante.

Agradeço, em especial, aos meus colegas de trabalho Edmilson dos Santos Silva, Juliana Medeiros Garrido de Paula, Lílian Carvalho Toninato, e ao meu chefe, Des. Antônio Luis de Carvalho Viana, por compreenderem este momento de minha vida e por estarem sempre dispostos a me ajudar.

Agradeço ao meu namorado, Wilson Levy Braga da Silva Neto, pois sem os seus sorrisos, seu incentivo e seu amor, eu não teria concluído mais esta etapa; e também aos seus pais, Wilson Levy Braga da Silva Jr. e Nadir Aparecida Semenzin Braga da Silva, bem como a Waldemar Semenzin, pelo enorme carinho com que me tratam e pelo incentivo à minha carreira.

Agradeço a todos os professores que participaram da minha formação e, em especial, à Prof ${ }^{a}$. Dr ${ }^{a}$. Angélica Luciá Carlini, grande incentivadora da minha carreira acadêmica, desde os tempos de faculdade, e a Luis Alberto Warat, cujos ensinamentos transformaram a minha visão a respeito do Direito, e que, construindo uma aura mágica ao seu redor, convoca democraticamente todos os interessados a com ele refletir. Agradeço a ele por poder participar desses diálogos e pelo afeto que sempre dispensou a mim e ao meu namorado, Wilson Levy.

Agradeço, também, aos colegas do grupo de pesquisa Democracia, Justiça e Direitos Humanos - Estudos de Teoria Crítica (DJDH), pelas discussões e troca de ideias sempre enriquecedoras.

Agradeço, por fim, à Coordenação de Aperfeiçoamento de Pessoal de Nível Superior CAPES, pelo financiamento parcial desta pesquisa. 
Ousar é um privilégio dos que têm coragem

Luis Alberto Warat 


\section{PARTE 1 - A GÊNESE DO IMPERATIVO DE NEUTRALIDADE NA PRESTAÇÃO JURISDICIONAL}

1.1. - Modernidade, Estado moderno e divisão dos poderes 20

1.2.- Modernidade, pensamento científico moderno e ciência do Direito. 34

PARTE 2 - A OBRA DE LUIS ALBERTO WARAT E A BUSCA DE UMA NOVA EPISTEMOLOGIA PARA A CIÊNCIA DO DIREITO: REFLEXÕES QUE PERMITEM REPENSAR O PARADIGMA DE NEUTRALIDADE DA MAGISTRATURA

2.1. - A proposta de uma semiologia política e a identificação do "senso comum teórico dos juristas" como necessárias à construção de um saber crítico do Direito.

2.1.1. - Situando a obra waratiana no contexto da Filosofia da Linguagem.

2.1.2. - A semiologia do poder de LuIS Alberto WARAT. 68

2.1.3. - Senso comum teórico dos juristas: noções precursoras, conceito e desdobramentos

2.2 - Senso comum teórico dos juristas, ciência do Direito e magistratura: é possível cogitar de neutralidade na prestação jurisdicional? 


\section{Introdução}

As palavras de qualquer linguagem são sempre promessas de um sentido. Toda palavra está sempre condenada a ser um começo. Nenhuma palavra pode ser mais do que um começo, um começo de seus usos. E em cada uso a encontramos como começo. Quando se fala ou se está escrevendo, se está sempre começando. O texto já elaborado é um começo morto, que revive em cada leitor. Os juristas, em geral, nunca conseguiram compreender esta condição das palavras, as vivem sempre como se não tivessem começo. As vivem como palavras mortas, que não podem nunca recomeçar. São as palavras da lei, dizem. Cada vez que um juiz interpreta uma lei, a recomeça? Tampouco se poderia afirmar isso. Eles são institucionalmente prisioneiros de ilusões alheias. (WARAT, Luis Alberto. In Lugares Desconhecidos, p. 22)

Já não há possibilidade de retorno ao hermetismo, à luz do texto constitucional vigente. O Judiciário, no Brasil, nunca mais será o mesmo. E se vier a declinar essa missão, recolhendo-se a uma neutralidade inviável, a uma assepsia imprópria ao desempenho de um órgão do Estado, continuará a assistir ao seu enfraquecimento institucional, até transformar-se em função burocratizada e de escassa importância. (NALINI, José Renato. In A Rebelião da Toga, p. 310)

Muitas são as expectativas sociais depositadas na figura do magistrado. Dele se espera que conheça o Direito (iura novit curia); dele se espera, de um lado, que saiba usar a força da espada de Palas Athena, para que os homens sintam o peso do dever de obediência à lei; e, de outro, que tenha sabedoria e aptidão suficientes para manejar a balança, cujos pratos podem pender sempre para qualquer um dos lados, num equilíbrio raro a ser encontrado. Dele se espera que seja diligente, que possa dar a solução adequada às mais diversas controvérsias, que preste um trabalho célere e, sobretudo, que não erre. Dele se espera o exemplo de cidadão. E, como se não bastasse, quase que de forma mítica (e por que não dizer sobre-humana?), dele se espera neutralidade no julgamento, como condição de realização da verdadeira Justiça.

$\mathrm{O}$ imperativo de neutralidade na atuação jurisdicional nasce juntamente com o Estado e o Direito modernos. Esse processo acontece no bojo do chamado Iluminismo, movimento filosófico e cultural nascido na Europa, no século XVIII, que visava à emancipação do homem através da razão, preconizando os valores do racionalismo, do individualismo e do universalismo.

O racionalismo implicava o desencantamento do mundo, o combate ao dogmatismo religioso e às explicações metafísicas sobre o universo. Implicava também a fé na ciência, que teria caráter emancipatório, na medida em que permitiria ao homem o domínio da natureza e o libertaria das superstições. O individualismo conferiu um novo status à condição humana, atribuindo ao homem um valor ético concreto, separado da coletividade. 
Finalmente, o universalismo relacionava-se com a extensão desse projeto civilizatório, que visaria a todos os seres humanos independentemente de suas características pessoais, evitando-se preconceitos causadores de conflitos. ${ }^{1}$

Inseridos nesse momento cultural, os sistemas político e jurídico passam de “irracionais" para "racionais"2. Se o Rei era o soberano absoluto, personificação do poder divino e, portanto, fonte da qual emanava todo o Direito, o poder político, com a criação dos Estados Nacionais, passa para as mãos do povo. O Estado moderno liberal surge, portanto, como limitação ao poder político antes exercido pelo soberano, encontrando suas bases, principalmente, no valor da soberania da nação. Sujeito ao império da lei, o governante não pode abusar de seu poder de punir e muito menos atentar contra os direitos e liberdades dos cidadãos. Isso traz inevitáveis repercussões para o Direito, pois é através do ordenamento jurídico que o Estado moderno se estrutura. É nesse momento que ocorre a codificação dos direitos do homem e do cidadão, e a consagração dos princípios da anterioridade das infrações e das penas, da supremacia da lei, e da separação dos poderes, este último de especial importância para a discussão acerca da neutralidade na prestação jurisdicional que se pretende travar.

Com o fim das monarquias absolutas e o advento do liberalismo, opera-se a descentralização dos poderes, que até então estavam concentrados na nobreza e no clero. A partir das ideias iluministas, nasce a percepção de que as funções de elaborar as leis, executá-las e julgar os conflitos intersubjetivos não poderiam permanecer concentradas nas mãos de um único sujeito, sob pena de se perpetuar um governo tirânico e opressor. Em contraposição a esse modelo, consolida-se uma nova forma de Estado, na qual o poder do soberano é dividido em partes, que poderiam controlar-se entre si. Legislativo, Executivo e Judiciário são dotados de atribuições bem definidas, pois somente assim a liberdade política estaria garantida aos cidadãos: com a autolimitação dos poderes do Estado, ficava assegurado o direito de "não ser obrigado a fazer ou deixar de fazer alguma coisa senão em virtude de lei"3.

Nesse contexto, nasce a figura do juiz neutro, que deve limitar-se a aplicar as leis

\footnotetext{
${ }^{1}$ A esse respeito, cf. ROUANET, Sergio Paulo. Mal-estar da Modernidade. São Paulo: Martins Fontes, 2003.

${ }^{2}$ Cf. GILLISSEN, John. Introdução Histórica ao Direito. $3^{\text {a }}$ ed. Lisboa: Fundação Calouste Gulbenkian, 2001, p. 205.

${ }_{3}^{3}$ Percebe-se que um dos sustentáculos do Direito Moderno é a concepção de liberdade enquanto possibilidade de se comportar de acordo com a lei, ou seja, segundo o princípio da legalidade. A esse assunto se retornará adiante.
} 
nos exatos moldes em que foram elaboradas, de modo a se garantir a inviolabilidade dessa nova estrutura estatal. Em nome da separação dos poderes, o juiz não seria um órgão dotado de vontade própria, em razão do quê suas decisões deveriam espelhar, com exatidão, as palavras da lei. Não por outro motivo, MONTESQUIEU, importante teórico do Estado Moderno, definiu os juízes como sendo "a boca que pronuncia as palavras da lei, seres inanimados que não podem moderar nem sua força, nem seu rigor"4.

Sobre o contexto de nascimento da exigência de neutralidade na prestação jurisdicional, pondera LIDIA REIS DE ALMEIDA PRADO:

No Iluminismo, concebia-se o Estado com atribuições bem definidas exercidas pelos três poderes. Ao juiz cabia julgar e, para a garantia dos direitos, contava-se com a neutralidade da Justiça, que seria atingida caso se isolasse o magistrado da sociedade, do Legislativo e do Executivo. Dessa forma desenvolveu-se a concepção de um Judiciário neutro, como se fosse um produtor de conhecimento científico e, como tal, imune a influências externas. (...). Após a revolução francesa, a vitória da burguesia trouxe para o pensamento jurídico a tendência da preservação dos interesses individuais, limitados apenas pela norma, expressão dos ideais coletivos. Dessa tendência decorreram, como conseqüências, um extremo apego à lei na interpretação e aplicação do Direito pelo juiz, assim como a proibição, imposta ao Judiciário, de participar da criação jurídica, atividade exclusiva do Legislativo, órgão representante da vontade popular. Tais conseqüências reforçavam o ideal de neutralidade do magistrado. $\mathrm{O}$ mesmo ocorria com a concepção mecânica da função jurisdicional, segundo a qual a formulação da sentença deveria assemelhar-se a um mero silogismo, em que a premissa maior seria a lei, a menor, o fato e a conclusão, a sentença. ${ }^{5}$

Ocorre que, ao lado desse dogma de neutralidade, paradigma que ainda se faz presente na atualidade, parece haver uma crise de legitimidade das instituições e, junto a estas, do Direito. O sentimento de insatisfação social diante de um Estado que não tem conseguido realizar suas promessas é intenso. Recente pesquisa divulgada pela Associação dos Magistrados do Brasil (AMB) mostra que mais de $80 \%$ da população não confia no Congresso Nacional nem nos partidos políticos, e cerca de metade dos brasileiros não confia no Poder Judiciário. ${ }^{6}$ A Lei, portanto, não é mais concebida como paradigma de Justiça. A sensação geral é de impunidade, principalmente para os economicamente abastados, e a de que não vale a pena lutar pelo Direito se a resposta jurisdicional nunca chega, ou se, quando chega, não é efetiva. A esse respeito, JosÉ RENATO NALINI, em seu

\footnotetext{
${ }^{4}$ MONTESQUIEU. Do espírito das leis. Livro XI, capítulo 6. Tomo I. São Paulo: Ed. Difusão Européia do Livro, 1962, p. 187.

${ }^{5}$ PRADO, Lidia Reis de Almeida. Neutralidade e imparcialidade dos juízes? In GROENINGA, Giselle Câmara; PEREIRA, Rodrigo (Coord.). Direito de família e psicanálise: rumo a uma nova epistemologia. Rio de Janeiro: Imago, 2003, p. 37.

${ }^{6}$ A Imagem das Instituições Públicas Brasileiras. Brasília-DF, Set. 2007. Pesquisa realizada por Opinião Consultoria, a pedido da AMB.
} 
texto A Rebelião da Toga, afirma:

O Legislativo, antigamente reconhecido como caixa de ressonância das aspirações populares, também se transformou. Se a lei já não é a relação necessária que se extrai da natureza das coisas para ser resposta contingente e conjuntural a uma necessidade imediata, o Parlamento perdeu também sua qualidade de formulador de regras genéricas de conduta. Passou, modernamente, a ser provido por quadros escolhidos em eleição com suspeita de mácula. Quem elege não é o povo, mas o poder econômico. Até os políticos honestos pagam tributo à sensação geral de falta de escrúpulos. ${ }^{7}$

E continua, preciso:

Simples de se concluir: se o juiz é o clássico aplicador da lei ao caso concreto e se a lei padece de legitimidade, no exato sentido do consentimento e de adequação entre a previsão e os fins anunciados, sua função encontra-se questionada.

É nesse contexto que os moldes da atuação judicial passam a ser questionados. A crise de legitimidade do Estado Democrático de Direito é patente. Para verificá-la, no caso brasileiro, basta o sentimento de insatisfação gerado pelo simples manusear da Carta Constitucional de 1988. Passaram-se vinte anos de sua promulgação e nem de longe se notam os avanços sociais esperados. O Estado perde paulatina e sistematicamente sua função representativa e, com isso, produz normas cada vez menos capazes de solucionar demandas complexas, próprias do Brasil contemporâneo. Isso não se reflete apenas no Executivo, que, por impossibilidade material ou pela gestão inadequada do erário, deixa de atender às necessidades do povo, ou no Legislativo, que, como se disse, não consegue regular adequadamente as relações sociais. Afeta, sobretudo, o Judiciário, locus onde deságuam todas as demandas não atendidas e do qual se espera uma resposta pronta e efetiva, mas que também não tem desempenhado satisfatoriamente sua função de pacificador de conflitos.

A figura do juiz, concebida modernamente como mero aplicador da norma, não pode subsistir. Antes se pensava que a neutralidade do julgador é que garantiria o resultado justo. Isso porque a lei, confeccionada pelo "legislador racional", , seria aplicada a todos indistintamente. Hoje, percebe-se que a distorção dos ideais constitucionais e a injustiça

\footnotetext{
${ }^{7}$ NALINI, José Renato. A Rebelião da Toga. $2^{\text {a }}$ ed. Millennium, Campinas: 2008, p. 06.

${ }^{8}$ Sobre essa figura, explica Tércio Sampaio Ferraz Jr.: "Trata-se de uma construção dogmática que não se confunde com o legislador normativo (o ato juridicamente competente conforme ordenamento) nem com o legislador real (a vontade que de fato positiva normas). É uma figura intermédia, que funciona como um terceiro metalinguístico em face da língua normativa (LN) e da língua-realidade (LR). A ele a hermenêutica se reporta quando fala que o 'legislador pretende que...', 'a intenção do legislador é que...', ou mesmo 'a mens legis nos diz que...". Introdução a Estudo do Direito - técnica, decisão, dominação, $2^{\mathrm{a}}$ ed. São Paulo: Atlas, 1994, p. 280.
} 
são provocadas, justamente, pelo magistrado que permanece em seu tablado, acima das partes, e não desce à realidade para assumir seu papel de agente político e transformador. No contexto de um Estado ineficaz, que não garante sequer a concretização dos direitos fundamentais, a neutralidade do magistrado, antes sinônimo de Justiça, agora constitui hermetismo judicial, cuja permanência implica a manutenção do status quo e, portanto, a perpetuação de desigualdades.

É nesse cenário que o presente trabalho se insere. A tarefa, aqui, será contribuir para a desconstrução do imperativo de neutralidade do magistrado como forma de enfrentamento da crise de legitimidade do Judiciário. Não se ignora que tal crise possa ser atribuída ao entrecruzamento de diversos fatores - tais como o acúmulo de processos e a escassez de pessoal, a burocratização do serviço, uma estrutura processual que não colabora para a celeridade dos feitos e, principalmente, uma certa cultura da litigância, que judicializa todo e qualquer conflito, ignorando as vias alternativas de solução das controvérsias. Contudo, não nos parece que, uma vez resolvidos esses problemas, essa crise restaria superada. De nada adiantará a superação dos desafios materiais se o componente humano permanecer inalterado. Poucos avanços serão sentidos se, modificados os instrumentos, o operador continuar a manuseá-los da mesma forma.

Como mostraram as contribuições teóricas de VieHWEg e CHAIM PERELMAN, entre outros, a atuação judicial consubstancia-se num esforço de exposição coerente dos argumentos utilizados na tomada de decisão, ou seja, de justificação de seus fundamentos. Verifica-se, a partir desses autores, que a atividade do juiz é eminentemente argumentativa e retórica. E, portanto, o magistrado, sem dar-se conta, torna-se refém dos limites da linguagem.

Dessa forma, a fim de melhor compreender-se a atividade judicial, é imprescindível analisar as relações existentes entre Direito e Linguagem. Para tanto, optou-se por fazê-lo a partir do pensamento de LUIS ALBERTO WARAT, jusfilósofo que dedicou grande parte de sua produção acadêmica a essa temática.

Argentino naturalizado brasileiro, WARAT é autor de mais de 40 livros e de diversos artigos. Influenciado pela Escola Analítica de Buenos Aires e profundamente marcado pela postura pedagógica de seu mestre AMBROSIO GIOJA, pretendeu libertar-se da fogueira de vaidades que se seguiu à morte de seu mestre, na luta por sua sucessão, na Universidade de Buenos Aires. Decidiu tornar-se um pensador "femininamente libertário", 
que, em suas palavras "tentou fazer uma crítica profunda da visão cartesiana do mundo na qual a razão e seus excessos se sobrepõem sempre ao corpo e à compreensão do mundo pelos sentimentos"9. Perseguido pela ditadura militar na Argentina, veio exilado para o Brasil, no início da década de 1970, e logo passou a lecionar na Faculdade de Direito da Universidade Federal de Santa Catarina, onde ministrou aulas da disciplina Teoria Geral do Direito e Epistemologia Jurídica, inédita no Brasil.

Além de se dedicar ao estudo da Epistemologia Jurídica, WARAT produziu obras importantíssimas a respeito da inter-relação dos temas Linguagem e Direito, dentre as quais se destacam Semiótica e Direito (1972), Mitos e Teorias na Interpretação da Lei (1979) e Direito e sua Linguagem (escrito em 1974, e revisto em 1984 e em 1995). Dedicou-se também à questão da metodologia e ensino do Direito, tendo fundado a Associação Latino-americana de Metodologia do Ensino do Direito (ALMED) e publicado diversos textos a esse respeito.

Em obra comemorativa dos vinte anos da chegada de LUIS AlBERTo WARAT no Brasil $^{10}$, a professora DiLSA MONDARDO, atual docente da Universidade do Sul de Santa Catarina (UNISUL), afirma que o percurso intelectual do autor é bastante complexo e de intensas mutações, o que dificulta sua organização expositiva. Segundo ela, ainda que, para alguns, o pensamento waratiano pareça um tanto caótico e dispersivo, trata-se de um discurso polifônico - numa clara remissão à noção bakhitiniana de polifonia, bastante utilizada por WARAT. Uma fala polifônica é aquela que reverbera muitas outras vozes além daquela do próprio sujeito de fala, ou seja, um discurso que se desenvolve de maneira heterogênea, porque reconhece em si a presença do outro, e que não se pretende autoritário, porque a fala enunciada resulta, justamente, da co-existência dessas diversas vozes, sem que uma prevaleça sobre as demais.

DILSA sugere uma divisão da obra waratiana em cinco momentos distintos, mas não estanques e que possuem pontos de comunicação. O primeiro, denominado por ela de "técnico-instrumental e antidogmático", é o período em que desperta no autor a preocupação com as questões pedagógicas no ensino do Direito. O segundo, que intitulou “epistemológico", tem início com a III Jornada da ALMED, quando então a problemática epistemológica foi inserida no bojo da discussão a respeito do ensino do Direito. O terceiro

\footnotetext{
${ }^{9}$ MONDARDO, Dilsa. 20 anos rebeldes: Direito a luz da proposta filosófico-pedagógica de Luis Alberto Warat. Florianópolis, Ed. Diploma Legal, 2000, p. 12.

${ }^{10}$ MONDARDO, Dilsa. Op. Cit.
} 
momento seria o "político afetivo", período em que a atenção de WARAT, acompanhado de LEONEL SEVERo RoCHA, se volta para o estudo da relação entre Direito e Linguagem, que culmina com a proposta de criação de uma "semiologia do poder" ou "semiologia política”, influenciada claramente pelas idéias de ROLAND BARTHES e MiKHAIL BAKHTIN. Nesse mesmo período, nasce a preocupação com a dimensão afetiva do ensino do Direito, reprimida pelos moldes tradicionais do ensino jurídico. Em seguida, WARAT passa pelo momento a que DILSA chamou de "carnavalização no ensino e no discurso jurídicos", em que ele intensifica a crítica e propõe a desconstrução dos métodos utilizados nas escolas de Direito. Sobrevém, então, o momento "psicanalítico", em que o autor passa aos estudos de psicanálise freudiana e estética, especialmente a partir de DELEUZE e GUATTARI, ambicionando pensar o tema da necessidade de reconstrução da subjetividade e da alteridade perdidas na Modernidade, fundando o que ele chama de "semiologia do desejo", e relacionando-a com a questão da Democracia e dos Direitos Humanos.

Caleidoscópico e cheio o autor de vida que é, WARAT parece vivenciar um novo momento, que talvez possa ser apontado como a sexta fase de sua obra, que ele próprio denominou "materialismo mágico". Ele aposta que, antes de se reconstruírem as condições materiais de existência, é absolutamente indispensável repensar a reconstrução da própria subjetividade e da capacidade de reconhecimento do outro, o que implica o estreitamento da relação entre Direito e Arte. ${ }^{11}$

Uma vez delineado o percurso intelectual do autor, faz-se necessário apontar a fase de sua obra a que o presente trabalho dará maior ênfase. É entre os momentos que DiLSA MONDARDO chamou de "epistemológico" e "político afetivo", por volta do anos 80, que WARAT desenvolve a noção que será central no presente trabalho. Ao estudar as relações entre Direito e linguagem é que o autor detecta a existência de um "senso comum teórico" na prática dos juristas, um núcleo de saberes jurídicos considerados científicos e, portanto, purificados de todas as formas de subjetivismo, mas que, na realidade, formam um conglomerado de afirmações carregadas de ideologia. Em suma, o senso comum teórico dos juristas constitui-se como um consolidado de crenças que se julgam caracterizadoras de uma episteme a respeito do Direito, mas que, na verdade, não passam de uma doxa disfarçada.

\footnotetext{
${ }^{11}$ Ainda não há publicações do autor, no mercado editorial, para divulgar essa nova proposta. Contudo, é possível conferir um pouco sobre o "materialismo mágico", projeto ainda embrionário, no blog do autor: http://luisalbertowarat.blogspot.com
} 
A presença do senso comum teórico na ciência jurídica revela a impossibilidade de se produzir um conhecimento neutro a respeito do Direito. Assim, a partir da obra de WARAT, em especial da noção de "senso comum teórico", pretende-se problematizar filosoficamente a questão da (im)possibilidade da neutralidade na prestação jurisdicional.

É importante destacar que o pensamento de WARAT está inserido num contexto pós "virada linguística" e de crítica da razão moderna, e disso decorre um interesse especial na sua obra. O reconhecimento da natureza linguística do discurso científico e de que o mundo se revela através da linguagem impôs uma mudança paradigmática na filosofia, que rompeu com o modelo clássico pelo qual se compreendia o processo de conhecimento, ou seja, com a chamada "filosofia da consciência". Segundo esta, sujeito cognoscente e objeto cognoscível seriam realidades absolutamente separadas, e o ato de conhecer significaria a representação, na consciência do sujeito, das características do objeto. Para a filosofia da consciência, portanto, o conhecimento somente seria possível através da abstração, operação segundo a qual o sujeito retira do objeto examinado todas as características que lhe são particulares, a fim de apreendê-lo e descrevê-lo em sua essência.

Ocorre que a filosofia da linguagem, conforme a configuração que recebeu no século XX, mostrou que sujeito cognoscente e objeto cognoscível não são realidades distanciadas, mas que se implicam mutuamente, e, de tal forma, o sujeito não apreende o objeto de maneira passiva, mas atribui-lhe sentido. Abalou-se, com isso, o conceito moderno de razão, que, marcado pela primazia do sujeito sobre o objeto, sustentava o caráter tão somente descritivo do conhecimento. A essa ruptura paradigmática da compreensão do ato de conhecer deu-se o nome de "virada linguística".

No âmbito da teoria do Direito, após essa transformação operada na teoria do conhecimento, impõe-se o reconhecimento do Direito como linguagem, como discurso. Por conseguinte, não se pode ignorar que, ao contrário do que se supunha, as normas não são imperativos prontos e acabados, dotados de um sentido unívoco que a hermenêutica jurídica conseguiria alcançar. Não é mais possível desconsiderar o fato de que não há uma verdade a ser descoberta pelo jurista (sujeito) ao analisar as normas ou os fenômenos jurídicos (objeto), mas um discurso a ser construído sobre a realidade estudada. Também não se pode esquecer que, se o intérprete do Direito contribui para a dação de seu sentido, resta comprometida a tão almejada objetividade na ciência jurídica.

Assim, adentrar (ainda que brevemente) na discussão sobre as repercussões da 
virada linguística para a filosofia do Direito e da crise da razão e da ciência modernas será imprescindível para mostrar que não há neutralidade no processo de julgar. E a obra de WARAT, autor que se debruçou sobre as implicações entre Direito e linguagem, parece contribuir de maneira precisa para essa tarefa. O presente trabalho, além de enfocar conceitos elaborados pelo referido autor, na década de 80 , não olvidará as ideias que ele desenvolveu nas fases posteriores, especialmente aquelas a respeito da crise da modernidade, que também servirão de pano de fundo para a reflexão a ser aqui apresentada.

Diz-se que o Direito deve servir de instrumento de resolução de conflitos. Contudo, nesta obra, a visão a respeito do sentido do Direito vai além: ele é entendido aqui como um instrumento não apenas de resolução de conflitos, mas de verdadeira transformação da realidade social, ou seja, dotado de sentido emancipatório ${ }^{12}$. E, para tanto, sua função não pode estar atrelada à manutenção do status quo viabilizada pela reprodução do senso comum teórico, principalmente no que concerne à atuação dos magistrados: torna-se necessário encontrar meios de romper com essa cultura jurídica standardizada, que influencia sobremaneira a atividade judicial. Questionar o paradigma da neutralidade do julgador parece colaborar nessa empreitada.

Convém destacar que neutralidade e imparcialidade no ato de julgar são posturas que não se confundem. Muitos autores utilizam essas expressões como sinônimas, como se representassem a mesma atitude na condução do processo, o que não é realidade. A primeira figura está associada a uma certa "assepsia" do magistrado, que estaria obrigado a despir-se de qualquer resquício de subjetividade no momento de proferir uma decisão, uma vez que o julgamento deveria se pautar exclusivamente por critérios extraídos do ordenamento jurídico. O magistrado neutro seria alheio ao litígio, indiferente ao seu desfecho, em especial às consequências do veredicto, que não lhe seriam atribuíveis, mas sim à legislação em vigor. Já a segunda figura é corolário do princípio do contraditório, e constitui-se em pressuposto para que a relação jurídica processual se instaure validamente $^{13}$. Trata-se da necessária distância que o juiz deve ter quanto aos interesses em

\footnotetext{
${ }^{12}$ Esse sentido pode ser defendido até mesmo pela via dogmática, já que a própria Lei Maior, ao definir os objetivos fundamentais da República Federativa do Brasil - e que, portanto, devem nortear o ordenamento jurídico e, sobretudo, a prática do Direito - estabelece as seguintes metas: construir uma sociedade livre, justa e igualitária; garantir o desenvolvimento nacional; erradicar a pobreza e a marginalização e reduzir as desigualdades sociais; promover o bem de todos, sem preconceitos de origem, raça, sexo, cor, idade e quaisquer formas de discriminação. (cf. art. $3^{\circ}$, caput e incisos, da Constituição Federal de 1988).

${ }_{13}$ CINTRA, Antônio Carlos de Araújo; GRINOVER, Ada Pellegrini; e DINAMARCO, Cândido Rangel. Teoria Geral do Processo. $9^{\text {a }}$ ed., São Paulo: Malheiros Editores, 1993, p.50.
} 
litígio. O magistrado parcial concederia maiores oportunidades de defesa a uma das partes, em prejuízo da outra, e interpretaria a lei em favor de uma delas, por estar pessoalmente interessado na questão. Sobre essa distinção, pontua LIDIA REIS DE ALMEIDA PRADO:

\begin{abstract}
A imparcialidade, bem como a suspeição do juiz, estão reguladas pela lei processual civil, tendo, assim, contornos bem traçados pelo Direito. Dessa forma, constituem figuras cuja existência é desejável no universo jurídico por possibilitar a igualdade das partes durante a resolução judicial dos conflitos, o que, aliás, é previsto pela Constituição Federal no artigo $5^{\circ}$, caput. Já, o dogma da neutralidade, herança do Iluminismo, relaciona-se com a idéia do magistrado formalista, exageradamente preso às leis e afastado dos desejos da comunidade $\mathrm{e}$ das características de seu próprio psiquismo. Assim, a adoção desse dogma constitui um desserviço ao principal objetivo da sentença, a realização da justiça. $^{14}$
\end{abstract}

Nesse sentido, a proposta deste trabalho é discutir o imperativo de neutralidade na prestação jurisdicional, principalmente a partir das implicações provocadas pelo desenvolvimento da concepção do senso comum teórico dos juristas, de LUIS ALBERTO WARAT, de modo a verificar as repercussões da imbricação entre Direito e linguagem na atividade judicial. A hipótese que se pretende discutir e comprovar é que, no processo de tomada da decisão, o juiz não é (e nem pode ser) neutro. Primeiro, porque lida com um saber jurídico acumulado (senso comum teórico) carregado de ideologia e subjetividade; segundo, porque, ao interpretar o Direito, contribui para a dação de seu sentido, construindo linguisticamente o objeto com o qual lida.

Reconhecer a impossibilidade de neutralidade na prestação jurisdicional não significa abrir mão da cientificidade com a qual o Direito deve ser estudado. Ao contrário, representa a tão necessária reconstrução das bases epistemológicas sobre as quais se alicerça a ciência do Direito. Significa trazer à tona uma realidade esquecida, que não pode mais ser recalcada como se não influenciasse a atuação judicial. Pretende-se mostrar, também, que o imperativo da neutralidade na prestação jurisdicional integra o senso comum teórico que contamina a atividade dos juristas, sendo, portanto, exigência a ser superada.

Para tanto, esta dissertação apresenta-se na seguinte estrutura: optou-se por uma divisão do texto em duas partes, com poucas subdivisões, a fim de se evitar uma compartimentação excessiva que contrariaria o próprio espírito da obra waratiana. Afinal, não seria conveniente apresentar de maneira cartesiana um pensamento assumidamente não linear.

${ }^{14}$ PRADO, Lidia Reis. Op. Cit., p. 37. 
Assim, na primeira parte deste trabalho buscou-se responder à seguinte indagação: como surge a exigência de neutralidade na prestação jurisdicional? Tendo em vista que esse dogma é corolário do princípio da divisão de poderes, que, por sua vez, constitui-se num dos fundamentos do Estado Moderno, o presente trabalho inicia-se com a caracterização do projeto filosófico da Modernidade e, por conseguinte, do Iluminismo, a fim de se compreender o processo histórico-cultural que foi determinante para a configuração do Estado Moderno liberal e, portanto, do princípio segundo o qual o juiz deve atuar de maneira neutra. Ainda na primeira parte, tentou-se mostrar como o projeto iluminista influenciou o pensamento científico moderno. Este, caracterizado pelas pretensões de objetividade e neutralidade, preconizou o distanciamento entre o observador e a realidade observada, o que trouxe consequências nefastas para a ciência e a prática do Direito, e corroborou a exigência de uma postura neutra da magistratura.

Uma vez delineadas as circunstâncias histórico-culturais que propiciaram a sedimentação do imperativo de neutralidade na prestação jurisdicional, a segunda parte deste trabalho constitui uma tentativa de desconstrução desse dogma a partir do pensamento waratiano. Num primeiro momento, buscou-se situar a obra de WARAT no contexto da Filosofia da Linguagem, de modo a evidenciar que o autor estrutura seu pensamento a partir de uma concepção renovada acerca da teoria do conhecimento, muito diferente daquela preconizada pela filosofia da consciência, a qual marcou profundamente o pensamento filosófico ocidental.

Sobrevém, então, a caracterização da proposta semiológica formulada por WARAT com vistas à construção de novos fundamentos epistemológicos para a ciência do Direito, dentro os quais se inclui o seu projeto de elaboração de uma semiologia do poder, que permitiria compreender a presença do poder nos discursos e dos discursos. Nesse momento, é também abordado o conceito de senso comum teórico dos juristas, que é central para o presente trabalho, porque revela a existência, na ciência e na prática do Direito, de uma série de representações, imagens, crenças e concepções que se apresentam como enunciados científicos mas que, na realidade, camuflam as diversas significações ideológicas que subjazem ao dito saber científico do Direito. A existência de um senso comum teórico dos juristas conduz ao questionamento da possibilidade de objetividade e neutralidade na ciência jurídica, bem como na atividade judicial.

E, por fim, partindo de todos os elementos anteriormente apresentados, em especial, do senso comum teórico dos juristas e dos achados da Filosofia da Linguagem, chega-se à 
seguinte questão: é possível cogitar-se de neutralidade na prestação jurisdicional se existe, na ciência do Direito, um conglomerado de representações ideológicas camuflado sob as vestes de enunciados científicos e se o magistrado, ao interpretar a norma, contribui para a dação de seu sentido? Responder a essa pergunta constitui o desafio do presente trabalho. 


\section{PARTE 1 - A GÊNESE DO IMPERATIVO DE NEUTRALIDADE NA PRESTAÇÃO JURISDICIONAL}

Para se compreender como nasce o imperativo de neutralidade na prestação jurisdicional é necessário entender, de um lado, como a Modernidade, e mais precisamente o Iluminismo, foi determinante para a consolidação do chamado Estado Moderno, fundado, sobretudo, na tripartição dos poderes e na concepção de que o juiz deve ser a “boca que pronuncia as palavras da lei”. De outro lado, é também imprescindível entender que influência o projeto iluminista exerceu na consolidação do pensar científico moderno, em que se estabeleceu, como condição de cientificidade, a exigência de uma postura neutra daquele que se dispõe a conhecer algo, e quais as repercussões disso no universo jurídico.

Os tópicos seguintes destinam-se às discussões sobre como o Iluminismo e a formação do Estado Moderno deram origem à exigência de neutralidade na prestação jurisdicional e como o ideal científico da modernidade também contribuiu para consolidar a necessidade de atuação neutra da magistratura.

\subsection{Modernidade, Estado moderno e divisão dos poderes}

A modernidade pode ser entendida como um conjunto de importantes transformações culturais, ocorridas na Europa, a partir do século XVII ${ }^{15}$, momento em que o homem passou a buscar explicações racionais para compreender a realidade, em reação ao dogmatismo das formulações medievais. Trata-se de um processo histórico que atinge o seu auge no século XVIII e que visava tornar concreto um novo projeto de civilização, fundado nas premissas do Iluminismo, movimento cultural pós-renascentista, que preconizava os valores da universalidade, do individualismo e da autonomia.

A principal marca do movimento iluminista era a ideia de que somente por meio da

\footnotetext{
${ }^{15}$ Nesta afirmação, toma-se por referência EDUARDO BITTAR, que, a partir de ANTHONY GIDDENS, afirma: “A modernidade, para designar o período histórico pós-renascentista, é a expressão do próprio espírito de um tempo ansioso pela superação dos dogmas e das limitações medievais. O século XVII é, portanto, o momento de eclosão de vários desses anseios, que, sob condições peculiares, permitiu o florescimento de uma nova dimensão social e econômica, especialmente na Europa, onde o espíritos da modernidade vem associado à idéia de progresso (BACON, DESCARTES)." E prossegue: "A modernidade, portanto, significa, numa perspectiva geográfico-temporal, '... o estilo, o costume de vida ou organização social que emergiam na Europa a partir do século XVII e que ulteriormente se tornaram mais ou menos mundiais em sua influência', como afirma Anthony Giddens.”. BITTAR, Eduardo C.B. O Direito na Pós-Modernidade. 2.ed. São Paulo, Atlas: 2009, pp. 34-35.
} 
razão seria possível ao homem tornar-se autônomo, senhor de si mesmo. Racionalmente, o indivíduo se livraria de todas as amarras que o impediam de ser livre, de fruir uma liberdade que lhe era inerente, própria de sua condição de ser racional. Essas amarras eram, principalmente, a natureza - que ele passaria a dominar através da razão, deixando de sujeitar-se a ela - e também as explicações mitológicas da realidade, que a falseavam, por serem dotadas de caráter metafísico. O processo de racionalização tornou-se, assim, a própria estrutura da modernidade.

O espírito que moveu o Iluminismo teve no alemão IMANNUEL KANT um de seus expoentes mais importantes. Em célebre texto escrito em 05 de dezembro de 1783, intitulado "Resposta à pergunta o que é esclarecimento", o filósofo conceitua o esclarecimento como sendo "a saída do homem de sua minoridade, pela qual ele próprio é responsável.” E continua:

\begin{abstract}
A minoridade é a incapacidade de se servir de seu próprio entendimento sem a tutela de um outro. É a si próprio que se deve atribuir essa minoridade, uma vez que ela não resulta da falta de entendimento, mas da falta de resolução e de coragem necessárias para utilizar seu entendimento sem a tutela de outro. Sapere aude! Tenha a coragem de te servir de teu próprio entendimento, tal é portanto a divisa do Esclarecimento. ${ }^{16}$
\end{abstract}

Assim, o esclarecimento (Aufklärung) significava esse abandono, pelos homens, do estado de minoridade, algo que dependeria deles próprios, da própria ousadia de enfrentar o processo de saída de um estado de "ignorância" para o de "conhecimento". Para atingir o esclarecimento bastaria a liberdade de pensar, o que justificava a luta contra todo o dogmatismo religioso e contra as explicações metafísicas a respeito do mundo, ou seja, ambições que correspondiam às principais divisas do Iluminismo.

A pretensão de alcançar o esclarecimento, portanto, foi o que levou a humanidade ${ }^{17}$ a abandonar os mitos e caminhar em direção à ciência. Para se tornarem esclarecidos, os homens deveriam pensar a partir da abstração, processo cognitivo através do qual se desconsideram as características acidentais do objeto estudado a fim de se atingir a essência de cada realidade examinada, para, então, formularem-se conceitos. Estes seriam exatos na medida em que representassem, com precisão, as notas essenciais dos objetos analisados. Vê-se que a elaboração de definições só é possível a partir da redução da

${ }^{16}$ KANT, Immanuel. Resposta à pergunta: O que é o Esclarecimento? Tradução de LUIZ PAULO ROUANET. Disponível em http://geocities.ws/eticaejustica/esclarecimento.pdf Último acesso em: 26 Mar 2008

${ }^{17}$ Faz-se, aqui, um uso generalizado do termo "humanidade", que é utilizado para referir-se à civilização européia ocidental. 
complexidade e significação da realidade examinada, que é viabilizada pela abstração. Entretanto, não é na modernidade que nasce a constatação de que o pensamento científico deveria ser obtido pela abstração. Já no pensamento de ARISTÓTELES estava presente essa noção, uma vez que ele atribuía a esse processo cognitivo a formação daquilo que compreendia por ciências teóricas, nestas incluídas a matemática, a física e a filosofia pura:

\begin{abstract}
'O matemático', diz ele, 'despoja as coisas de todas as qualidades sensíveis (peso, leveza, dureza, etc.) e as reduz à quantidade discreta e contínua; o físico prescinde de todas as determinações do ser que não se reduzem ao movimento. Analogamente, o filósofo despoja o ser de todas as determinações particulares (quantidade, movimento, etc.) e limita-se a considerá-lo apenas como ser' (Met., XI, $3,1.061$ a $28 \mathrm{ss}) .^{18}$
\end{abstract}

Convém ressaltar que a convicção segundo a qual o saber científico só é possível a partir da abstração está no cerne da teoria do conhecimento enquanto representação, a qual pressupõe a separação absoluta entre sujeito e objeto. Isso porque somente a partir da premissa de que o observador, no ato de conhecer, se encontra dissociado da realidade observada, é possível defender que o conhecimento resulta do processo pelo qual o sujeito representa mentalmente o objeto, qual seja, a abstração. Mais ainda, apenas com apoio nessas premissas é que a ciência moderna pode conceituar como verdadeiras as representações mentais que descrevem com precisão a realidade representada. O modo de pensar científico elegeu a objetividade como critério de verdade e exigiu do cientista o abandono de toda a subjetividade, porque somente a certeza da ausência de interferências pessoais garantiria a cientificidade da observação. Neutralidade e objetividade se tornaram a ordem do dia e deram sustentação às pretensões da condição moderna.

Em contraposição ao modo de vida medieval, na modernidade opera-se uma ruptura com a cosmovisão teocêntrica. Nesse momento, ocorre uma supervalorização das ciências naturais, que ofereceriam meios seguros (por exemplo, o método cartesiano) para se explicar os fenômenos da natureza.

Esse processo de racionalização só se torna possível a partir da hipervalorização da noção de indivíduo, segundo a qual, para ser livre e autônomo, o homem deve obter o máximo da razão. Essa concepção acarreta a desvinculação do indivíduo de seu grupo, pois o sujeito passa a receber um valor autônomo, independente dos demais da coletividade.

\footnotetext{
${ }^{18}$ ABBAGNANO, Nicola. Dicionário de Filosofia. Edição revista e ampliada. São Paulo: Martins Fontes, 2007, p.04.
} 
Surge, assim, um sujeito da história que destrói as metanarrativas que orientavam a compreensão da realidade.

Para lidar com essas questões, LUIS ALBERTO WARAT se vale de uma categoria que intitula "condição moderna", e que assim define:

\begin{abstract}
Os parâmetros fundamentais da condição moderna passam por valores ou visões de índole cognitiva, econômica, estética, mítico-religiosa, política, jurídica, ética, pedagógica, de sensibilidade, de linguagem, de amor, de autonomia e em torno das características do Estado. Todas essas manifestações não se deram ao mesmo tempo, nem no mesmo lugar. Se expandiram pela Europa, e pela recém conquistada América. Ao longo de vários séculos, grande fonte de determinação foi proporcionada pelo chamado Espírito das Luzes (o momento de maturidade da condição moderna) que produziu as idéias, envolventes, de possibilidade de uma marcha progressista da história, apoiada por três instâncias de determinação: a ciência, a moralidade e as artes. Essas instâncias encontravam seus fundamentos de validez na verdade, no dever e na beleza. Eram três fundamentos convergentes na manifestação do ideal (ideologia, fantasia ou como se queira chamar) de progresso. Eram três esferas que se juntariam para desembocar em uma anelada produção de perfeição (unidade plena). Era a subjetividade realizando sua máxima aspiração, coroada por uma universalidade alcançada pela via da razão (o grande ideal de humanidade expresso pela condição moderna). ${ }^{19}$
\end{abstract}

Reportando-se a CORnElius CASTORIADIS, WARAT afirma que já no termo moderno está presente uma espécie de narcisismo que lhe é intrínseco. Quando um determinado grupo de indivíduos, historicamente situado, se autoproclama moderno, fica implícita a intenção de retirar a importância de todo o desenvolvimento humano anterior. Somente se poderia falar de algo moderno diante daquilo que se considera ultrapassado. Essa caracterização tem um sentido simbólico forte e parece remeter a um futuro que nada mais seria do que um "presente eterno", um "dito para sempre”. Qualificar um tempo histórico como "moderno" parece excluir qualquer possibilidade de um devir.

É nesse mesmo sentido a reflexão de EDUARDO BITTAR quando aponta que o termo moderno não foi criado na modernidade, remontando aos antigos, que o utilizavam para designar os novos cristãos em oposição aos pagãos. E, baseado na obra de JÜRGEN HABERMAS, BITTAR afirma que o termo ganha força semântica, na Europa, a cada nova época histórica, e se consolida como vocábulo que designa o novo, o avançado, o atual e inovador, sempre se referindo ao presente, em oposição ao passado, ao antigo. Nas suas palavras, a utilização do termo moderno denota "uma preocupação em designar o que está nascente, o que está associado ao presente-que-deseja-o-futuro e, portanto, coube bem para

\footnotetext{
${ }^{19}$ WARAT, Luis Alberto. Introdução Geral Ao Direito - Vol. III - O Direito não estudado pela teoria jurídica moderna. Porto Alegre: Sergio Antonio Fabris, 1997, pp. 126-127.
} 
designar um período histórico que haveria de ser plantado sob a insígnia da liberdade e racionalidade" 20 .

E o autor prossegue:

É permitido mesmo, ao termo modernidade, associar uma variedade de outros termos que, em seu conjunto, acabam por traçar as características semânticas que contornam as dificuldades de se definir modernidade. Esses termos são: progresso; ciência; razão; saber; técnica; sujeito; ordem; soberania; controle; unidade; Estado; indústria; centralização; economia; acumulação; negócio; individualismo; liberalismo; universalismo; competição. Esses termos não estão aleatoriamente associados à idéia de moderno, pois nasceram com a modernidade e foram sustentados, em seu nascimento, por ideologias e práticas sociais nascentes e que se afirmaram como uma espécie de sustentáculo dos novos tempos, saudados com muita efusividade pelas gerações ambiciosas pela sensação (hoje tida como ilusória) da liberdade prometida pela modernidade. ${ }^{21}$

Para WARAT, a condição moderna era marcada pela busca da "verdade" e cultivava os valores da unidade e objetividade absolutas, tanto na ciência quanto na moral e nas artes. Fazendo referência a KANT, o autor lembra que esse filósofo foi responsável, com suas três grandes críticas (à razão pura, à razão sensível e ao juízo estético), por construir todo o arcabouço teórico que possibilitou o ideal moderno. A universalidade era a característica marcante nas formulações racionais buscadas nas três esferas. Na ciência, pretendia-se descobrir as leis absolutas e imutáveis que regiam a natureza; na moral, buscava-se fundar uma ética do dever universal (imperativo categórico), guiada pela razão; e, nas artes, buscava-se o sentimento do belo ideal, que poderia ser encontrado racionalmente, através de formas estéticas puras. Esses valores do racional, do ético e do belo deram os contornos de um projeto civilizatório que prometia alcançar o progresso e a autonomia do indivíduo, numa grande metanarrativa fundante que era, a um só tempo, emancipatória e especulativa. Nas palavras de WARAT:

No grande relato da emancipação, o Estado tomava a seu cargo a formação do
povo, o qual, sob o ideal do progresso, encaminhava-se para a autonomia e a
liberação. Era uma humanidade disposta a produzir um conhecimento universal
que conduziria à perfeição. No relato especulativo, a legitimação se constituía a
partir da convergência entre ciência, moral e política, cuja síntese permitira
constituir o espírito como sujeito de um delírio fundacional. ${ }^{22}$

Entretanto, segundo WARAT, esse ideal moderno era utópico: não passava de uma tentativa (frustrada) de mascarar o caos e a incerteza com os quais o ser humano nunca

\footnotetext{
${ }^{20}$ BITTAR, Eduardo C.B. Direito na Pós-modernidade. São Paulo: Atlas, 2009, p. 34.

${ }^{21}$ Idem, p. 35.

${ }^{22}$ WARAT, Luis Alberto. Introdução Geral Ao Direito - Vol. III - O Direito não estudado pela teoria jurídica moderna Porto Alegre: Sergio Antonio Fabris, 1997, p. 130.
} 
soube lidar. "Na racionalidade moderna não se aceitava o caótico, se queria encerrá-lo dentro de uma objetividade e uma conceitualidade fora do tempo"23. Também movido por esse anseio de ordenar a realidade, o pensamento científico, na modernidade, consolida-se em torno das pretensões de objetividade e neutralidade, tema esse que será tratado mais adiante. $^{24}$

SERgio Paulo RouAnet, autor que dedicou grande parte de sua obra ao tema da Modernidade, prefere distinguir entre Iluminismo e Ilustração ${ }^{25}$. Para ele:

O Iluminismo é uma ens rationis, não uma época ou movimento. Por isso sempre o distingui da Ilustração, que designa, esta sim, um momento na história cultural do Ocidente. Enquanto construção, o Iluminismo tem uma existência meramente conceitual: é a destilação teórica da corrente de idéias que floresceu no século XVIII em torno de filósofos enciclopedistas como Voltaire e Diderot, e de 'herdeiros' dessa corrente, como o liberalismo e o socialismo, que, incorporando de modo seletivo certas categorias da Ilustração, levaram adiante a cruzada ilustrada pela emancipação do homem. ${ }^{26}$

ROUANET sustenta, assim, que para se obter uma ideia do que foi o Iluminismo é necessário levar em conta os elementos da Ilustração, do socialismo e do liberalismo. Embora reconheça que essas categorias não esgotam os valores iluministas - que também remontariam à Antiguidade Clássica, ao Cristianismo, à Renascença e à Reforma protestante -, o autor afirma que a essência desses momentos históricos estaria compreendida na Ilustração.

Para RouAnET, as noções de autonomia, individualismo e universalidade, marcantes na Ilustração, também estariam presentes no socialismo e no liberalismo, e somente atentando para a roupagem que tais categorias receberam nesses três movimentos históricos é que seria possível formar um quadro do que foi o Iluminismo.

Após realizar essa análise no texto Iluminismo ou Barbárie ${ }^{27}$, ROUANET conclui que o projeto da modernidade, concebido no bojo do Iluminismo, pretendia assegurar a todos - homens e mulheres, independentemente de suas nações ou etnias - o direito de

\footnotetext{
${ }^{23}$ Idem, Ibidem, p. 134.

${ }^{24}$ Cf. item 1.2 deste trabalho.

25 Neste trabalho, contudo, será utilizada a concepção mais corrente dentre os filósofos e cientistas sociais contemporâneos, segundo a qual Ilustração e Iluminismo são termos correlatos. A despeito disso, a referência a esse consagrado cientista político brasileiro se justifica não apenas por ser referência no assunto, mas, principalmente porque sua obra permite uma melhor compreensão acerca da influência que o Iluminismo exerceu sobre o processo de formação do Estado Moderno, o que será necessário, mais adiante, para que se entenda como surgiu o paradigma da neutralidade na atuação dos magistrados.

${ }^{26}$ ROUANET, Sergio Paulo. Mal-estar na Modernidade. São Paulo, Companhia das Letras: 1994, pp. 1314.

${ }^{27}$ Idem, Ibidem, pp. 09-45.
} 
passar por um processo crescente de individualização que lhes permitisse alcançar autonomia plena.

O ideal iluminista de autonomia desdobrava-se em dois substratos: liberdade de agir e capacidade de se autodeterminar. O iluminismo ambicionava proporcionar a todos condições materiais e intelectuais de exercer, até o limite, a capacidade de autodeterminação. Esta seria inerente a todos os seres humanos, em virtude do atributo que os diferencia de todos os outros animais: a racionalidade.

Livre das superstições e das crenças religiosas, o homem alcançaria o seu máximo. Seria capaz de desenvolver o pensamento científico puro e uma arte dessacralizada, liberta de influências religiosas e dotada de potencial crítico. Conseguiria organizar-se socialmente de maneira autônoma, participando e conduzindo os processos decisórios que determinavam as regras de convivência. Também poderia obter, a partir da natureza, todos os bens necessários à sobrevivência e ao bem-estar, libertando-se das limitações impostas pelas condições naturais. Em suma, o Iluminismo visava à liberdade (de pensamento, política, econômica, cultural).

Para falar sobre Modernidade, ROUANET adentra na questão do intenso processo de racionalização da cultura que ocorreu nesse período. Para tanto, recorre à obra de MAX WEBER, estudioso que se debruçou sobre o tema de maneira bastante detida e aprofundada, especialmente na sua sociologia das religiões. Pautado, então, nos estudos de WEBER, ROUANET afirma que, num determinado momento na história do Ocidente, sobretudo a partir do século XVIII, operou-se uma aceleração do processo de racionalização da cultura europeia; e as mudanças sentidas nas esferas política, econômica e social delinearam um novo sistema referencial para a humanidade, que recebeu o nome de modernidade. Nas palavras do referido autor,

[...] se a modernização se define pela passagem de uma sociedade tradicional para uma sociedade pós-tradicional, a modernização é sem dúvida o objetivo principal da Ilustração. Ela não é outra coisa que uma investida maciça para abolir as velhas estruturas do Ancien Régime, substituindo-as por novas estruturas, mais racionais. ${ }^{28}$

Seguindo esquema proposto por HABERMAS, ROUANET separa em dois grandes blocos os diversos processos de racionalização enumerados por WEBER: a modernidade social, abrangendo o âmbito do Estado e da economia, e a modernidade cultural, que

${ }^{28}$ Idem, Ibidem, p. 124. 
compreenderia a ciência, a moral e a arte. Baseado nessa distinção, RoUANET conclui que, para se entender o ideário da modernidade, é necessário atentar para os processos de racionalização que ocorreram nos âmbitos econômico, cultural e político, na Europa do século XVIII.

Segundo o autor, a racionalização econômica possibilitou a dissolução do feudalismo e implementou as condições que deram surgimento ao capitalismo industrial, tais como a "formação de uma mentalidade empresarial moderna, baseada na previsão, no cálculo, em técnicas racionais de contabilidade [...]"29.

Concomitantemente, a racionalização cultural buscou o desencantamento do mundo, com a desconstrução das explicações sacralizadas a respeito da realidade e a separação dos valores contidos na religião em três esferas autônomas, quais sejam, a ciência, a moral e a arte. A primeira permitiu o acúmulo do saber e sua instrumentalização a favor do homem e do modo de produção capitalista, recém-configurado; a segunda, torna-se secularizada e tendente a encontrar parâmetros racionais de comportamento; e a terceira, por fim, caminha para formas cada vez mais independentes da religião, como a produção para o mercado, o que culmina com o nascimento de novos valores estéticos e a possibilidade de uso da arte como instrumento de crítica.

Soma-se a esse quadro a racionalização política, que viabilizou, segundo o autor

[...] a substituição da autoridade descentralizada pré-moderna pelo Estado absolutista e, posteriormente, pelo Estado verdadeiramente moderno, dotado de um sistema tributário centralizado, de um poder militar permanente, do monopólio da violência e da legislação, e de uma administração burocrática racional. A racionalização política desemboca na modernidade plena quando institucionaliza a dominação legal, legitimada pela crença em regras normativas e no direito dos governantes de exercerem sua autoridade em função dessas regras, distanciando-se assim da dominação tradicional, legitimada pela crença na tradição e da dominação carismática, legitimada pela devoção incondicional a líderes exemplares, especialmente heróicos ou especialmente virtuosos. ${ }^{30}$

Verifica-se assim que, dentre todas as pretensões da Ilustração, a de desencantar o mundo foi a mais importante, porque esteve no cerne e viabilizou não apenas o processo de racionalização no âmbito cultural, mas também nas esferas política e econômica.

O aspecto da Ilustração que mais interessa a este trabalho é o estímulo que houve, naquele momento histórico, à luta por autonomia política, ou seja, pela construção de um espaço para a atuação pública dos cidadãos através da criação de um sistema de garantias

\footnotetext{
${ }^{29}$ Idem, ibidem, p. 121.

${ }^{30}$ Idem, ibidem.
} 
que permitisse ao indivíduo opinar sobre os rumos da polis e não apenas sujeitar-se a decisões tomadas verticalmente.

A repulsa ao despotismo foi a maior herança deixada pela Ilustração no âmbito da política. Esse ideal motivou pensadores como RoUSSEAU e MONTESQUIEU a envidar esforços na tentativa de dar os contornos de um novo modelo de Estado, no qual a participação do indivíduo fosse não apenas valorizada, mas indispensável.

É nesse contexto que surge a doutrina da separação de poderes, dentre os quais deveria haver um equilíbrio de forças e uma neutralização recíproca. É nesse mesmo momento que surge a preocupação com o sistema judiciário, que não deveria conceder muita liberdade aos magistrados, sob pena de exercício arbitrário da função judicante.

Como é sabido, no Antigo Regime, o Estado encontrava legitimação no direito divino e nas tradições dos reinos, uma vez que os reis eram considerados herdeiros diretos de Deus. Valendo-se da categoria weberiana dos “tipos ideais”, RoUANET explica que essa forma de legitimação correspondia ao tipo ideal da dominação tradicional, que é rejeitada na modernidade em nome de formas mais racionais de legitimação.

O autor segue explicando que, na primeira metade do século XVIII, essa lógica de dominação começa a perder força, pois, com a consolidação da doutrina do Direito natural, em sua roupagem racionalizada, passou-se a exigir que a validade das leis e das instituições fosse demonstrada à luz da razão, através da comparação das normas criadas pelo homem com aquelas válidas por natureza e que eram perceptíveis racionalmente.

$\mathrm{Na}$ fase seguinte desse processo de racionalização política, já na segunda metade do século XVIII, surge uma nova epistemologia que privilegia a experiência em detrimento da razão abstrata, culminando com um desprestígio da concepção que defendia a possibilidade de existência de ideias inatas. Nasce, então, o paradigma da utilidade e, com ele, a concepção de que o Estado deveria servir à consecução do bem maior para o maior número de pessoas, o que somente seria possível a partir da realização da vontade do povo. Com isso, a legitimação estatal segundo a doutrina do Direito natural começa a ser questionada e tida como irracional, porque teria se "desviado do princípio da utilidade coletiva, promulgando leis que dividem, em lugar de unir, e por estimular paixões antisociais [...] em vez de incentivar as paixões apropriadas, capazes de acimentar os vínculos 
sociais" $"$.

Em meio a essas mudanças começa a ser concebida a ideia de que o Estado deveria ser aparelhado de modo a proporcionar o máximo de bem-estar para o maior número de pessoas e a de que, para atingir essa finalidade, ele deveria orientar-se a partir da vontade popular. Assim, após tornar-se uma concepção racionalizada e pautada no paradigma da utilidade, a legitimação estatal passa a decorrer das leis, que são a expressão concreta da vontade do povo. Com isso, completa-se a transição do Antigo Regime, em que prevalecia a legitimidade pela dominação tradicional, para o Estado Moderno, em que o paradigma é a dominação legal. Sobre o assunto, explicam LENIO LUIZ STRECK e JosÉ LUIS BoLZAN DE MORAIS:

[...] no Estado Moderno, a dominação passa a ser legal-racional, definida por WEBER como aquela decorrente de estatuto, sendo o seu tipo mais puro a 'dominação burocrática', onde qualquer direito pode ser criado e modificado mediante um estatuto sancionado corretamente quanto à forma; ou seja, obedecese não à pessoa em virtude de seu direito próprio, mas à regra estatuída, que estabelece ao mesmo tempo a quem e em que medida se deve obedecer. ${ }^{32}$

O modelo de Estado gestado na modernidade foi teorizado por diversos pensadores iluministas, dentre os quais se destacam MoNTESQUIEU, LOCKE e RousSEAU, todos empenhados em aparelhar esse novo Estado a fim de criar um jogo concertado de instituições que garantisse o exercício não arbitrário do poder e a autonomia popular. Afirma RouAnET:

\begin{abstract}
Quem melhor exprime a aspiração do Estado moderno, no sentido weberiano, é MALESHERBES, para quem não são os abusos particulares que devem ser abolidos, e sim o 'sistema da administração em seu conjunto', e que propõe, para alcançar essa metamorfose, três princípios: um novo conceito de lei, através de uma Constituição Escrita, que permitisse passar do reino da subjetividade ao da objetividade universal e necessária; o estabelecimento da representação popular, através das Assembléias Provinciais e sobretudo dos Estados Gerais, cuja convocação MALESHERBES é um dos primeiros a reclamar, catorze anos antes de sua reunião efetiva, em 1789; e a total publicidade das decisões executivas e judiciárias, para que o povo pudesse supervisionar as ações do Estado. Era o programa completo da dominação legal, proposto por um dos personagens mais significativos da Ilustração. ${ }^{33}$ (grifos nossos).
\end{abstract}

Tais concepções encontravam eco, por exemplo, em VOLTAIRE, para quem o mal do sistema político no Antigo Regime estava no Direito costumeiro, que relativizava as

\footnotetext{
${ }^{31}$ Idem, ibidem, p. 129.

${ }^{32}$ MORAIS, José Luis Bolzan de. STRECK, Lenio Luiz. Ciência Política e Teoria do Estado. $6^{\text {a }}$ ed. Porto Alegre: Livraria do Advogado, 2008, p. 41

${ }^{33}$ ROUANET, Sergio Paulo. Op. Cit., p. 130.
} 
leis, tornando-as variáveis de província em província e, portanto, defeituosas e injustas. As normas deveriam ser, na esteira de MALESHERBES, universais, aplicáveis a todos, sem distinção.

Como já foi dito, parece possível sustentar que a maior herança deixada pela Ilustração, no âmbito da política, foi o espírito de luta contra qualquer forma de governo considerada tirânica. Nesse sentido, ressaltam-se duas importantes constatações dos filósofos políticos da época:

A primeira delas é a concepção de liberdade política, que, nesse momento de contestação do Antigo Regime, foi definida como a possibilidade de os cidadãos se comportarem segundo os parâmetros estabelecidos pelas leis. Trata-se da consagração do princípio da legalidade, de fundamental importância para a consolidação do Estado Moderno liberal. Em contraposição ao modelo absolutista, a exigência de observância da legalidade estrita garantiu a todos os cidadãos previsibilidade no tratamento de suas condutas. A partir desse momento, as práticas permitidas e as proibidas não poderiam mais ser definidas segundo a vontade subjetiva do monarca, que também passou a se sujeitar às regras de Direito. Com efeito, a existência de um conjunto de leis que representam a vontade do povo e que se aplicam a todos, sem distinção, dificulta o abuso de poder pelo soberano. Não mais amparado por um sistema político que o permite governar segundo seus caprichos e interesses, ele fica impedido de conferir tratamentos diferenciados a situações semelhantes, como, por exemplo, aplicar penas diferentes a casos parecidos, como era usual na época. A esse respeito, pondera EDUARDO BITTAR:

\footnotetext{
De inspiração moderna, a idéia de um Estado de direito decorre exatamente de uma concepção liberal-burguesa de domesticação do poder pelo direito, na medida em que o princípio da legalidade se insculpe, especialmente após a Revolução Francesa, como uma espécie de libelo antimonárquico, o que é traduzido na tradição posterior como um libelo anti-arbítrio. Se há regras predeterminadas, se há um sistema de leis previamente dado, se existem normas que regulamentam a vida social, será segundo estas regras que haverão de se definir as condutas, seja de cidadãos (povo), seja de exercentes do poder (Estado).

É parte, portanto, do ideário do Estado moderno o princípio da legalidade. ${ }^{34}$
}

Verifica-se, assim, que o Estado Moderno liberal constitui-se enquanto ordem jurídica, o que deixa evidente o profundo valor atribuído à legalidade. Não por outro motivo os direitos civis e políticos foram a primeira classe de direitos humanos consagrada na história do ocidente, permeando, do início ao fim, a Declaração dos Direitos do Homem

${ }^{34}$ BITTAR, Eduardo. Op. cit., p. 74. 
e do Cidadão, escrita em 1793, logo após a Revolução Francesa. Aliás, essa declaração, além de eleger a liberdade como um direito natural do homem, chegou a defini-la, em seu artigo sexto, como sendo

[...] o poder que pertence ao Homem de fazer tudo quanto não prejudica os direitos do próximo: ela tem por princípio a natureza; por regra a justiça; por salvaguarda a lei; seu limite moral está nesta máxima: - 'Não faça aos outros o que não quiseras que te fizessem'.

Percebe-se, nesse conceito, a clara influência do jusnaturalismo em sua roupagem moderna, racionalista, bem como a alusão ao imperativo categórico formulado por Kant, que, como já foi dito, é considerado o expoente máximo da ideologia iluminista. Fica nítido, ainda, que, nesse contexto de surgimento do Estado Moderno liberal, o conceito de liberdade não guarda apenas um viés filosófico, mas também político.

É interessante observar que, como corolário do princípio da legalidade, nasce o princípio da anterioridade das leis e das penas, da igualdade e da segurança jurídicas, assim como a exigência de fundamentação das decisões judiciais, tudo como tentativa de se impor limites ao poder do soberano.

A segunda constatação dos filósofos iluministas, no âmbito da política, foi a percepção muito bem traduzida por MONTESQUIEU, no sentido de que "a experiência eterna mostra que todo homem que tem poder é tentado a abusar dele; e vai até onde encontra limites. Quem diria! A própria virtude tem necessidade de limites"35. Partindo da premissa de que todo governo que se prolonga no tempo tende a se tornar despótico a menos que encontre freios ao poder exercido, nasceu a doutrina da separação dos poderes e o sistema de freios e contrapesos. Nas palavras de SERGio Paulo RouAnet:

[...] foi diretamente em MONTESQUIEU que os revolucionários foram buscar a doutrina da separação dos poderes. (...). Para MONTESQUIEU, a separação dos poderes, baseada numa visão idealizada do sistema constitucional inglês, tinha como objetivo principal promover a limitação recíproca dos diferentes poderes, segundo mecanismo que mais tarde Madison chamaria de 'checks and balances ${ }^{36}$

SERGIO REZENDE DE BARROS faz interessante interpretação a respeito do sistema de freios e contrapesos desenvolvido por MonTESQUIEU. Segundo ele, embora a expressão cunhada pelo filósofo francês tenha sido "le pouvoir arrête le pouvoir" - cuja tradução literal, em português, seria "o poder pára o poder" -, a frase é geralmente traduzida por "o

\footnotetext{
${ }^{35}$ MONTESQUIEU, Op. cit. p 179.

${ }^{36}$ ROUANET, Sergio Paulo. Op. cit., p. 195
} 
poder controla o poder". SERGIO REZENDE afirma que algo de muito importante perdeu-se nessa modificação semântica. É que, para ele, a escolha do verbo "parar" e não “controlar”, por MONTESQUIEU, é muito significativa, pois denota uma referência, ainda que subliminar, à concepção mecanicista, muito em voga naquela época. $\mathrm{O}$ autor sustenta que, subjacente ao pensamento de MoNTESQUIEU, parece estar presente uma concepção do sistema legal e político do Estado Moderno enquanto sistema mecânico, que poderia ser equiparado ao sistema solar, de modo que "cada poder político tem sua órbita definida pelas leis, que exprimem relações necessárias, derivadas da natureza das coisas". Nas palavras de REZENDE:

É um sistema em equilíbrio, em que 'ninguém será constrangido a fazer as coisas às quais a lei não obriga, e a não fazer as que a lei permite' (Do espírito das leis, capítulo IV, livro XI). A lei é o sol - o centro - que ilumina a órbita dos poderes. Orbitam eles em torno dela, dentro de um sistema de inércia gravitacional, em que a força da gravidade de cada um atua sobre os demais, fazendo ir de acordo (aller de concert) uns com os outros, ficando cada qual em sua órbita de movimento, por efeito da gravidade de todos entre todos. Assim, a 'gravitação universal' dos poderes paralisa a exorbitância do poder. Se algum poder sai de sua órbita, sua exorbitância é paralisada por outro poder, que o pára e repara. ${ }^{37}$

O que o autor pretende mostrar é que a doutrina da separação dos poderes não foi criada para impedir a interferência mútua entre os poderes, como habitualmente se diz. Ao contrário, eles se autolimitariam naturalmente, pois esta condição de paralisação recíproca seria inerente ao próprio sistema político, uma vez que seu funcionamento seria regulado segundo uma lógica mecanicista. Aliás, essa percepção de que as coisas possuem uma natureza em si remonta ao jusnaturalismo moderno ${ }^{38}$, que parece ter influenciado a concepção de MONTESQUIEU a respeito das leis, pois ele as define como sendo "relações necessárias que derivam da natureza das coisas" ${ }^{39}$.

Após a Revolução Francesa, a doutrina da separação dos poderes foi consagrada no artigo 16 da Constituição de 1789, segundo o qual "uma sociedade em que a separação dos poderes não é determinada, não tem Constituição". Essa concepção influencia, desde então, o modo de organização dos Estados, e marca forte presença no constitucionalismo atual, inclusive no Brasil, que prevê, no art. $2^{\circ}$ de sua Carta Constitucional, que "são

\footnotetext{
${ }^{37}$ BARROS, Sergio Rezende de. Montesquieu e a Ideologia Mecanicista. São Paulo, 2009, p. 02 (mimeo).

38 "Se entre os séculos XVII e XVIII circulam idéias jusnaturalistas, que fundamentam o direito na própria natureza humana (natureza social, natureza racional...), em verdade, esses esquematismos racional-filosóficos estão a serviço da dessacralização das fundamentações imanentistas e metafísicas, fundadas no espírito prémoderno medieval. Era necessário refundamentar para que fosse possível recomeçar." BITTAR, Eduardo. Op. Cit., p. 62.

${ }^{39}$ BARROS, Sergio Rezende de. Op. Cit, p. 04.
} 
Poderes da União, independentes e harmônicos entre si, o Legislativo, o Executivo e o Judiciário"

O resultado da doutrina da separação dos poderes foi a consolidação de uma exigência de neutralidade do julgador, que em seu veredicto deveria espelhar as palavras da lei - ainda que o provimento, ao final, não parecesse justo aos olhos de seu prolator. Não era dado ao juiz colocar-se no lugar dos jurisdicionados, muito menos sopesar as consequências da lei no caso concreto, uma vez que tal função caberia ao Poder Legislativo: somente este poderia rever os comandos das normas, porque apenas desta forma restaria respeitada a vontade popular. Essa percepção é muito importante porque mostra como nasce, na modernidade, a figura do juiz neutro, que deve livrar-se de qualquer resíduo de subjetividade, sob pena de seu julgamento ser considerado exercício de puro arbítrio.

É importante destacar, contudo, que no contexto histórico de transição do Estado Absolutista para o Estado Moderno liberal, ou seja, no momento em que se buscou a superação de um governo que não garantia aos cidadãos sequer a liberdade política, o imperativo de neutralidade no exercício da função jurisdicional mostrava-se plenamente aceitável. Como já foi dito, estava claro para os teóricos iluministas que "tudo estaria perdido se o mesmo homem ou o mesmo corpo dos principais, ou dos nobres, exercesse esses três poderes: o de fazer leis, o executar as resoluções públicas e o de julgar crimes ou as divergências entre indivíduos" $"$.

Nesse contexto histórico, o Estado era idealizado segundo uma concepção mecanicista, em que os "três poderes deveriam formar uma pausa ou uma inação. Mas como, pelo movimento necessário das coisas, eles são obrigados a caminhar, serão forçados a caminhar de acordo" ${ }^{\prime 4}$. Por sua vez, o ordenamento jurídico era concebido enquanto um sistema que correspondia fielmente às aspirações do povo. Assim, era inevitável que o imperativo de neutralidade no exercício da judicatura parecesse, aos olhos dos teóricos modernos, decorrência lógica do sistema político por eles arquitetado.

No Estado moderno, após a conquista da tão almejada legalidade, tornou-se necessário construir um novo modelo estatal, aparelhado para assegurar a plena observância da Constituição. E um dos principais instrumentos utilizados nessa empreitada foi, justamente, a consolidação de uma magistratura que funcionasse como guardiã do

\footnotetext{
${ }^{40}$ MONTESQUIEU, Op. cit., p. 181

${ }^{41}$ MONTESQUIEU, Op. Cit., p. 188.
} 
ordenamento jurídico e que, portanto, atuasse no sentido de garantir que os comandos legais fossem respeitados e cumpridos, na sua literalidade. É o que justifica a expressão cunhada por MONTESQUIEU e já citada neste trabalho, qual seja, a de que o juiz deve ser "a boca que pronuncia as palavras da lei”, e que sintetiza bem as expectativas da época em torno da magistratura. Não por outro motivo, os filósofos de então preconizavam a seguinte máxima:

\footnotetext{
Não haverá também liberdade se o poder de julgar não estiver separado do poder legislativo e do executivo. Se estivesse ligado ao poder legislativo, o poder sobre a vida e a liberdade dos cidadãos seria arbitrário, pois o juiz seria legislador. Se tivesse ligado ao poder executivo, o juiz poderia ter a força de um opressor. ${ }^{42}$
}

Frise-se que não apenas o magistrado deveria concentrar-se no exercício do seu mister, como também os legisladores e os administradores deveriam centrar seus esforços unicamente nas funções específicas que lhes foram atribuídas, tudo em nome do bom funcionamento do Estado e da luta contra as formas de governo despóticas.

Entretanto, a pergunta que fica é: considerado o cenário político atual, em que se questionam a legitimidade das instituições, principalmente do Legislativo, a neutralidade do magistrado ainda resiste como um imperativo necessário ao bom funcionamento da máquina estatal? Essa pretendida neutralidade é mesmo possível? Tais questões serão abordadas nesta obra no momento oportuno. ${ }^{43}$

Um vez delineado o percurso histórico que levou ao surgimento da exigência política de neutralidade na prestação jurisdicional, passa-se agora ao exame de como a formação da ciência moderna, e em especial, da ciência do Direito, influenciou e consolidou o paradigma da neutralidade na atuação judicial.

\subsection{Modernidade, pensamento científico moderno e ciência do Direito}

A modernidade, no âmbito das ciências, trouxe as pretensões de objetividade, neutralidade e pureza. O saber científico constituiu-se sobre tais standards, que eram oferecidos como um porto seguro, como possibilidades de se garantir a coerência e a correção do raciocínio - um sistema autoexplicativo tido por racional, mas que, segundo WARAT, nada mais era que um sistema de crenças. Reduziu-se a complexidade do mundo

\footnotetext{
${ }^{42}$ MONTESQUIEU, Op. Cit., p. 181

${ }^{43}$ Vide item 2.2 do trabalho.
} 
em nome de uma obsessão pela ordem, pelo controlável. Ainda segundo a óptica desse mesmo autor, tratava-se de ilusões disseminadas como condição para o progresso, mas que, na realidade, camuflavam a impossibilidade de ordenação e controle do mundo fenomênico e ignoravam o papel do homem como inevitável partícipe na construção das realidades objetivadas.

WARAT sustenta que o desenvolvimento científico, na modernidade, consolidou-se em torno de mitos, o que garantiu, de maneira velada, a permanência do ideológico no campo das ciências. Para o autor, foi na modernidade que se constituiu o imaginário da linguagem científica, um discurso em que se estabeleceram objetivos impossíveis para a ciência, mas que, apesar disso, foram apresentados como as próprias condições de cientificidade, tais como neutralidade e objetividade. Esse imaginário constituiria um lugar específico de manifestação do ideológico, de certa forma escondido no interior das ciências, pois travestido de neutralidade. Seriam, segundo o autor, finalidades impossíveis atribuídas aos enunciados científicos:

[...] suprimir as pluralidades do real, pela ilusão de uma palavra sem ambigüidades (o ideológico se manifesta, aqui, como negação do caráter irremediavelmente plural da práxis e do saber); propor o artifício de dar um sentido final ao que é enunciado; estabelecer a possibilidade de uma gramática de produção sem componentes míticos; isolar a linguagem de seu tempo histórico, para representar a história; situar o erro como polifonia e a verdade como univocidade; impor a miragem do sistema da língua inventada como sistema do mundo. ${ }^{44}$

Assim, para WARAT, a partir dessa gramática mitificada, a forma de produção de conhecimento, na modernidade, constitui-se e consolida-se enquanto instrumento de poder. Paulatinamente, a ciência reduz-se à técnica e coloca-se a serviço daquele que detém condições materiais de torná-la factível. ${ }^{45}$.

O poder nos discursos científicos não precisa ter voz para manifestar-se. É no silêncio que se exprime, inclusive com maior eficácia. Esse imaginário mitificado das

\footnotetext{
44 WARAT, Luis Alberto. Introdução Geral ao Direito vol. II - a epistemologia jurídica da modernidade. Porto Alegre: Sergio Antonio Fabris, 1995, pp. 470-471.

${ }^{45}$ Cabe trazer à colação as ideias de Hilton Japiassu, que, ao tratar do tema, assevera que: "No dias de hoje, o desenvolvimento da ciência se encontra profunda e estreitamente vinculado ao devir do poder político, ou mais amplamente, do Poder. Mais do que nunca tem validade o slogan baconiano: Knowledge is Power = Saber é Poder. A tal ponto que, em seu rumoroso livro O homem unidimensional, o neomarxista HERBERT MARCUSE declara (década de 60): 'A ciência, por seu método mesmo e seus conceitos, projetou e promoveu um universo onde a dominação exercida sobre a natureza permaneceu ligada à dominação exercida sobre o homem. Toda mudança de orientação do progresso capaz de acarretar a ruptura desse vínculo fatal afetaria a estrutura mesma da ciência'. JAPIASSU, Hilton. Como nasce a ciência moderna - e as razões da filosofia. Rio de Janeiro: Ed. Imago, 2007, p. 201.
} 
ciências, repleto de significantes subliminares, faz com que o sentido histórico da ação de construir conhecimento seja esquecido, ignorado. Segundo WARAT, é esse distanciamento que possibilita à ciência consolidar-se como um dispositivo de poder. Essa compreensão do produto das ciências como algo divorciado das condições históricas de sua produção só é possível a partir do que esse referido autor denominou "mito da dupla racionalidade" Segundo ele, na modernidade, teria havido numa cisão artificial da racionalidade em dois diferentes níveis, quais sejam, “a (racionalidade) cotidiana, sem condições para apreender limpidamente a realidade; e a científica, que pretende através de procedimentos autocorretivos, ascender ao conhecimento imaculado do real". Essa distinção, que leva a crer na racionalidade científica como a única forma segura de compreensão do mundo explica WARAT -, acaba por renegar o fato de que todo conhecimento é um produto social e, portanto, sujeito a condicionantes históricos e políticos.

E o autor prossegue:

Assim começa, na modernidade, a discussão sobre as condições de possibilidade do conhecimento, fornecidas a partir de uma consciência (logo, um método), com poderes para pressentir a essência do real, da sociedade e da sua própria natureza. Como um grande paradoxo, a natureza do próprio conhecimento não teria nenhuma relação com o social e com a história. ${ }^{47}$

Segundo WARAT, o lugar da verdade, nas ciências, também é idealizado e faz parte desse imaginário anteriormente referido. Desde Platão, compreendeu-se a linguagem como instrumento que permitiria exprimir a essência do mundo observado, ou seja, captar as coisas em sua forma pura. Observando os objetos, o sujeito seria capaz de formular uma representação mental acerca deles, que, após, seria traduzida linguisticamente. A verdade seria encontrada na medida em que esse discurso representasse, com exatidão, os objetos examinados.

A ciência sempre teve a pretensão de alcançar a verdade, e esse sentimento intensifica-se na modernidade, como tentativa desesperada do homem de ordenar o mundo à sua volta. E com isso, nas palavras do autor "a verdade ficou, de um modo ou de outro, fora da história e da sociedade, como contemplação e desdobramento ordenado da consciência ou do discurso metódico do real" 48 . E arremata: "o espaço da verdade é assim

\footnotetext{
${ }^{46}$ WARAT, Luis Alberto. Introdução Geral ao Direito vol. II - a epistemologia jurídica da modernidade. Porto Alegre: Sergio Antonio Fabris, 1995, pp. 471-472.

47 Idem, ibidem.

48 Idem, ibidem.
} 
glorificado, mitificado autoritariamente". ${ }^{49}$

Na modernidade, portanto, a busca pela verdade científica significou uma tentativa de mascarar o caos do mundo real e, em última instância, livrar o homem da angústia provocada pela sensação de viver num mundo desordenado e imerso em contradições.

Uma explicação muito interessante, que vai ao encontro dessas constatações, é encontrada no livro Dialética do Esclarecimento, que foi escrito pelos alemães THEODOR AdORnO e MAX HoRKHEIMER, em 1930. Segundo os autores, a caminhada dos mitos em direção às ciências foi motivada, sobretudo, pelo medo. Essa conclusão parece encontrar respaldo quando se recorda o sapere aude kantiano, segundo o qual, para se tornar esclarecido, o homem deveria ousar conhecer.

Apesar do temor aos deuses, controladores da natureza indomada, não apenas o medo motivava a construção dos mitos. Os mitos não eram, simplesmente, narrativas historicamente construídas para o entendimento do mundo. Muito mais do que isso, consistiam no meio encontrado pelo homem para lidar com suas próprias angústias e incertezas, um modo de processar todo o desconhecido. Eram também uma forma de aquisição de saber que, ainda que apontada por muitos como irracional, pautava-se por outra concepção de racionalidade, muito mais afeita à intuição e ao plano do sensível.

Na mitologia não existe a intenção de dominação. O homem não quer, através dos mitos, dominar a natureza, mas lidar com o desconhecido, compreender melhor o mundo ao seu redor e a si mesmo. A mitologia não visa apenas a explicar a realidade, mas dar sentido a ela e à própria existência humana. Diante de um mundo que escapa ao homem e sobre o qual ele não interfere, os mitos surgem com a finalidade de acalmar o indivíduo que vive nesse universo aterrorizador. Assim, a criação dos mitos parece ter sido motivada muito mais pela necessidade do ser humano de se tranquilizar do que de explicar o mundo circundante.

Entretanto, observa-se que, da mesma forma com que o homem criou os mitos para afastar-se do medo e contornar a angústia sentida perante essa natureza incontrolável, ele, num passo seguinte, concebeu a ciência, motivado pelo mesmo medo que deu origem aos mitos. Nesse sentido, afirmam os autores:

Os deuses não podem livrar os homens do medo, pois são as vozes petrificadas do medo que eles trazem como nome. Do medo o homem presume estar livre quando não há mais nada de desconhecido. É isso que determina o trajeto da

${ }^{49}$ Idem, ibidem. 
desmitologização e do esclarecimento, que identifica o animado ao inanimado, assim como o mito identifica o inanimado ao animado. $\mathrm{O}$ esclarecimento é a radicalização da angústia mítica. ${ }^{50}$

Ocorre que a forma pela qual o homem lida com a "realidade" nos mitos é muito diversa do modo como ele o faz nas ciências. Ainda que a mitologia esteja ligada à magia e aos rituais, e que estes sejam uma tentativa do homem de interferir nos processos aos quais ele se sujeita, nos mitos ainda não há a separação entre sujeito e objeto que mais tarde se desenvolve a partir do pensamento científico. Isso porque ainda não estava presente, nos mitos, a noção de "representação". Quando se olhava para o Sol, não se via a representação de Apolo, mas realmente Apolo, conduzindo sua brilhante carruagem pelos céus. Em todos os outonos, quando as folhas das árvores começavam a cair, Perséfone realmente estava a ser raptada por Hades. Seu rapto não era simplesmente a representação do início do outono, mas de fato o início do outono. Havia uma identificação entre a narrativa mítica e os acontecimentos reais. A narrativa não era a mera "representação" de um determinado objeto, ao contrário do que acontece na ciência. Nesta, quando se faz uma experiência com um átomo, não se está lidando com um átomo em si, mas com o representante de uma categoria universal e inesgotável. E é justamente essa substitutividade que permite à ciência lidar com uma realidade "objetificada" e que dá margem à concepção segundo a qual, no ato de conhecer, sujeito e objeto são realidades separadas.

A questão parece ficar melhor elucidada se, nesse momento, procedermos a uma análise mais detida a respeito do sentido das representações míticas verificadas ao longo da história humana. Conquanto o termo "mito" receba, na modernidade, uma carga negativa, depreciativa, e passe a indicar tudo aquilo que pode ser apontado como ilusório, é possível ser compreendido de maneira mais positiva. Não parece correto afirmar que, na Antiguidade, os mitos eram despidos de racionalidade: apenas não se tratava da mesma racionalidade que se construiu na ciência. Assim, o resgate do sentido original do termo mito pode auxiliar na crítica do racionalismo e do positivismo que dele decorre.

MirCEA Eliade, importante mitólogo contemporâneo, aponta a tendência dos pensadores do século XX de tratar a questão dos mitos de forma diferenciada, segundo um enfoque bastante diverso daquele adotado pelos estudiosos, no século XIX. Para estes, o termo mito era compreendido como "fábula", "ilusão", "história falsa", numa total

\footnotetext{
${ }^{50}$ ADORNO, Theodor. HORKHEIMER, Max. Dialética do Esclarecimento. Rio de Janeiro: Jorge ZAHAR Editor, 1985, p. 26.
} 
degenerescência do sentido original do vocábulo, que, nas sociedades arcaicas, designava "histórias verdadeiras", "sagradas".

ELIADE afirma que, já na Grécia Antiga, percebe-se uma espécie de rejeição das formas mitológicas. Segundo o autor, XENÓFANES (565-470 a.C.) teria sido o primeiro a criticar a expressão mitológica das divindades utilizadas por HOMERO e HESÍODO, os quais, de certa forma, realizaram um esforço de sistematização dos mitos, tudo a evidenciar que "os gregos foram despojando progressivamente o mythos de todo o valor religioso e metafísico" e, também, que "em contraposição ao logos, assim como, posteriormente, à história, o mythos acabou por denotar tudo 'o que não pode existir",. 51

Percebe-se, assim, que a modificação do sentido semântico do termo mito, ao longo da história, reflete o processo de racionalização da sociedade ocidental, o que torna a discussão a esse respeito relevante para este trabalho.

A proposta de ElIADE é mostrar que compreender a acepção do termo mito, nos moldes em que o faziam as sociedades tradicionais, permite não apenas elucidar um período da história do pensamento do homem, mas entender melhor uma categoria que ainda se faz presente em nosso tempo. Isso porque o sentido original dos mitos era o de fornecer modelos para a conduta humana, bem como significação, sentido e unidade à existência.

Apesar de ter predominado, na modernidade, a acepção do termo mito que remete a "histórias falsas", nas sociedades em que a mitologia esteve ou está presente, faz-se uma diferenciação entre os mitos, que designariam "histórias verdadeiras" e os contos ou fábulas, estes sim referiam-se a "histórias falsas". A esse respeito, ELIADE pondera:

\footnotetext{
Ambas as categorias de narrativas apresentam 'histórias', isto é, relatam uma série de eventos que se verificaram num passado distante e fabuloso. Embora os protagonistas dos mitos sejam geralmente Deuses e Entes Sobrenaturais, enquanto os dos contos são heróis ou animais miraculosos, todos esses personagens têm uma característica em comum: eles não pertencem ao mundo quotidiano. Não obstante, os indígenas sentiram tratar-se de 'histórias' radicalmente diferentes. Tudo o que é narrado nos mitos concerne diretamente a eles, ao passo que os contos e as fábulas se referem a acontecimentos que, embora tendo ocasionado mudanças no Mundo (cf. As peculiaridades anatômicas ou fisiológicas de certos animais), não modificaram a condição humana como tal. ${ }^{52}$
}

Para as sociedades tradicionais, os mitos eram histórias verdadeiras porque, além de

\footnotetext{
${ }^{51}$ ELIADE, Mircea. Mito e Realidade. São Paulo: Ed. Perspectiva, 2007, p.08.

${ }^{52}$ Idem, ibidem, p. 15.
} 
narrar a origem do Universo e de tudo que nele existe, também explicavam porque o homem se transformou no que é: um ser mortal, que vive do próprio trabalho, em família e em sociedade. Ou seja, através deles é que se tornava possível compreender por que determinadas instituições existem.

Entretanto, nas sociedades arcaicas, a função dos mitos não se restringia a explicar a origem do mundo e das relações humanas. Mais importante do que isso, eles possibilitavam ao homem retornar a esse tempo fabuloso e vivenciar o momento em que tudo apareceu pela primeira vez. Esse retorno ao momento primordial da criação significava partilhar da presença dos Deuses, viver um tempo sagrado, miraculoso, em que se compreenderia a origem das coisas. Tratava-se, portanto, de uma forma de aquisição de conhecimento. Isso se dava através dos rituais, que não eram uma simples forma de rememorar esses eventos fabulosos, mas de reatualizá-los, ou seja, torná-los atos novamente, repetir aquilo que os Deuses ou os ancestrais fizeram ab origine. Nas palavras de ELIADE:

\begin{abstract}
'Viver' os mitos implica, pois, uma experiência verdadeiramente 'religiosa', pois ela se distingue da experiência ordinária da vida quotidiana. A 'religiosidade' dessa experiência deve-se ao fato de que, ao reatualizar os eventos fabulosos, exaltantes, significativos, assiste-se novamente às obras criadoras dos Entes Sobrenaturais; deixa-se de existir no mundo de todos os dias e penetra-se num mundo transfigurado, auroral, impregnado da presença dos Entes Sobrenaturais. Não se trata de uma comemoração dos eventos míticos mas de sua reiteração. $\mathrm{O}$ indivíduo evoca a presença dos personagens dos mitos e torna-se contemporâneo deles. Isso implica igualmente que ele deixa de viver no tempo cronológico, passando a viver o Tempo primordial, no Tempo em que o evento teve lugar pela primeira vez. É por isso que se pode falar no 'tempo forte' do mito: é o Tempo prodigoso, 'sagrado', em que algo de novo, de forte e de significativo se manifestou plenamente. (...). Em suma, os mitos revelam que o mundo, o homem e a vida têm uma origem e uma história sobrenaturais, e que essa história é significativa, preciosa e exemplar. ${ }^{53}$
\end{abstract}

A conclusão a que chega ElIADE vai ao encontro das observações formuladas por HORKHEIMER e ADORNO. Para eles, havia uma racionalidade intrínseca aos mitos, que se perdeu no percurso rumo ao esclarecimento.

Para desenvolver a questão da perda do potencial emancipatório da razão moderna, compreendida dentro da lógica da filosofia do sujeito, os autores de Dialética do Esclarecimento partem do exemplo dos rituais xamânicos, que se dirigiam sempre a coisas específicas (uma determinada serpente, a chuva que caía lá fora, uma pessoa enferma), e dos rituais tidos como mágicos, nos quais as máscaras usadas pelos celebrantes mudavam

${ }^{53}$ Idem, ibidem, p. 22. 
assim como mudavam os espíritos enfrentados. Existia, nessas circunstâncias, uma substitutividade específica $^{54}$, quer dizer, uma forma de tratar os acontecimentos como se fossem únicos e singulares.

Tanto a ciência quanto o mito se fundam na estrutura da repetição. Os experimentos científicos devem ser eternamente repetidos e chegar sempre ao mesmo resultado para serem considerados universais. De outro lado, nos mitos e na magia também está presente a repetição - dos acontecimentos e dos rituais. Entretanto, enquanto nos mitos existe essa substitutividade específica, a ciência lida com exemplares, com espécimes do material com que se realizam seus experimentos. São exemplo as cobaias de laboratório, que perdem o seu valor de indivíduos e são tidas como inesgotáveis, tratadas como um mero exemplar de uma categoria que não está em jogo no momento em que se realiza uma determinada experiência.

Esse descaso com o exemplar significa, segundo os autores, a perda do valor da "substitutividade específica" em nome do que denominam "fungibilidade universal", uma forma de compreensão da realidade que permite ao sujeito enxergar o objeto como algo destituído de valor. Assim, esse objeto torna-se manipulável, porque perdeu as características personalíssimas que faziam dele algo singular, possuidor das qualidades que faziam dele algo insubstituível.

Referindo-se à questão do sacrifício, prática bastante comum nas sociedades antigas, ADORNO e HORKHEIMER afirmam que, num determinado momento da história do homem, operou-se uma substitutividade nos rituais sacrificiais e, ao invés de se oferecer, por exemplo, o primogênito ou uma filha, passou-se a se oferecer um cordeiro ou uma cerva. Segundo eles,

[...] a substituição no sacrifício assinala um novo passo em direção à lógica discursiva. Embora a cerva oferecida no lugar da filha e o cordeiro no lugar do primogênito ainda devessem ter qualidades próprias, eles já representavam o Gênero e exibiam a indiferença do exemplar. Mas a sacralidade do hic et nunc, a singularidade histórica do escolhido, que recai sobre o elemento substituto, distingue-o radicalmente, torna-o introcável na troca. ${ }^{55}$

E arrematam:

[...] é a isso que a ciência dá fím. Nela não há nenhuma substitutividade específica: se ainda há animais sacrificiais, não há mais Deus. A substitutividade converte-se na fungibilidade universal. Um átomo é desintegrado, não em

\footnotetext{
${ }^{54} \mathrm{O}$ termo também é traduzido por "representabilidade específica".

${ }^{55}$ ADORNO, Theodor. HORKHEIMER, Max. Op cit., p. 22.
} 
substituição, mas como um espécime da matéria, e a cobaia atravessa, não em substituição, mas desconhecida como um simples exemplar, a paixão do laboratório.

ADORNO e HORKHEIMER também se referem à mimese como um precioso valor atinente aos mitos, que se perdeu nos caminhos rumos ao esclarecimento. $\mathrm{O}$ mimetismo está presente na natureza. Existem animais que imitam o comportamento de outros animais ou até mesmo o próprio ambiente para se proteger. É exemplo o bicho-pau, que imita a madeira para se confundir com o meio ambiente e escapar de seus predadores. Segundo VLADMIR SAFATLE ${ }^{56}$, ADORNO utiliza a noção de mimese a partir do conceito elaborado por Roger CAILlois, que a define como uma forma de defesa, uma certa tendência a perder-se no ambiente. É assim que, em Dialética do Esclarecimento, AdORNO e HORKHEIMER afirmam:

\footnotetext{
No estágio mágico, sonho e imagem não eram tidos como meros sinais da coisa, mas como ligados a esta por semelhança ou pelo nome. A relação não é a da intenção, mas do parentesco. Como a ciência, a magia visa a fins, mas ela os persegue pela mimese, não pelo distanciamento progressivo em relação ao objeto. $^{57}$
}

Dessa forma, a mimese característica do estagio mágico garante a inexistência de separação entre sujeito e objeto, de tal modo que não se poderia falar em objetificação, instrumentalização. Assim, nesse estado mimético, o homem está conciliado com a natureza.

Em Dialética do Esclarecimento, ADORNO E HORKHEIMER concluem que a ciência, para atingir a objetividade a que se propôs, teve de romper com as noções de mimese, e operar segundo a fungibilidade universal, provocando uma ruptura entre sujeito e objeto, na relação de conhecimento. Para os autores, a busca pelo esclarecimento implicou uma grave perda, que decorreu, justamente, da cisão entre sujeito e objeto, proporcionada pela razão moderna. Nos mitos não havia essa cisão. É claro que o conteúdo mítico, ou seja, as explicações em si a respeito da realidade, sempre foram extremamente singelas, precárias, mas não por isso despidas de racionalidade, como se pretendeu convencer na modernidade $^{58}$. Não se pode olvidar, assim, que, tanto o resgate do sentido original do

\footnotetext{
56 SAFATLE, Vladmir. Espelhos sem imagens: mimesis e reconhecimento em Lacan e Adorno. Trans/Form/Ação. Marília, v.28, n.2, 2005. Disponível em:

http://www.scielo.br/scielo.php?script=sci_arttext\&pid=S0101-31732005000200002\&lng=en\&nrm=iso Último acesso em 21.Nov. 2009.

${ }_{57}^{5}$ ADORNO, Theodor. HORKHEIMER, Max. Op cit., p. 25.

${ }^{58}$ É por isso que a tese central da obra Dialética do Esclarecimento é no sentido de que, já nos mitos estava
} 
termo mito quanto a reflexão a respeito da função que o pensamento mítico ocupava na organização das sociedades antigas, trazem consigo um forte potencial crítico da razão moderna. ${ }^{59}$

Um exemplo que ilustra bem a afirmação acima (a de que refletir a respeito da função original dos mitos pode auxiliar no questionamento dos limites da razão moderna) pode ser retirado da mitologia grega. Trata-se do mito de Prometeu e de Pandora, narrativa que é considerada como parte integrante dos "mitos do limite", tema recorrente em diversas civilizações antigas.

A partir de JUnITO DE SouZA BRANDÃo, importante mitólogo brasileiro, temos a seguinte versão do mito de Prometeu. Primo de Zeus, enganou-o por duas vezes a fim de ajudar os mortais. Num primeiro momento, dividiu um boi em duas porções, de modo a esconder as melhores partes do animal para dar aos homens. Ele fez com que Zeus escolhesse, por engano, a porção que continha apenas ossos, despertando sua fúria. Como castigo, Zeus privou os homens do fogo, e para reparar a situação, Prometeu se viu obrigado a enganar o poderoso primo pela segunda vez. Na interpretação de SoUZA BRANDÃO, a atitude de Zeus de privar os homens do fogo, significava, simbolicamente, privá-los da inteligência, imbecilizando-os. ${ }^{60}$ Foi então que Prometeu arriscou-se novamente e roubou uma centelha do fogo dos deuses e a deu para os homens. Ainda mais cheio de ira, desta vez, Zeus decidiu punir não apenas Prometeu, de forma exemplar, mas também a humanidade. Para esta última, enviou Pandora, mulher de irresistível beleza, que se tornaria a responsável por todos os males infligidos aos homens. Vale a pena transcrever a descrição feita por JUNITO DE SOUZA BRANDÃO:

Para perder o homem, Zeus ordenou a seu filho Hefesto que modelasse uma mulher ideal, fascinante, semelhante às deusas imortais. Pandora é, no mito hesiódico, a primeira mulher modelada em argila e animada por Hefesto, que, para torná-la irresistível, teve a cooperação preciosa de todos os imortais. Atená ensinou-lhe a arte da tecelagem, adornou-a com a mais bela indumentária e

presente o esclarecimento que se buscava e, de outro lado, o pensamento dito esclarecido resultou na estrutura mítica que se pretendia superar. Dizem os autores: "Do mesmo modo que os mitos já levam a cabo o esclarecimento, assim também o esclarecimento fica cada vez mais enredado, a cada passo que dá, na mitologia. Todo conteúdo, ele recebe dos mitos, para destruí-los, e ao julgá-los, ele cai na órbita do mito". ADORNO, Theodor. HORKHEIMER, Max. Op cit., p. 23.

${ }^{59}$ A despeito da menção à concepção positiva dos mitos, em respeito ao referencial teórico adotado neste trabalho, é necessário fazer uma distinção. Por diversas vezes, WARAT se utiliza do vocábulo mito para apontar ilusões presentes no campo do Direito e que decorrem da racionalização excessiva ocorrida nessa área. Para tanto, valeu-se do sentido negativo que a expressão mito recebeu, no que não se vislumbra qualquer problema. A perspectiva adotada pelo autor é mencionada nesta dissertação. Entretanto, não deixamos de fazer menção a essa outra perspectiva do termo mito, especialmente porque, como se disse, nessa distinção há um forte potencial crítico a respeito da razão moderna.

${ }^{60}$ BRANDÃ̃, Junito de Souza. Mitologia Grega. vol.01. São Paulo: Ed. Vozes, 1986, p. 167. 
ofereceu-lhe seu próprio cinto; Afrodite deu-lhe a beleza e insuflou-lhe o desejo indomável que atormenta os membros e os sentidos; Hermes, o Mensageiro, encheu-lhe o coração de artimanhas, imprudência, astúcia, ardis, fingimento e cinismo; as Graças divinas e a augusta Persuasão embelezaram-na com lindíssimos colares de ouro e as Horas coroaram-na de flores primaveris. . . Por fim, o Mensageiro dos deuses concedeu-lhe o dom da palavra e chamou-a Pandora, porque são todos os habitantes do Olimpo que, com este presente, "presenteiam" os homens com a desgraça!

Pandora foi dada de presente a Epimeteu (cujo nome significa "aquele que pensa depois"), irmão de Prometeu, para que com ela se casasse. Ela trazia consigo uma jarra de larga tampa, como presente de núpcias. Epimeteu, diante da beleza de Pandora, esqueceuse do conselho do irmão, de não receber nenhum presente vindo do Olimpo, e a aceitou. Foi quando Pandora, curiosa para saber o que continha a jarra que trazia, abriu-a, deixando escapar todos os males que passaram a afligir a humanidade, tais como as doenças, a fome, e a necessidade de trabalhar para sobreviver. Pandora fechou a jarra depressa, mas não a tempo de preservar os homens de quaisquer das desgraças que o objeto continha. Apenas ficou presa a esperança.

Quanto a Prometeu, o castigo foi terrível. Foi amarrado a pesados grilhões e tinha seu fígado devorado durante o dia por uma águia. Entretanto, o órgão se regenerava à noite e, assim, o castigo não teria fim, pois o animal voltava no dia seguinte para alimentar-se do fígado regenerado. JUNITO DE SOUZA BRANDÃo chama a atenção para o fato de que, na mitologia grega, o fígado era ligado à "sede de vida" e, portanto, era sempre alvo dos Deuses. $^{61}$

No livro A história da arrogância - psicologia e limites do desenvolvimento humano, o italiano LUIGI ZoJA, que, além de economista e sociólogo, possui também formação em psicologia analítica, tendo presidido a Associação Internacional de Psicologia Analítica (IAAP), traz interessante interpretação a respeito do mito de Prometeu.

Segundo ZOJA, numa análise mais desatenta, essa narrativa parece perder-se em meio a tantas outras, nas quais personagens míticos estavam fadados a seguir um destino já escrito, sem que houvesse qualquer possibilidade de evitarem os castigos divinos. Entretanto, fazendo-se uma análise mais detida, esse mito parece "anunciar um mundo no qual tudo isso sofrerá uma reviravolta, em favor de uma fé na liberdade do homem, no conhecimento e na busca de melhora". ${ }^{62} \mathrm{Na}$ visão desse autor, portanto, o mito de

\footnotetext{
${ }^{61}$ Idem, ibidem, p. 167.

${ }^{62}$ ZOJA, Luigi. A história da arrogância - psicologia e limites do desenvolvimento humano. São Paulo:
} 
Prometeu parece predizer a vinda da modernidade - aliás, o próprio nome desse herói grego parece conter essa ideia, pois significa "aquele que pensa antes".

A narrativa deixa em dúvida se o que movia Prometeu era uma desmedida generosidade em relação ao homem, ou o fato dele aceitar o seu destino como algo inelutável. Entretanto, ZoJA afirma que não se pode deixar de perceber, na atitude desse titã, e em especial na presença do elemento "chama", uma clara alusão à ideia de progresso. Nas palavras do autor:

\begin{abstract}
Diferentemente das dádivas materiais, toda forma de conhecimento, uma vez adquirida, não se perde mais. Do mesmo modo, exatamente quando represente antes de tudo a iluminação da mente, o fogo de Prometeu é irrevogável; Zeus, apesar de sua onipotência e de sua ira, não tenta retomá-lo: ele sabe, é evidente, que o fogo agora pertence ao homem. Em vez disso ele impõe, como punição eterna e divina, que seja roído dia após dia o fígado do culpado. A conquista do progresso - assim sugere a imagem antecipada mais clássica dentre as doenças psicossomáticas - está destinada a realizar-se em detrimento do corpo (....). ${ }^{63}$
\end{abstract}

Para ZOJA, é nesse momento que surge, na Grécia Antiga, a percepção que depois será determinante para a consolidação da cultura ocidental moderna, qual seja, de que "o céu foi forçado a dobrar-se a terra e nela aceitar, para sempre, a presença da fagulha divina" ${ }^{, 64}$.

Trata-se do momento definitivo, em que o homem passa a ter consciência de si próprio enquanto agente transformador do mundo e de que possui uma capacidade intrínseca que lhe permite o domínio da natureza. O homem passa a perceber-se como um ser autônomo, possuidor de um valor ético concreto, individual, dotado de uma existência que não se resume à pertença na coletividade em que habita. E, principalmente, como observa ZoJA, após a simbólica conquista do fogo, o homem "não se prostra mais, sentindo-se uma nulidade diante das divindades: uma parte do fulgor e do poderio de Zeus torna-se sua". 65

O autor prossegue e explica:

A história de Prometeu não é um episódio como tantos da mitologia grega, mas abre o caminho para a incorporação do divino; prepara o declínio da teologia através de uma espécie de teofagia gradual: uma deglutição do deus. Desse modo, o senso de autolimitação só pode desaparecer gradualmente. Se até agora o homem era uma nulidade, e devia evitar transformar-se em alguma coisa para não suscitar a ira de uma divindade potente e invejosa, esse limite se desvanece à

\footnotetext{
Axis Mundo, 2000, p. 132.

${ }^{63}$ Idem, ibidem, p. 135.

${ }^{64}$ Idem, ibidem, p. 135.

${ }^{65}$ Idem, ibidem, p. 135.
} 
medida que desaparece gradualmente o deus e também porque o deus desaparece por incorporação no homem.

Pouco a pouco, o homem sentirá agitar-se dentro de si a mesma onipotência caprichosa do deus, e esta então o autorizará a invejar seu próximo.

Reapropriando-se dessas pulsões, ele mata o mundo mítico e heróico que tiver a função de contê-lo, e que constituíra uma das primeiras mais elevadas formas de civilização. ${ }^{66}$

É importante salientar que o mito de Prometeu insere-se dentre os chamados "mitos do limite", que estão presentes em diversas civilizações, e que se caracterizam como narrativas destinadas a trabalhar o valor ético-moral do "comedimento". Ainda que segundo diferentes enredos, esses mitos tratavam de variados aspectos do caráter humano que poderiam levar a atitudes negativas e exageradas, tais como o excesso de vaidade, de audácia, de astúcia, dentre outros. Na mitologia grega, o descomedimento, representado pela chamada hýbris (arrogância, excesso), era sempre punido exemplarmente pelos deuses. Os indivíduos descomedidos, ou seja, aqueles que ultrapassavam os limites, eram vítima de Némesis (deusa da justiça divina, que pune com rigor).

Não foi diferente com Prometeu, que, ao mesmo tempo em que parecia cumprir um destino já selado, pode ser tido como precursor dos anseios iluministas. Prometeu enfrenta Zeus e devolve o fogo aos homens, ou seja, proporciona a eles as capacidades manuais e intelectuais que lhes garantiriam a sobrevivência. Esse fogo - que talvez não por coincidência seja um elemento associado à $l u z^{67}$-, parece simbolizar o uso da razão: Prometeu, ao restituir aos homens o uso do fogo, entrega-lhes a possibilidade de dominar a natureza, por meio do pensamento racional. Entretanto, o gozo dessa condição evolutiva tem um preço: a reboque dela, vêm todos os males que a humanidade ainda não havia suportado, como forma de punição pelo descomedimento, ou seja, pelo fato de o homem, agora possuidor do fogo olímpico, ter ultrapassado os limites da tênue linha que o separava dos deuses.

O mito de Prometeu parece mesmo predizer os percursos da modernidade. Assim como na narrativa mítica, o homem deixou de se prostrar diante do divino, o racionalismo moderno suprimiu a existência de sistemas referenciais para a conduta humana - seja a

\footnotetext{
${ }^{66}$ Idem, ibidem, p. 136.

${ }^{67}$ LUIGI ZOJA faz interessante afirmação sobre essa questão: “O fogo, principal dádiva de Prometeu, não é apenas o instrumento fundamental das transformações - para cozer os alimentos, para forjar as matériasprimas em objetos e, simbolicamente, os instintos em cultura e inteligência - mas é também luz. No momento em que toma posse do fogo, o homem começa a dispensar o Sol também para enxergar. Com o fogo prometéico, o homem não precisa mais voltar-se para o Céu à espera da iluminação. Esta imagem contém, profeticamente, seu futuro laico e cheio de curiosidade.”. Op. cit., p. 135.
} 
mitologia, seja a religião. E, preconizados os valores do individualismo e do relativismo ainda que se possa falar numa deturpação do sentido que a Ilustração originalmente lhes conferiu -, operou-se um certo enfraquecimento do sistema de normas morais, com o que o homem passou a praticar condutas descomedidas, sendo punido por isso. O fogo de Prometeu trouxe o progresso, mas, com ele, a dor. O mesmo verificou-se com a modernidade, em que a busca desmedida pela "luz da razão" provocou, ao contrário do que se pretendia, uma cegueira generalizada, que culminou com o surgimento de uma série de males que hoje a humanidade não sabe como conter. Exemplo disso é o elevado grau de devastação da natureza a que se chegou - num ritmo quase incontrolável e de consequências irreversíveis, como marca de um desenvolvimento científico pretensamente progressista, mas que renegou a tarefa de pensar a respeito de seu sentido. A esse respeito, eis a visão de EDUARDo BITTAR:

\begin{abstract}
O pragmatismo insaciável, que de tudo retira a aura, nascido desse processo, que se infla da idéia progressista, é o mesmo que alimenta os processos de acelerada destruição do mundo natural e exaustão do ambiente físico sobre o qual se lastreia a própria sobrevivência da humanidade. Em nome do progresso, conseguiu-se um regresso tão ilimitado que ameaça colocar a humanidade toda sob uma catastrófica e irreversível condição de barbarização. Mas essa advertência já havia sido feita por ADORNO E HORKHEIMER, quando afirmara: 'A maldição do progresso irrefreável é sua irrefreável regressão'. Com isso, o auge da civilização é sua própria aniquilação. ${ }^{68}$
\end{abstract}

Entretanto, é importante destacar que o Iluminismo, como se tentou mostrar no início deste capítulo, foi fruto de um intenso processo histórico que não possuía caráter destrutivo. Muito pelo contrário, pautava-se por uma supervalorização do homem, em contraposição a uma visão de mundo teocêntrica, mas com vistas à sua emancipação. Entretanto, operou-se uma exacerbação do racionalismo e, consequentemente, uma distorção dessas bases iluministas. E, ao contrário do que se buscava, a razão moderna, que se pretendia emancipatória, tornou-se excessivamente instrumentalizada e se transformou num dos mais eficientes e perversos artifícios de dominação e poder. A essa conclusão chega SERgio Paulo Rouanet:

Em nossos dias, podemos falar num mal-estar moderno, ou num mal-estar na modernidade. É forma contemporânea assumida pelo mal-estar na civilização. Como todas as outras formas de Unbehagen, ele se manifesta sob a forma de um grande ressentimento contra a civilização. Mas tratando-se de um mal-estar na modernidade, o ressentimento se dirige contra o modelo civilizatório que dá seus contornos à modernidade: o Iluminismo. O ressentimento antimoderno se transforma assim num ressentimento contra-iluminista. O mal-estar na modernidade é expressão psíquica do Contra-Iluminismo atual. Ele se traduz na

${ }^{68}$ BITTAR, Eduardo. Op. cit., p. 87. 
rejeição global de todo o projeto iluminista (...). É contra essa construção que se dirige a cruzada anti ou pós-moderna, não somente no plano das idéias como no das atitudes e práticas sociais. O Iluminismo institucionalizado é vivido como repressivo. O que não deixa de ser paradoxal. Afinal, o objetivo ostensivo do projeto iluminista era emancipatório. ${ }^{69}$

Porém, o que aconteceu para que a razão, compreendida como único atributo capaz de libertar o homem, fosse revestida de um caráter meramente instrumental, visando à adequação de meios a fins, quaisquer que sejam estes? Por que o projeto iluminista parece ter fracassado?

As respostas possíveis para essas perguntas são de diversas ordens. Contudo, talvez seja possível afirmar que o problema tenha surgido no momento em que o Ocidente optou por um modelo liberal de organização das relações sociais, fundamentado numa lógica de competição, que foi potencializada, na modernidade, pelo discurso de legitimação das ciências pelo desempenho e pela eficácia.

Na modernidade, a ciência nasce em oposição à tradição metafísica, mas se instrumentaliza em favor da burguesia e se separa do humanismo que lhe deu origem. $\mathrm{O}$ pensar científico, que via na razão a justificação de uma cosmovisão independente da metafísica, culmina atrelando-se a fins burgueses e se torna excessivamente tecnicista. Pela primeira vez na história ocidental, o conhecimento útil ganha respeitabilidade, pois interessa ao modo de produção capitalista, e a noção de técnica passa a substituir a ciência.

Como afirma HILTON JAPIASSU, "A ciência moderna nunca esteve totalmente separada da ideologia dominante na sociedade que tornou possível a sua emergência e progresso"70. Não se pode olvidar, portanto, o contexto histórico-cultural em que o pensamento científico se consolida, qual seja, o Iluminismo, e seus desdobramentos políticos, dentre os quais se destacam a Revolução Francesa e ascensão da burguesia ao poder $^{71}$. Isso porque, da mesma forma como o aparecimento do Estado moderno liberal

${ }^{69}$ ROUANET, Sergio Paulo. Op. cit., pp. 96-97.

${ }^{70}$ JAPIASSU, Hilton. Op. Cit., p. 273.

${ }^{71}$ Como é cediço, após o nascimento do capitalismo, a burguesia, detentora do poder econômico, passa a reivindicar o poder político, que, nas monarquias absolutas, estava concentrado nas mãos do clero e da nobreza. Na França, o cenário era especialmente propenso ao surgimento de uma crise que levaria à revolução, em razão dos extremados privilégios concedidos à nobreza e ao clero, como a desnecessidade de pagar impostos. A vontade da burguesia de ocupar os postos de poder, somada à insatisfação popular especialmente do operariado, que buscava melhores condições de trabalho e a derrocada dos benefícios concedidos às minorias que exerciam o poder -, forma um caldeirão de forças que consegue destituir o poder monárquico e consolidar uma nova forma de Estado, fundado na doutrina contratualista liberal, que tanto influenciou os revolucionários franceses, principalmente a partir das ideias de LOCKE. A esse respeito, cf. MORAIS, José Luis Bolzan de. STRECK, Lenio Luiz. Ciência Política e Teoria do Estado. $6^{\mathrm{a}}$ ed. Porto Alegre: Livraria do Advogado, 2008. 
visa a atender os fins e valores burgueses (a partir da descentralização dos poderes, antes concentrados nas mãos do clero e da nobreza), também a ciência moderna é instrumentalizada em favor da consecução dos objetivos da burguesia, ou seja, pelo ideal de aprimoramento das máquinas e de elaboração de técnicas capazes de otimizar o processo de industrialização e de comercialização das mercadorias produzidas. Com isso, o desenvolvimento científico adquire um caráter estritamente tecnológico, ou seja, preocupado com o conhecimento útil, com a criação de técnicas que atendem fins que lhe são exteriores, em geral, estabelecidos pelos sistemas econômico e político. Considerado esse contexto, JAPIASSU assevera:

\begin{abstract}
Ora, a partir do século XVI, o conhecimento deixa de ser uma atividade do otium (ciência pura) para converter-se num negócio. Em outras palavras, a ciência já nasceu vinculada ao poder político. Todavia, diferentemente dos imperadores gregos e romanos, que dirigiam a Cidade porque eram livres; diferentemente ainda dos reis medievais, que governavam em nome de Deus, a burguesia nascente, ao apropriar-se da racionalidade científica, não reivindica o direito, por natureza, ao governo da sociedade. Simplesmente toma e assume o controle de sua vida social graças ao poder que lhe confere o conhecimento científico fundado num sistema de racionalidade permitindo-lhe, mediante a utilização das máquinas e das técnicas, o domínio das coisas. E ao apoderar-se da racionalidade técnica e científica, a burguesia a torna cúmplice do poder. ${ }^{72}$
\end{abstract}

É interessante notar que, nesse contexto, a ideia de progresso, consagrada no Iluminismo como bandeira da luta pela emancipação do homem através da razão, transforma-se num anseio progressista reduzido à busca da realização dos fins capitalistas. As ciências adquirem, assim, um caráter pragmático, e a razão moderna torna-se um simples meio para alcançar determinados fins - estes, paradoxalmente, não necessariamente "racionais". Valia a descoberta, mesmo que isso significasse prejuízo para um núcleo de pessoas ou para o todo. A esse respeito, pontua o professor José BoLZAN:

\begin{abstract}
A transformação da razão emancipatória em razão instrumental começa a tomar corpo na medida em que a burguesia, por meio de seus ideais utópicos e do domínio dos meios de produção e de comunicação, foi subjugando as demais classes sociais. O uso do esclarecimento sob o pretexto de tornar o mundo habitável se efetiva pela repressão das demais dimensões da razão. 'O que os homens querem aprender da natureza é como empregá-la para dominar completamente a ela e aos homens'. (ADORNO; HORKEIMER, 1986, p.20). ${ }^{73}$
\end{abstract}

Assim, ao invés de emancipar o homem, preso ao obscurantismo do mundo em que predominavam as explicações teológicas, a razão moderna o prendeu de outra forma, na medida em que, motivada pela curiosidade humana ou por interesses políticos ou

\footnotetext{
72 JAPIASSU, Hilton. Op cit., pp. 273-274.

${ }^{73}$ BOLZAN, José. Habermas - Razão e racionalização. Porto Alegre: Unijuí, 2005, p. 30.
} 
econômicos escusos, tornou-se excessivamente instrumental e passou a objetivar o progresso sem limite das ciências, que abriram mão de qualquer fundamentação ética ou contextualização social de suas ações e pressupostos.

Eis a que MAX HorKHEIMER se referiu em seu texto $O$ Eclipse da Razão, um dos primeiros estudos sobre os desvios de percurso da razão, desde o momento em que esta foi eleita como referencial seguro das ações do homem até as consequências do racionalismo sentidas no século XX. Como afirma o autor:

Tendo cedido em sua autonomia, a razão tornou-se um instrumento. (...). A razão tornou-se algo inteiramente aproveitado no processo social. Seu valor operacional, seu papel no domínio dos homens e da natureza tornou-se o único critério para avaliá-la. Os conceitos se reduziram a síntese das características que vários espécimes têm em comum. Pela denotação das semelhanças, os conceitos eliminaram o incômodo de enumerar qualidades e servem melhor assim para organizar o material de conhecimento. (...). Os conceitos foram 'aerodinamizados', racionalizados, tornaram-se instrumentos de economia de mão-de-obra. É como se o próprio pensamento tivesse se reduzido ao nível do processo industrial (...). A ciência hoje, sua diferença de outras forças e atividades sociais, sua divisão em áreas específicas, seus procedimentos, conteúdos e organização, só podem ser entendidos em relação com a sociedade para a qual ela funciona. A filosofia positivista, que considera o instrumento 'ciência' como o campeão automático do progresso, é tão falaciosa quanto outras glorificações da tecnologia. ${ }^{74}$

Na mesma esteira, tem-se com EDUARDO BITTAR que

O processo de afirmação das sucessivas etapas do capital, do industrial ao financeiro, do nacional ao global, condicionou a própria identidade humana a um processo de alienação de sua própria natureza, em que o instrumento se converte em fim, e os meios operam independentemente do próprio ingrediente humano. Com a modernidade, abriu-se campo para a possibilidade de instrumentalização da razão, que agora se converte na inoperância de uma razão que tolera o convívio com a degradação humana, com a violência e a fome. ${ }^{75}$

E o autor completa:

A razão instrumental, que converteu a natureza em objeto da volúpia do progresso e do incremento do poder (Match), acessória da planificação capitalista, é a mesma que orienta e dá condições de expansão ao capital global contemporâneo, que, fundando ilusões de vida que se esgotam em consumo e posse, faz com que e respire atualmente uma atmosfera na qual se sente em suspensão o cheio de morte. ${ }^{76}$

Assim, a despeito de todo o avanço tecnológico obtido a partir do modo de pensar científico moderno, o que se verifica é que o projeto civilizatório da modernidade não conseguiu cumprir suas promessas. É diagnóstico comum a diversos pensadores

\footnotetext{
${ }^{74}$ HORKHEIMER, Max. O Eclipse da Razão. São Paulo: Ed. Centauro, 2006, pp. 30 e 66.

${ }_{76}^{75}$ BITTAR, Eduardo. Op. cit., p. 88

${ }^{76}$ Idem, ibidem, p. 91.
} 
contemporâneos a constatação de que a ciência, apesar de ter nascido com a proposta de responder às questões essenciais colocadas pelo homem, tem se tornado cada vez menos humana. Essa mesma ciência, que se pretendia esclarecedora porque livraria o homem das explicações míticas e religiosas acerca do mundo, acabou se transformando exatamente naquilo que ela buscava superar.

Curiosamente, ao mesmo tempo em que o surgimento da razão moderna provocou o desprestígio dos antigos sistemas referenciais que pautavam a conduta humana, percebese que a fé em Deus foi trocada pela fé na razão. E, paradoxalmente, como apontaram AdORno e HorkHEIMER, em sua Dialética do Esclarecimento, o querer libertar-se dos mitos criou um mito ainda mais poderoso: de que a ciência é o único "meio" de se atingir a verdade.

Essa, aliás, a divisa do positivismo, termo que foi empregado pela primeira vez no século XVIII, por SAINT-SIMON, para designar "o método exato das ciências e sua extensão"77. Posteriormente, a expressão foi aproveitada por AUGUSTO COMTE, que desenvolveu uma concepção filosófica caracterizada pela "romantização da ciência, sua devoção como único guia da vida individual e social do homem, único conhecimento, única moral, única religião possível"78, que ganhou muitos adeptos no século XIX. O positivismo fundava-se na concepção segundo a qual o método científico era o único caminho que poderia levar à verdade e, portanto, deveria ser estendido a todos os campos do saber humano. Assim, qualquer conhecimento não demonstrável através do método científico não teria valor e deveria ser rechaçado.

É importante relembrar, contudo, que foi DESCARTES quem se consagrou pela preocupação com a questão do método científico. Em 1637, ele publicou o Discurso sobre o Método, que marcou profundamente o modo de pensar da ciência. Partindo da premissa de que todos os homens possuem bom senso, ou seja, são dotados da faculdade da razão, que lhes permite julgar entre o bom e o ruim, Descartes indagou-se: por qual motivo as pessoas chegam a diferentes conclusões acerca de um mesmo problema? Para ele, a resposta a essa pergunta passava, necessariamente, pela questão do método: faltava aos homens um caminho seguro através do qual o pensar seria conduzido de forma a chegar sempre a respostas verdadeiras. Em outras palavras, uma via de acesso ao conhecimento correto, que poderia ser percorrida sem que se perdesse tempo com questões acidentais,

\footnotetext{
${ }^{77}$ ABBAGNANO, Nicola. Op. Cit., p. 909

${ }^{78}$ Idem, ibidem.
} 
que levariam ao erro e à contradição.

Imbuído desse espírito, formulou quatro regras que, se fossem seguidas rigorosamente, não poderiam levar a conclusões que não fossem verdadeiras. Seriam elas: a) duvidar de tudo: somente se poderia aceitar como verdadeiro aquilo que parecesse evidente; b) dividir os problemas em tantas partes quantas fossem necessárias para facilitar a sua solução; c) colocar os pensamentos em ordem, partindo dos mais fáceis até chegar aos mais complexos; e d) enumerar os problemas e proceder a uma revisão das análises e dos resultados encontrados, para certificar-se do não esquecimento de itens relevantes. $\mathrm{O}$ filósofo estava convencido de que, seguindo esse método, qualquer problema humano poderia ser resolvido. A partir de DESCARTES, a questão do método alcançou uma relevância tal no âmbito das ciências que esse autor passou a ser considerado por muitos como um dos fundadores do racionalismo moderno ${ }^{79}$. Segundo JAPIASSU:

\begin{abstract}
Para o grande público de sua época, a par das novidades intelectuais (sem fazer parte dos doutos), ele [Descartes] foi antes de tudo o filósofo dos animaismáquinas, dos pequenos corpos e dos grandes turbilhões. Foi o autor do Discurso sobre o método. Uma espécie de manifesto constitutivo do pensamento moderno e do espírito científico nascente. (...). É um legítimo herdeiro do renascimento, época na qual o homem toma consciência da autonomia de seu pensamento relativamente aos sistemas religioso e político. (...). Enquanto fundador do racionalismo moderno (fazendo o conhecimento proceder a princípios a priori: nada existe sem razão de ser, nada sendo de direito ininteligível), procede a uma verdadeira secularização da filosofia, após séculos de pensamento escolástico-religioso e de encantamento, pois faz da Razão o único fundamento de todo conhecimento possível. ${ }^{80}$
\end{abstract}

Após o advento do liberalismo econômico e suas consequências na configuração da ciência moderna, a máxima cartesiana do "dividir para conhecer" foi levada às últimas consequências. O especialista positivista, que já estava fechado no interior de seu método e preso a uma ilusão de verdade, passou a operar - talvez desapercebidamente, talvez não em função da lógica capitalista. Não se pode olvidar que pesquisas dependem de financiamento e que este passou a ser regulado por interesses mercantis. Com isso, a pretensão de alcançar o progresso perdeu sua vinculação a um sentido emancipatório e deu lugar à busca por desenvolvimento tecnológico estrito. $\mathrm{O}$ resultado do método cartesiano foi, assim, o oposto do que se esperava: a fragmentação da realidade conduziu à perda da noção de totalidade, e provocou alienação, não esclarecimento. Essa ciência

\footnotetext{
${ }^{79}$ Aqui é interessante destacar que o pensamento desse autor remonta ao século XVII, o que corrobora a tese anteriormente aventada, no sentido de que o Iluminismo, apesar de ter eclodido no século XVIII, foi fruto de uma série de transformações culturais que se desenrolaram desde o final da Renascença.

${ }^{80}$ JAPIASSU, Hilton. Op. Cit. pp. 99, 100 e 102.
} 
instrumentalizada, porque sedimentada sobre um racionalismo cego, que transformou especialização e profundidade em termos sinônimos, tornou-se cada vez mais limitada e inapta a julgar os próprios fins, o que favoreceu a sua apropriação pelo capitalismo.

No campo do saber tradicionalmente conhecido por "ciências humanas", as consequências do positivismo e do racionalismo exacerbado foram desastrosas: de um lado, passou-se a se utilizar os métodos das ciências naturais para o estudo de uma realidade totalmente diversa, na tentativa de se garantir a tal objetividade que marca o pensamento científico; de outro, a ciência tornou-se incapaz de resolver acerca de seus próprios fins, pois tal tarefa exigiria uma atitude valorativa, também rechaçada em termos científicos.

É interessante notar que essa exigência de objetividade encontra-se no cerne do modo de pensar ocidental, uma vez que a própria palavra teoria, que vem do grego Theorem, significa "visão", "janela”, ou seja o ato de colocar-se na tribuna do estádio para poder contemplar de longe os jogos e ter assim uma imagem panorâmica dos acontecimentos. Vê-se que o distanciamento da realidade por parte daquele que a observa é uma característica intrínseca ao próprio modo de pensar científico: ao cientista não cabem juízos de valor, pois apenas a libertação das impressões pessoais e de todas as formas de subjetivismo é que garantiriam a cientificidade de suas observações. Assim, a compreensão teórica da realidade, segundo WARAT, também corresponderia a uma atitude meramente “óptica” frente ao mundo. Nas palavras do autor:

\begin{abstract}
Examinando com certo cuidado o processo discursivo das ciências sociais, podemos notar muitas marcas de uma compreensão 'óptica' do mundo. Expressões como: ver, contemplar, evidência, idéia (que significa, originariamente, forma visível), ponto de vista, visão de mundo, etc., mostram às claras como o discurso das ciências sociais está impregnado de elementos dependentes de uma concepção 'óptica' do mundo. Inclusive a própria noção de teoria é filha da atitude 'óptica'. Ela provém do grego. Surge de um uso metafórico da expressão 'Theorem'. Os gregos empregavam essa palavra para referirem-se aos comentaristas das olimpíadas. Eles ficavam nas arquibancadas para opinar sobre os jogos do Olimpo. Curiosamente, esses personagens eram os únicos que não tinham nenhuma participação ativa nas competições. Só as viam. $\mathrm{O}$ 'theorem' tinha o vício da ocularidade que herdaram nossos cientistas instituídos. ${ }^{81}$
\end{abstract}

No campo da ciência do Direito, o ideal moderno de objetividade científica conduziu, por exemplo, à valorização da produção do saber estritamente dogmático e à tentativa de criação de uma Teoria Pura do Direito. Esse foi o desafio a que se propôs o

${ }^{81}$ WARAT, Luis Alberto. O Manifesto do Surrealismo Jurídico. São Paulo: Acadêmica, 1988, p. 22 
austríaco HANS KELSEN, o maior representante do positivismo normativista, cuja contribuição modificou em definitivo a forma de compreensão do fenômeno jurídico, ao menos no Ocidente. O modelo de ciência do Direito preconizado por KELSEN foi concebido sob a égide do conceito moderno de razão e parece corporificar a sua distorção. Disso decorre o interesse no estudo de sua Teoria Pura do Direito.

WARAT pode ser considerado um dos maiores especialistas em KELSEN, e muito embora tais estudos tenham se realizado nos idos dos anos 80, continuam extremamente atuais. No livro A Pureza do Poder, publicado em 1981, WARAT se propõe a uma análise profunda acerca do discurso kelseniano, mais especificamente, a respeito da proposta do jurista austríaco de depurar o fenômeno jurídico. E, para tanto, WARAT não busca criar um discurso alternativo, mas um contradiscurso, ou seja, uma crítica que se apresenta como tentativa de desconstrução que parte do interior do próprio discurso de KELSEN.

Nessa análise, WARAT percebe que a tentativa kelseniana de criar uma ciência do Direito, livre de quaisquer considerações de ordem subjetiva, ou seja, de acordo com o espírito cientificista que nasceu na modernidade, realizou justamente o seu oposto: tratouse de uma ciência tão desvinculada da temática do poder que acabou se tornando uma teoria suscetível de apropriação por qualquer sistema político. Segundo WARAT, a excessiva racionalização a que foi submetida a realidade jurídica, para que pudesse se tornar objeto de uma "Teoria Pura do Direito", fez com que a problemática do poder se instaurasse no interior dessa ciência com pretensões de pureza de maneira ainda mais intensa. E não se pode ignorar a repercussão dessa construção teórica acerca do Direito especialmente de seus deficits - sobre a atividade judicial. Vamos, na sequência, nos deter na análise waratiana da Teoria Pura do Direito.

Quando KELSEN avocou para si a tarefa de encontrar as bases metodológicas que permitiriam a construção de uma teoria acerca do Direito, viu-se obrigado a definir pressupostos e condições de possibilidade de um objeto autônomo para essa ciência. Influenciado pela concepção positivista de pureza metodológica, esse autor deixou claro seu objetivo de empreender uma análise axiologicamente neutra do Direito, de modo a evitar a subjetividade decorrente de considerações de ordem valorativa e, assim, garantir a cientificidade de seus achados. Para tanto, ele se absteve do exame do conteúdo concreto das normas, pois, do contrário, teria que lidar com valores, elementos tidos por ele como metajurídicos. Em razão disso, questões como justiça e legitimidade das normas jurídicas não poderiam constituir preocupação da ciência do Direito. A esse respeito, WARAT 
pondera:

Para KELSEN, a autonomia da ciência jurídica requer a sua libertação de todos os elementos que lhe são estranhos; a Ciência do Direito deve apenas pretender construir um conhecimento que tente responder às questões do 'que é' e 'como é' o Direito, sem procurar explicá-lo, transformá-lo, justificá-lo, nem o desqualificar a partir de pontos de vista que lhe são alheios. Essa é a exigência metodológica fundamental que nos define o sentido de pureza. (...). Nesse contexto de purificação, não pertenceriam ao campo temático, precisamente determinado como jurídico, as questões vinculadas à produção ou ajuizamento das normas jurídicas. Estas constituem problemas que devem situar-se no âmbito da Política Jurídica. ${ }^{82}$

É importante deixar claro que KELSEN jamais negou a necessidade de o Direito preservar seu aspecto ético e axiológico. Contudo, ao elaborar uma teoria do Direito com pretensões de cientificidade e, principalmente, por sustentar que a análise desses aspectos valorativos comprometeriam a objetividade de suas investigações, KELSEN concluiu que o problema da justiça das normas deveria ficar a cargo da Política Jurídica, razão pela qual o autor deixou de enfrentar tais preocupações em sua Teoria Pura do Direito,.

Outro motivo que justificava a tentativa kelseniana de "purificação do Direito" era a proposta de criar uma teoria que fosse apenas descritiva, e não prescritiva, ou seja, que se limitasse a descrever o objeto do Direito enquanto tal, sem indicar como ele deveria ser, a exemplo da doutrina do Direito Natural. Não se pode olvidar que os esforços de KELSEN para elaborar uma Teoria Pura do Direito nascem em contraposição ao jusnaturalismo, doutrina que se dizia em busca daquilo que seria o "justo por natureza", mas que, na realidade, pretendia legitimar certos conteúdos da ordem jurídica. Sobre o assunto, WARAT afirma que, para KELSEN:

\footnotetext{
Seria incorreto não perceber que, quando a Ciência do Direito pretende oferecer - apelando por exemplo, a um Direito justo - elementos para a determinação do conteúdos das normas jurídicas, encontra-se, indiretamente, produzindo Direito, indicando como este deve ser feito. (...). Daí, resulta que a Teoria Pura, despreocupada em tornar a Ciência do Direito uma arma poderosa a serviço de qualquer interesse político, enfrenta, decididamente, o Direito Natural, negandolhe qualquer valor teórico na produção do campo temático do saber jurídico. (...). O Jusnaturalismo constitui, frente a uma ciência normativa do Direito, uma doutrina sobre a ação política dos juristas. ${ }^{83}$
}

KELSEN pretendeu elaborar uma teoria do Direito que não se vinculasse a fins políticos específicos e, para tanto, entendeu ser necessário desvincular os enunciados dessa teoria de qualquer critério de justiça. É por tais razões que ele afirma que numa ciência

\footnotetext{
${ }^{82}$ WARAT, Luis Alberto. A Pureza do Poder. Florianópolis: UFSC, 1982, p. 27

${ }^{83}$ Idem, ibidem, p. 28.
} 
objetiva do Direito somente caberia discutir a validade das normas, pois esta categoria, sim, poderia ser aferida sem considerações axiológicas.

Verifica-se, assim, que a Teoria Pura do Direito cria o seu próprio objeto, qual seja, a ordem jurídica - um conglomerado de normas positivadas ordenadas segundo critérios lógico-racionais criados para viabilizar essa organização. O conjunto de normas positivas não se mostra, na realidade, como um todo organizado, mas se lhe impõe uma sistematização que permite a construção de enunciados científicos ao seu respeito. A construção do objeto da ciência do Direito dá-se segundo bases kantianas, conforme nos explica WARAT:

$\mathrm{Na}$ teoria kantiana, os dados a que uma teoria científica se referem carecem, em seu momento pré-científico, de significação. É mediante o trabalho de sistematização da ciência que eles adquirem significação. É mediante o trabalho de sistematização da ciência que eles adquirem sentido; fala-se, assim, de uma significação construída. De um objeto científico produzido. ${ }^{84}$

E prossegue:

\begin{abstract}
No caso da Ciência do Direito, as normas positivas de um grupo apresentam-se ao olhar do cientista, como um conjunto caótico que configura o Direito précientífico. Por isso, a Ciência do Direito constitui seu objeto, dotando a pluralidade caótica de normas positivas, no processo de sua sistematização, de uma totalidade de sentido. Na produção de uma teoria científica do Direito, apreendem-se os dados jurídicos como um objeto unitário; e esta unidade de sentido transforma as normas jurídicas positivas em uma ordem jurídica. ${ }^{85}$
\end{abstract}

Nota-se, portanto, um certo artificialismo com que se compreende a realidade jurídica na Teoria Pura do Direito. Entretanto, é justamente essa ficção que fornece as condições de possibilidade para que a ciência jurídica, nos moldes preconizados por KELSEN, tenha um objeto de estudo autônomo. Mais do que isso, é essa construção que permite compreender o Direito positivo como um sistema unitário, sem contradições. E frente a esse objeto harmônico e coeso, a postura do cientista do Direito seria, apenas, de levantar as questões teóricas e epistemológicas capazes de aprimorar ainda mais o sistema normativo, tornando-o cada vez mais imune a contradições. Exemplo clássico seria a busca incessante por métodos de integração de lacunas. Nesse sentido, a concepção de ciência do Direito preconizada pela Teoria Pura está muito próxima da chamada dogmática jurídica, com a ressalva de que esta última se debruça sobre os conteúdos das normas, enquanto a ciência do Direito se ocupa das normas positivas, mas apenas segundo o seu aspecto

\footnotetext{
${ }^{84}$ Idem, ibidem, p. 28

${ }^{85}$ Idem, ibidem, p. 29.
} 
lógico-formal.

Para construir um objeto teórico próprio para a ciência do Direito, KELSEN fundou sua teoria no que WARAT denominou "postulado de pureza metodológica", segundo o qual somente se alcançaria objetividade, na ciência do Direito, desvinculando-se saber jurídico de ideologia. Esse postulado constitui a espinha dorsal da teoria kelseniana, pois, ao evidenciar que o objeto de estudo desta não poderia conter fatores extrajurídicos, sob pena de restar comprometida sua cientificidade, fornece a condição de possibilidade de uma ciência pura do Direito. Com base nessa premissa, KELSEN poderia garantir, de um lado, que sua teoria não se constituiria num discurso destinado a influenciar a produção normativa; e, de outro, que os enunciados da ciência jurídica não seriam influenciados pela atuação política dos órgãos judiciais ou legislativos.

Assim, a partir do postulado de pureza metodológica, KELSEN também justifica a preocupação de evitar que outros fatores alheios à ciência do Direito a afetassem, especialmente aqueles advindos de outros campos do saber também preocupados em analisar o fenômeno jurídico, mas segundo outros métodos, como a sociologia, a psicologia, a ética e a teoria política. Para ele, esses outros conhecimentos acumulados, principalmente a Política Jurídica, estariam preocupados em enunciar o Direito ideal, ou seja, o Direito tal qual ele deveria ser, sempre aparados em alguma ideia de justiça ou preocupados em solucionar problemas sociais concretos. Entretanto, se se pretendia realmente produzir um saber estrito sobre o Direito, este deveria levar em conta o Direito real, tal como positivado, ocupando-se apenas de compreendê-lo estruturalmente. Assim, o objeto da Teoria Pura não poderia estar vinculado a nenhum critério de Justiça. Afirma WARAT:

\footnotetext{
Nesta perspectiva, a teoria Kelseniana nega-se a fornecer, a qualquer interesse político, as ideologias por intermédio das quais a ordem vigente é legitimada ou desqualificada. O caráter científico do Direito se constitui a partir de seu caráter anti-ideológico, como única salvaguarda da objetividade (outra idéia do neopositivismo). A tendência anti-ideológica, diz Kelsen, coloca a Teoria Pura como a verdadeira Ciência do Direito. ${ }^{86}$
}

Assim, para esse autor, fica patente que KELSEN concebia a noção de ideologia enquanto "teoria do erro". O objetivo da Teoria Pura do Direito era construir uma ciência autônoma, que não pudesse ser atrelada a fins políticos e nem a ideologias específicas, porque isso significaria não apenas um afastamento do ideal de cientificidade, mas uma

${ }^{86}$ Idem, ibidem, p. 47 
forma de se falsear a realidade. O postulado de pureza metodológica era o cerne da teoria kelseniana, porque, na visão de seu autor, tal exigência garantia a descrição fidedigna da realidade jurídica.

Entretanto, como somente mais tarde se pode perceber, essa busca incessante por uma ciência do Direito pura, livre de quaisquer condicionamentos ideológicos fracassou. Isso porque, ao tentar relegar essa realidade, transformou-se exatamente naquilo que pretendia evitar: uma teoria passível de ser apropriada por qualquer ideologia e, portanto, apta a fundamentar qualquer ordem jurídica, independentemente de seu conteúdo, bastando que as regras lógico-formais que garantem sua unicidade fossem observadas. Na avaliação de WARAT, a tentativa de "purificar" o Direito não passou de uma ilusão:

\begin{abstract}
Parece-me que a proposta da Teoria Pura do Direito, partindo dos critérios epistemológicos do positivismo científico (...) acredita exageradamente que o ideal das ciências sociais se cumpre enquanto elas 'aproximam tanto quanto possível, os seus resultados, do ideal de toda ciência: objetividade e exatidão'. Esta não deixa de ser uma ilusão perigosa, ilusão que desloca efetivamente, ao nível de repulsa total, as funções sociais que toda ciência cumpre. E, nesta perspectiva, as pretensões de purificação ficam bastante enfraquecidas. ${ }^{87}$
\end{abstract}

Com efeito, em consequência do postulado de pureza metodológica que orientou a construção da Teoria Pura do Direito, operou-se um notável afastamento da ciência jurídica em relação às demais ciências, ficando aquela enclausurada e cingida ao exame da estrutura lógico-formal das normas. Não bastasse isso, por não se vincular a um sistema ético específico, a pureza do modelo kelseniano permitiu que ele pudesse ser colocado a serviço de toda e qualquer ideologia. Em última instância, portanto, o fato de a ciência do Direito não figurar como a seara "competente" para discutir aspectos como justiça e legitimidade tornou-se pretexto para que juízes aplicassem as leis sem se ater a esses aspectos, já que levá-los em conta seria uma atitude não científica. Nesse sentido, manifesta-se WARAT:

Em geral, pode-se dizer que KELSEN, em decorrência da concepção de ciência do positivismo, utiliza um sentido de ideologia que rejeita, como dado subjetivo e obstáculo do conhecimento, toda e qualquer doutrina axiológica. Opõe, assim, os enunciados científicos aos enunciados morais, recusando a possibilidade de entender, como racional, o conhecimento metafísico.

A idéia de KELSEN, exposta no parágrafo anterior, encontra-se bastante contestada, pois, negando-se a tematizar a significação ideológica, KELSEN favorece o papel ideológico do conhecimento jurídico. Um conhecimento é científico (crítico) quando consegue explicar as significações ideológicas. ${ }^{88}$

${ }^{87}$ Idem, ibidem, pp. 31-32.

${ }^{88}$ Idem, ibidem, p. 48. 
Na avaliação que Warat faz da Teoria Pura, KELSEN teria obtido resultados muito mais proveitosos e, talvez, alcançado sua pretensão de construir uma teoria descritiva do Direito, caso tivesse admitido o caráter ideológico que perpassa o discurso da ciência jurídica. A essa crítica retornaremos no momento oportuno. ${ }^{89}$

O que se quer deixar claro, neste momento do trabalho, é que o positivismo normativista foi concebido no bojo do projeto iluminista e parece corporificar sua distorção. Do mesmo modo que a razão moderna converteu-se numa razão instrumental e, portanto, passível de ser utilizada para justificar ações vinculadas a qualquer sistema referencial, operou-se a mesma distorção com o Direito. A tentativa kelseniana de definir, como objeto da ciência do Direito, a chamada "ordem jurídica", nada mais foi do que a tentativa de conferir ao fenômeno jurídico uma organicidade plástica, autoritária, porque instituída desde fora, verticalmente. Uma tentativa de forjar uma unicidade e coerência que não são próprias da realidade jurídica. Aqui vislumbra-se, claramente, a distorção do ideal da modernidade, que, buscando imprimir ao mundo uma ordenação que não lhe era característica, traduziu-se, no âmbito do Direito, na violência com que se tentou racionalizar o fenômeno jurídico.

Considerando-se a temática desenvolvida neste trabalho, é importante destacar dois aspectos distintos do legado da modernidade. De um lado, a formação do Estado moderno, a consolidação do princípio da legalidade e da doutrina da separação dos poderes levou ao surgimento da exigência de neutralidade na prestação jurisdicional. De outro, o intenso processo de racionalização das ciências culminou na tentativa de construção de um saber científico também neutro. Parecia ter-se encontrado a composição perfeita: se o juiz deve exercer o seu mister com neutralidade, então necessita ter à sua disposição um saber jurídico construído de forma objetiva. Somente assim a prática judicial poderia ficar livre da influência do subjetivismo do julgador.

Entretanto, tal formulação não resiste ao exame da realidade cotidiana dos juízes, que evidencia situação bastante diversa. O magistrado, apesar de ser obrigado a manter-se neutro, recebeu em suas mãos um conjunto de conhecimentos pretensamente científico, mas que, na realidade, é dotado de intensa carga ideológica, que é reproduzida, despercebidamente, a cada julgamento proferido. Trata-se de um aglomerado de crenças e valores que permeiam a construção do conhecimento jurídico, e que são propalados não

\footnotetext{
${ }^{89}$ Cf. página 85 e seguintes desta obra.
} 
apenas pelos juízes, mas pelos diversos profissionais do Direito, na sua prática cotidiana, sem que se deem conta. Assim, todos que contribuem para o processo de concretização do Direito - grupo esse que abrange não somente aqueles ocupados da prática jurídica, mas também os doutrinadores -, o fazem a partir desse conjunto de crenças e se tornam preciosas engrenagens de um silencioso maquinário de propagação da ideologia eleita como "verdade", além de partícipes de um processo que visa à manutenção do status quo. WARAT denominou esse núcleo ideológico, que subjaz à ciência do Direito e a prática dos juristas, de "senso comum teórico", tema esse que será tratado no próximo capítulo.

A partir dessas constatações, pretende-se enfrentar a seguinte questão: é possível cogitar-se de neutralidade na prestação jurisdicional em face de um conhecimento jurídico que se apresenta como dotado de objetividade, mas que, na realidade, não o é? 


\section{PARTE 2 - A OBRA DE LUIS ALBERTO WARAT E A BUSCA DE UMA NOVA EPISTEMOLOGIA PARA A CIÊNCIA DO DIREITO: REFLEXÕES QUE PERMITEM REPENSAR O PARADIGMA DE NEUTRALIDADE DA MAGISTRATURA}

\section{1. - A proposta de uma semiologia política e a identificação do "senso comum teórico dos juristas" como necessárias à construção de um saber crítico do Direito}

\subsection{1. - Situando a obra waratiana no contexto da Filosofia da Linguagem}

O pensamento de WARAT pode ser situado no contexto da ruptura que a Filosofia da Linguagem, conforme sua configuração no século XX, provocou na compreensão do ato de conhecer. Como principal expoente desse momento filosófico, destaca-se LUDWIG WitTGENSTEIN, cuja obra póstuma - Investigações Filosóficas - elevou-o à categoria de um dos mais importantes filósofos de nosso tempo.

WitTGENSTEIN ocupou-se, fundamentalmente, do problema da linguagem e do conhecimento. "Que é linguagem? Que é pensar? Qual a relação entre o falar e o pensar ? Que faz de um sinal físico algo que significa? Como se relacionam linguagem e pensamento ao real?"90. Essas foram, segundo MANFREDO ARAÚJO DE OLIVEIRA, questões sobre as quais WITTGENSTEIN se debruçou ao longo de toda sua obra, que é comumente dividida em duas fases.

$\mathrm{Na}$ primeira, cujo conteúdo encontra-se expresso no seu Tractatus LogicoPhilosophicus (1922), a linguagem aparece como provida unicamente de função denotativa. Ela é tida como relação não arbitrária entre designante e designado, através da qual seria possível retratar a essência das coisas e demonstrar a verdade do mundo. Esta, por sua vez, possuiria um caráter relacional, explicado pelo autor através de sua "Teoria da Figuração". WITTGENSTEIN constata que o homem processa a realidade por meio de figurações, ou seja, transforma o mundo em pensamento e, depois, em expressão linguística. A figuração do mundo dos pensamentos deveria ser idêntica à figuração do mundo real, de modo que a verdade seria encontrada através da correspondência exata

90 OLIVEIRA, Manfredo Araújo de. Reviravolta Lingüístico-pragmática na Filosofia Contemporânea. $3^{\mathrm{a} e d . ~ E d i c ̧ o ̃ e s ~ L o y o l a, ~ S a ̃ o ~ P a u l o: ~ 2006, ~ p . ~} 95$. 
entre a estrutura do pensamento e a estrutura da realidade.

MANFREDO ARAÚJO DE OLIVEIRA explica que para WITTGENSTEIN, na primeira fase de sua obra,

[...] as palavras têm sentido porque há objetos que elas designam: coisas singulares ou essências. Esses objetos são dos mais diferentes tipos, havendo mesmo objetos muito especiais, os fatos, as situações objetais, designados nas frases. A última forma dessa teoria no Ocidente é, exatamente, a teoria da afiguração como correspondência estrutural entre frase e estado de coisas, respectivamente, fatos, elaborada no Tractatus. A frase representa, por semelhança estrutural, o estado de coisas por ela referido. A teoria do Tractatus significa, assim, uma reformulação da teoria tradicional da semelhança entre linguagem e mundo. Já que a linguagem não passa de um reflexo, de uma copia do mundo, o decisivo é a estrutura ontológica do mundo que a linguagem deve anunciar. A essência da linguagem depende, assim, em última análise, da estrutura ontológica do real. Existe um mundo em si que nos é dado independentemente da linguagem, mas que a linguagem tem a função de exprimir. ${ }^{91}$

Em As Investigações Filosóficas (1930), revela-se a transformação radical dessa orientação. WiTTGENSTEIN percebe que a função denotativa é apenas uma das muitas possíveis funções da linguagem. A pretensão de seu Tractatus, de lançar as bases de uma linguagem perfeita, capaz de expressar o real com exatidão, agora é considerada absurda. Isso porque o autor conclui não ser possível chegar à essência das coisas, como buscava o essencialismo. O que permite ao homem nominar objetos são as semelhanças de famílias entre eles, que admitem classificações.

Para Wittgenstein, o grande erro da filosofia do Ocidente foi, justamente, pretender separar as coisas do todo, definindo seus limites, delimitando seu lugar no real. Ele observa que o significado das palavras não pode ser estabelecido de maneira definitiva, pois está atrelado ao seu uso. A linguagem passa a ser compreendida enquanto um agir humano, de modo que não pode ser considerada abstraindo-se a situação de fala. Alcançar o sentido das palavras torna-se possível apenas se observado o seu uso concreto no contexto comunicacional. Wittgenstein, na segunda fase de sua obra, dá-se conta, assim, do caráter intersubjetivo da linguagem. Esse é o ponto de virada que sua obra provoca na filosofia no que se refere aos moldes de compreensão da relação de conhecimento.

Na chamada filosofia da consciência, o ato de conhecer era concebido como uma relação entre sujeito cognoscente e objeto cognoscível, em que estes eram tidos como realidades separadas. O homem seria capaz de observar o mundo, compreendê-lo, para

${ }^{91}$ Idem, ibidem, p. 121. 
então traduzi-lo em expressão linguística. Essa concepção - que também pode ser designada como "semântica tradicional" - nasce com a filosofia platônica, e foi especialmente delineada no texto Crátilo, escrito provavelmente no ano de 388 a.C., em que os personagens Crátilos e Hermógenes discutem a essência da linguagem. O primeiro defende o chamado "naturalismo", segundo o qual cada coisa tem seu nome por natureza, de modo que seria possível chegar à significação das palavras através de seu som. O segundo sustentava o "convencionalismo", corrente para a qual a significação decorre do uso da linguagem. PlATÃo utiliza esse diálogo para sustentar uma posição intermediária entre os dois personagens, de tal modo que as palavras não seriam meras imitações dos sons das coisas - como queria o naturalismo -, mas uma forma de representar os objetos na sua essência. Tampouco se poderia cogitar de uma relação, de certo modo, arbitrária entre as palavras e as coisas - como sugeria o convencionalismo -, porque aquelas deveriam, necessariamente, reger-se pelos sentidos emanados destas últimas. Para PLATÃO, o homem primeiro aprende, através de seu intelecto, a essência das coisas para, num segundo momento, expressar seus achados através da linguagem. Conforme explica MANFREDO:

Para os gregos, o pensamento é concebido como uma espécie de visão, ou seja, a
visão intelectual, a contemplação do ser verdadeiro. O olho do espírito era capaz
de captar a ordem objetiva, a verdadeira ordem das coisas, e essa ordem
percebida era, por sua vez, a medida, a norma de retidão da linguagem. A tarefa
da linguagem consiste, pois, na expressão adequada da ordem objetiva das
coisas. ${ }^{92}$

Essa distinção entre $o$ ser e a linguagem acompanhou a filosofia ocidental desde o seu nascedouro e fez-se presente durante todo o seu desenvolvimento, que foi marcado pelos esforços de diversos filósofos no sentido de buscar aprimorar os sistemas de sinais. Acreditava-se que a eliminação das imprecisões da linguagem aumentaria as chances de êxito na tarefa de descrever, com objetividade, o mundo circundante. Entretanto, com o novo status conferido à linguagem, a partir da segunda fase do pensamento de WiTTGENSTEIN, o sujeito cognoscente (ou sujeito de fala) e o objeto cognoscível (ou aquilo sobre o que se fala) revelaram-se realidades indissociáveis. Percebeu-se que inexiste um mundo em si, desvinculado de seus observadores, pronto para ser descoberto e descrito em palavras, e que a linguagem é constitutiva da realidade e não um mero instrumento que permite a sua apreensão, como se existisse um hiato entre o observador e a coisa observada.

WiTTGENSTEIN operou uma quebra de paradigma, a partir do quê a filosofia da

${ }^{92}$ Idem, ibidem, p. 19. 
consciência foi cedendo lugar à filosofia da linguagem, num processo que veio a se denominar virada linguística. Se não é possível, através da linguagem, conhecer a essência das coisas, senão apenas atribuir às palavras sentidos que variam conforme o uso, concluise que o conhecimento é profundamente marcado pelo agir do sujeito, partícipe na construção dos objetos com os quais lida. Depois da virada linguística, não é mais possível ignorar o fato de que é o próprio homem, em seu agir cotidiano, quem constrói, linguisticamente, o mundo. Nas palavras de MANFREDO:

\begin{abstract}
WITTGENSTEIN desce às pressuposições epistemológicas desta posição: que o conhecimento é algo não lingüístico, uma tese que, à primeira vista, parece ser, de modo geral, comum à tradição, até mesmo à filosofia da consciência da modernidade. É exatamente essa pressuposição da teoria lingüística do Tractatus que agora é posta em questão: não existe um mundo em si independente da linguagem, que deveria ser copiado por ela. Só temos o mundo na linguagem; nunca temos o mundo em si, imediatamente, sempre por meio da linguagem (IF 101-104, 737, 389, 379, 384). Entidades, atributos, as próprias coisas se manifestam em seu ser precisamente na linguagem. (...). A linguagem não é um puro instrumento de comunicação de um conhecimento já realizado, é, antes, condição de possibilidade para a própria constituição do conhecimento enquanto tal. $^{93}$
\end{abstract}

Entretanto, não apenas nos escritos de WITTGENSTEIN se verifica a preocupação com os limites da linguagem e sua relação com o ato de conhecer. Quase simultaneamente, o suíço FERdinAND de SAUSSURE funda, na França, a semiologia, e o americano CHARLES S. PIERCE, a semiótica, ambas voltadas à compreensão dos signos e do sistema linguístico. E é se aventurando na semiologia que LUIS ALBERTO WARAT busca elementos para visualizar a relação entre Direito e linguagem, e construir um arsenal teórico que se propõe a contribuir para a compreensão do papel da ideologia no discurso jurídico.

Dentre as principais preocupações epistemológicas de WARAT, está a de elucidar os motivos pelos quais, na trajetória das ciências sociais, em especial na ciência do Direito, operou-se uma perigosa simplificação da realidade que foi tornada objeto de estudo. E, ainda, a de revelar como a sistematização do fenômeno jurídico em categorias científicas pretensamente neutras provoca uma redução da sua complexidade, e se constitui num poderoso instrumento de dominação e controle social.

Seu interesse no campo da linguística parece decorrer da aceitação do fato de que a realidade não pode ser conhecida senão através da linguagem, e que esta, por sua vez, reduz a complexidade das significações sociais ao tentar traduzi-las em conceitos. Segundo ele "podemos dizer que a linguagem da ciência traduz a complexidade significativa a uma

${ }^{93}$ Idem, ibidem, p. 127. 
complexidade conceitual, logicamente ordenada, porém significantemente empobrecida." 94 . Percebe-se, assim, a íntima relação entre o pensamento waratiano e o novo paradigma da teoria do conhecimento, estabelecido no âmbito da Filosofia da Linguagem.

WARAT concorda com WITTGENSTEIN quando este sustenta ser desnecessária a elaboração de uma linguagem especial para a ciência, a fim de se designar de maneira mais adequada a realidade estudada. Bastaria a essa tarefa a própria linguagem comum. Segundo WARAT, o processo de criação da linguagem científica é movido pela pretensão de sistematização dos conhecimentos obtidos, o que significa, em última análise, uma conformação artificial da realidade. Esse discurso racionalizado - que teria esse caráter por razões epistemológicas, ou seja, para ser aceito como científico - camuflaria os acontecimentos extradiscursivos que condicionam a sua gênese. Entretanto, WARAT chama a atenção para o fato de que, mesmo sufocados, tais condicionantes do discurso por ele desbordam, de maneira velada.

E o autor percebe que, situando a questão da epistemologia das ciências no bojo da teoria da comunicação e, mais precisamente, da semiologia, poderia construir um saber capaz desvelar esses condicionantes. É assim que ele lança as bases de sua proposta epistemológica para o Direito, que ele denominou "epistemologia das significações". Nas suas palavras:

\begin{abstract}
O novo ponto de vista epistemológico que busco poderia ser caracterizado, em oposição ao anterior, como teleologicamente significativo, posto que apontaria, em primeiro lugar, para o conhecimento das condições extra-discursivas que determinam a produção do discurso científico e que perduram nele como elementos meta-comunicados. Neste sentido cabe afirmar que a explicitação das condições que possibilitam a produção das ciências sociais evidencia a interrelação das forças forjadas de domínios de conhecimentos discursivos e extradiscursivos, e de sujeitos, como efeitos da política, da ideologia e das significações acumuladas. O pressuposto filosófico que deve sustentar a epistemologia das significações é semiológico, já que com ele se busca orientar a prática científica para um plano de análises que permita o conhecimento da interação social como acontecimentos significativos (discursivos e extradiscursivos). Desta forma seria possível intentar a análise da totalidade social como complexidade significativa. ${ }^{95}$
\end{abstract}

A epistemologia tradicional a que Warat se refere é aquela que predominou na modernidade, profundamente marcada pelo positivismo. Fundada numa concepção extremamente racionalista da realidade, ela se pretendia como uma espécie de teoria geral

\footnotetext{
${ }^{94}$ WARAT, Luis Alberto. Introdução Geral ao Direito, vol. II. Porto Alegre: SAFe, 2002, p. 306.

${ }^{95}$ Idem, ibidem, pp. 307-308.
} 
das ciências e como crítica da filosofia. Na epistemologia tradicional, entendia-se possível obter um discurso absolutamente objetivo sobre a realidade, a qual era compreendida segundo dicotomias profundas, tais como sujeito e objeto, verdade e erro, ciência e ideologia, doxa e episteme. Essas distinções teriam a função ideológica de mascarar os condicionantes do discurso científico.

É a essa epistemologia tradicional que se opõe a proposta waratiana de uma epistemologia das significações, na qual o saber científico englobaria todas as esferas excluídas pela visão clássica, principalmente a ideologia. A oposição ciência-ideologia perderia sentido ao se reconhecer que o "discurso científico encontra em sua gênese preconceitos, hábitos metafísicos, profecias, ilusões de transparência e noções apoiadas em opiniões, que refletem simplesmente as práticas espontâneas da comunidade científica"96.

Nesse momento, o que entra em jogo é o problema da verdade científica e, portanto, a questão da objetividade no conhecimento. Segundo WARAT, a tradição positivista se apoiava numa concepção do conhecimento a partir da "teoria do reflexo", em que o sujeito seria um agente passivo, que receberia as informações do objeto e elaboraria uma cópia fiel da realidade examinada. Nessa teoria estava fundada a concepção clássica da verdade enquanto objetividade, ou seja, a coincidência exata entre as características do objeto e o discurso que se faz sobre ele, escopo que somente seria alcançado a partir do distanciamento entre sujeito e objeto, condição para a observação neutra da realidade.

Nesse aspecto, fica mais clara a possibilidade de inserção das ideias waratianas no paradigma da Filosofia da Linguagem concebido após WiTTGENSTEIN. É que também para WARAT, a concepção do ato de conhecer fornecida pela teoria do reflexo sucumbe quando se o compreende a partir da teoria da comunicação. Como já se disse, para ele, a elaboração de conceitos a respeito do mundo reduz a complexidade da realidade, especialmente ao excluir elementos extradiscursivos que, apesar de presentes, deveriam ser eliminados ou reprimidos, em nome do ideal de cientificidade do conhecimento. Afirma o autor:

Do modelo clássico de objetividade se deriva uma concepção instrumental da
linguagem, que equivocadamente a considera como um veículo neutro, um meio
passivo, que relaciona a realidade social, cuja existência objetiva se aceita, com
uma consciência cognoscente. Conseqüentemente, a significação fica excluída
do discurso e da ação social, sendo apresentada como um fenômeno meramente
subjetivo e personalizado. A epistemologia tradicional, ao aceitar a teoria do reflexo, afirma que um

${ }^{96}$ Idem, pp. 311. 
enunciado é objetivo e é verdadeiro. E é verdadeiro quando corresponde aos fatos, o que quer dizer, se pode explicar como uma denotação neutralizada dos juízos conotativos. Surge assim uma condição semântica de significação, a partir da qual se aceita como significativos, unicamente, os enunciados reduzidos a uma dimensão denotativa unívoca. A condição semântica da verdade e da objetividade encontra seu fundamento no mito do referente puro. ${ }^{97}$

Em contraposição a esse modelo clássico, WARAT propõe um modelo pragmático da objetividade científica, ou seja, que considera o "lugar da fala" daqueles que proclamam o discurso científico. Ele passa a conceber a objetividade como recurso semiológico que expressa a inevitável relação entre as ações sociais e a produção de significações. Com isso, pretende mostrar que nada mais que decisões políticas estabelecem as fronteiras entre o imaginário e a realidade. A configuração de um campo epistemológico não é desinteressada: ela constitui uma forma de controle da produção dos discursos tidos como verdadeiros. Para ele, portanto, o problema da verdade é indissociável do problema do poder.

Nesse sentido, WARAT chama atenção para o fato de que o discurso considerado verdadeiro nunca provém de um emissor isolado. A produção de conhecimento ocorre no interior de uma comunidade científica, que compartilha hábitos linguísticos e crenças epistemológicas. Somente depois que esta avaliza um determinado discurso é que ele passa a ter credibilidade. Assim, é necessário pertencer ao que WARAT chamou de o monastério dos sábios para que o discurso pronunciado seja digno de ser considerado científico. A esse respeito, o autor pondera:

No caso da comunidade científica é impossível penetrar nela, converter-se em um de seus emissores autorizados, se não se fala (ao menos como ritual de iniciação) a língua oficial do Estado, se não se aceitam os 'padrões epistemológicos' que a cultura científica dominante impõe. Neste sentido, a verdade é sempre uma palavra do Estado. Ele exerce sobre as verdades uma tutela sutil, latente, não declarada, da qual é muito difícil escapar. ${ }^{98}$

É inevitável concluir que, somente a partir do paradigma da filosofia da linguagem, considerada a virada linguística operada na teoria do conhecimento, após a obra de WITTGENSTEIN, é que WARAT poderia chegar a tais conclusões.

Convencido, assim, de que somente o estudo da relação entre Direito e linguagem possibilitaria o enfrentamento do problema da presença camuflada da ideologia no discurso

\footnotetext{
${ }^{97}$ Idem, ibidem, p. 312 e 316.

98 WARAT, Luis Alberto. Introdução Geral ao Direito vol. II - a epistemologia jurídica da modernidade. Porto Alegre: Sergio Antonio Fabris, 1995, p.69.
} 
jurídico, WARAT desenvolve seus estudos no campo da semiologia e propõe a criação de uma "semiologia política" ou "semiologia do poder": um saber semiológico que teria o propósito de revelar o poder nos discursos e dos discursos. Tal projeto começa a ser desenvolvido no final dos anos 70 e para que se compreenda bem essa proposta - que possui como um de seus pontos fortes a noção de "senso comum teórico" - é de fundamental importância atentar para duas obras que podem ser tidas como os alicerces desse projeto, quais sejam, Direito e sua Linguagem (1974) e Mitos e Teorias na Interpretação da Lei (1979), das quais vamos nos ocupar na sequência.

\subsection{2. - A semiologia do poder de Luis Alberto WARAT}

Em Direito e sua Linguagem, WARAT, apesar de declarar a sua opção pela semiologia, retorna a SAUSSURE para lembrar que, no bojo da problemática instaurada pelo fundador da Linguística, estava o fundamento de uma nova postura epistemológica, que permitiu revisitar as formas até então conhecidas de compreensão dos sistemas cínicos.

Segundo WARAT, o aspecto revolucionário do pensamento de SAUSSURE estava em considerar o primado do teórico sobre o real, ou seja, em proclamar que nenhum dado possui significação em si, independente das teorias ao seu respeito. Haveria, portanto, o plano do real concreto, daquilo que se poderia extrair empiricamente da realidade fática, meros dados sem significação, e o plano do real construído, formado pelo sentido que o sujeito atribui a esses dados. WARAT afirma que, para SAUSSURE,

[...] o objeto da ciência dos signos nunca pode ser um objeto dado, mas apenas produzido pelo próprio trabalho de investigação. A aplicação de uma teoria sobre os dados do real determina, segundo SAUSSURE, a sua configuração e o seu sentido. Deslocando ou redefinindo uma teoria, altera-se a significação dos dados. ${ }^{99}$

É evidente que surgem, a partir daí, novos subsídios para se pensar a epistemologia das ciências, e que esses novos fundamentos, tendentes ao rompimento da separação absoluta entre sujeito cognoscente e objeto cognoscível, encontram-se na esteira do paradigma da Filosofia da Linguagem.

WARAT remete, ainda, aos estudos do alemão RUDOLF CARNAP, a respeito da distinção entre linguagem-objeto e metalinguagem. Basicamente, o primeiro termo refere-

99 WARAT, Luis Alberto. O Direito e sua Linguagem. Buenos Aires: Cooperadora de Direito e Ciências Sociais, 1976, p. 19 
se à linguagem que se usa, enquanto o segundo alude à linguagem através da qual se fala da linguagem-objeto. Trata-se de níveis de linguagem distintos, necessários quando se elege, como objeto de estudo, a própria linguagem. Se esta passa a ser objeto, então é necessário criar um outro sistema de significação por meio do qual se torna possível falar desse objeto. Tal raciocínio é o mesmo que levou à criação da epistemologia, um saber que se constituiu enquanto ciência para possibilitar a compreensão e o aprimoramento dos fundamentos da própria ciência, de modo a garantir-lhe precisão. A epistemologia, portanto, é uma metalinguagem a partir da qual é possível falar sobre o saber científico, tornado objeto. É também uma espécie de "controle de qualidade", que autoriza seja um discurso proclamado como científico por respeitar os padrões e regras por ela definidos.

Segundo WARAT, os positivistas lógicos (ou adeptos do empirismo contemporâneo) logo perceberam que a importância do estudo da linguagem não estava, simplesmente, na possibilidade de otimizar as trocas simbólicas entre os indivíduos e, portanto, a transmissão de informações sobre as coisas do mundo. Eles cedo compreenderam que dominar a estrutura da linguagem constitui um poderoso instrumento de controle da transmissão do conhecimento. Integrar o grupo social que estabelece as características que diferenciam a linguagem adequada da defeituosa garantiria, assim, o "poder" de dizer que um dado discurso era digno de ser chamado de científico, porque havia observado os parâmetros que esse próprio grupo definira como condições necessárias de cientificidade.

Esse grupo dos positivistas lógicos, então, elegeu como uma das principais preocupações epistemológicas a questão da objetividade. Somente seria científico o conhecimento tido como objetivo, ou seja, o discurso mais próximo de corresponder às características do objeto analisado. Quanto menores as interferências sobre esse discurso, menores seriam as distorções no saber produzido. Para tanto, o sujeito cognoscente deveria livrar-se de todos os aspectos subjetivos que pudessem conduzir a uma visão deturpada do objeto, tais como qualquer forma de psicologismo e, principalmente, de ideologia. Somente o saber purificado da ideologia seria digno de ser intitulado como científico. A esse respeito, WARAT afirma:

Os neopositivistas aceitam, dessa forma, uma concepção da ciência que a desconecta de todos os compromissos políticos e de todos os efeitos ideológicos. Procuram um rigor sistemático, uma univocidade lógico-conceitual, que implica, na verdade, uma ilusão de despolitização, que não elimina os efeitos políticos dos discursos da ciência.

E prossegue:

Um discurso coerente e sistemático não deixa, por isso, de ser ideológico. A 
organização coerente de um discurso, por vezes, permite silenciar problemas; através de tais silêncios, os discursos cumprem funções políticas na sociedade, tornando-se, a partir dessa coerência, um discurso ideológico. Por outro lado, a coerência discursiva força, explicitamente, os sujeitos a dizerem ou reprimirem certas coisas. Por tais razões, pode-se afirmar que o discurso da ciência sempre terá uma dimensão ideológica ineliminável pela metalinguagem. ${ }^{100}$

Não foi possível evitar que essa visão epistemológica influenciasse o pensamento jurídico e os parâmetros de constituição da ciência do Direito, que nasce do interior do positivismo lógico. Esta corrente estabeleceu uma tipologia das linguagens classificandoas, basicamente, em linguagem natural e linguagem técnica. A primeira seria constituída pelo processo de enunciação na comunicação humana, considerado todo o seu caráter impreciso e o alto grau de dependência do enunciado em relação ao contexto comunicacional da fala cotidiana. Já a segunda seria a linguagem especializada, formada por enunciados dotados de rigor lógico e, portanto, desprovida de cargas emotivas e ideológicas. Nas palavras de WARAT, a preocupação dos positivistas lógicos, de construir uma linguagem técnica nesses moldes, revela "uma clara pretensão epistêmica, concretizada através de uma abstrata tentativa de expurgar, no plano da linguagem, os componentes políticos, as representações ideológicas e as incertezas comunicacionais da linguagem natural." ${ }^{101}$. E prossegue:

\footnotetext{
Através das linguagens técnicas, os filósofos vinculados às correntes que ora analisamos pretendem a construção de uma linguagem exclusivamente controlada por leis sintáticas, que operem como normas de precisão e univocidade. Seria, assim, uma linguagem produzida no interior de uma ciência pragmaticamente despreocupada. No entanto, sua construção logicamente controlada relacionaria elementos lingüísticos e os dados do mundo com precisão. Para caracterizações conceituais precisas, a linguagem ordinária é inadequada, devendo uma linguagem artificial ocupar o seu lugar a partir de um processo de elucidação da própria linguagem cotidiana. Dessa forma a ciência ficaria liberada de todos os componentes metafísicos. ${ }^{102}$
}

Esse processo de elucidação, a que WARAT se refere, é que permite a construção da linguagem técnica. Trata-se de um trabalho de esclarecimento da linguagem natural, ou seja, uma tentativa de elucidação do sentido das expressões cotidianas para que se tornem mais precisas e apresentem um sentido unívoco. A expressão linguística a ser elucidada ganha o nome de explicandum e, uma vez esclarecida, recebe o nome de explicatum, que, segundo WARAT, possui “designação e denotação unívocas, base referencial, satisfaz as

\footnotetext{
${ }^{100}$ Idem, ibidem, pp. 49-50.

${ }^{101}$ Idem, ibidem, p. 53.

${ }^{102}$ Idem, ibidem.
} 
condições de verdade e revela uma nítida ausência de elementos ideológicos" ${ }^{\text {"103. O }}$ resultado do processo de elucidação é, portanto, a linguagem técnica, que, assim como a linguagem ordinária, constrói-se a partir de dados colhidos da realidade, mas apresenta o rigor lógico-sistemático necessário para ser apresentada como linguagem oficial das ciências.

É importante frisar que esse processo de elucidação só é possível a partir de um processo de poder: aquele que detém o poder de dizer o que é essa linguagem técnica determina quando e como se produz conhecimento. Esse sujeito ou grupo conforma a realidade segundo o seu subjetivismo e interesses e, ao isolar dos demais a possibilidade de influenciar a produção desse conhecimento, torna-se possuidor de uma ferramenta de manipulação da realidade.

Entretanto, deve-se atentar para o fato de que o processo de elucidação revela importante característica inerente à própria constituição do saber jurídico. Se do ponto de vista dos positivistas lógicos, somente a elucidação da linguagem ordinária forneceria a linguagem adequada para a construção do discurso científico, então a ideologia remanesce como grande temática ausente, o que traz graves consequências, especialmente no âmbito das ciências sociais. Nesse sentido, segundo WARAT, "a ideologia parece ser um tecido maléfico que nos oculta a 'essência' do real. Em outras palavras, uma 'essência' analisada como equivalente a uma generalidade abstrata. Nesta perspectiva, produz-se a eliminação linguística da ideologia, assim como uma abstração e fuga da história.”. ${ }^{104}$

Na seara da filosofia ordinária da linguagem (mais especificamente da pragmática), a análise linguística centra-se, segundo WARAT, em duas preocupações específicas: as “incertezas significativas" e os "modos de significar". Ainda que não tenha optado por esse referencial filosófico, o autor reconhece que os ganhos obtidos através dessa linha de pensamento, de algum modo, enriqueceram as discussões tendentes a desconstruir "as falsas crenças dos juristas sobre suas linguagens" ${ }^{\text {105 }}$. No âmbito da discussão acerca dos modos de significar, ele ressalta a questão dos usos ou funções da linguagem, que surge a partir da constatação de que não é possível analisar o significado de um termo sem atentar para o contexto em que ele está inserido, ou seja, sem considerar a situação de fala, ou seja, o uso que é atribuído a esse termo no curso dos processos comunicacionais.

\footnotetext{
${ }^{103}$ Idem, ibidem, p. 60.

${ }^{104}$ Idem, ibidem, p. 62.

${ }^{105}$ Idem, ibidem, p. 64.
} 
Em geral, na filosofia da linguagem ordinária, são quatro os usos ou funções da linguagem: informativo, em que o emissor utiliza a linguagem para informar algo a respeito do mundo; emotivo, em que ele expressa cargas valorativas incidentes sobre um dado concreto; diretivo, em que se prescrevem condutas, de modo a obter do receptor um certo comportamento; e, finalmente, performativo, em que a fala é utilizada não para dizer coisas sobre o mundo, mas para realizar algum tipo de ação modificativa dele. WARAT sugere que essa classificação deveria ser enriquecida com uma quinta função da linguagem, que ele denomina "função de dominação", segundo a qual se teria em conta que, ao se manifestar através da linguagem, o homem traz consigo toda uma concepção de mundo, que permanece latente sob o discurso, de tal modo que a linguagem possui propósitos sociais até mesmo ocultos, como, por exemplo, a manutenção de certas relações de força.

WARAT lembra, então, que para ALF Ross, pensador vinculado à filosofia da linguagem ordinária (pragmática), a linguagem jurídica seria dotada, além das funções acima referidas, de uma outra, denominada fabulação (fabulation), através da qual seria possível uma manipulação da linguagem pelo emissor, que a utilizaria no sentido de fazer com que o receptor acreditasse em ficções. A esse respeito, esclarece WARAT:

\begin{abstract}
Os atos fabuladores, segundo Ross, são comuns na vida social para dissimular transgressões voluntárias ou involuntárias de tabus sociais. Os juristas, recorrendo aos atos fabuladores, 'fazem crer' na 'realidade substancial' de certas instituições e na 'racionalidade intrínseca' do direito. Como exemplo, podemos citar o princípio de que o juiz não modifica os sentidos da lei. (...). Através da condição fabuladora de sentido, pretende-se fazer acreditar que há uma proteção ao homem em abstrato, esquecendo-se suas condições reais de existência. Estamos, desta maneira, diante da lei como garantia formal, o que, por sua vez, não deixa de ser uma engenhosa fórmula de fabulação. ${ }^{106}$
\end{abstract}

Ao lado dos atos fabuladores, está uma outra classe de estratégia linguística, que garante um alto grau de persuasão discursiva. Trata-se do processo de estereotipação. WARAT explica, com apoio em BARTHES, que, através desse processo, associa-se à conotação de um termo uma carga emotiva elevada, que desloca a atenção do receptor para que este não perceba a vagueza significativa da expressão utilizada, diminuindo sua capacidade crítica quanto ao significado propalado.

No processo de estereotipação, é tão intensa a carga ética associada à conotação de uma palavra, que sua simples evocação pode conduzir a determinados comportamentos ou

${ }^{106}$ Idem, ibidem, pp. 68-69. 
opiniões sem que para tanto seja necessária qualquer associação a um nível de referência. Pode-se citar, como estereótipos, as palavras "justiça", "democracia" e até mesmo "direitos humanos". Tudo o que se diz, a favor ou contra essa ordem de ideias, provoca uma reação emocional no receptor, que, num primeiro momento, não consegue avaliar criticamente o discurso proclamado.

Verifica-se, assim, que os estereótipos possuem alto grau persuasivo e convencem aqueles que se identificam com a ideologia veiculada, e não com o significado de base do termo, que resta bastante enfraquecido. O processo de estereotipação se traduz, assim, num poderoso instrumento de alienação. Os estereótipos são, portanto, definições abstratas através das quais se propagam intensas cargas valorativas, ou seja, termos comprometidos ideologicamente. Nas palavras de WARAT:

\begin{abstract}
Em geral, podemos afirmar que os estereótipos constituem um elemento nuclear da transmissão de conteúdos ideológicos. São termos empregados para obter a consolidação e aceitação dos valores dominantes na sociedade. Assim, ao se dizer que alguém tem um direito subjetivo, se está reconhecendo a esta pessoa um privilégio social valorizado positivamente. Desta forma, mediante a utilização de uma linguagem impregnada de significações estereotipadas, consegue-se introduzir, sob a suposta aparência de uma descrição objetiva, uma dimensão ideológica não formulada na linguagem jurídica. O objetivo central de uma expressão estereotipada é o de influenciar e determinar opiniões. ${ }^{107}$
\end{abstract}

A criação desses estereótipos, que nada mais são que opiniões generalizadas e desprovidas de rigor científico, mas dotadas de elevado poder de persuasão, é que proporciona as condições discursivas necessárias à formação e consolidação do senso comum teórico.

É essa epistemologia tradicional, que apenas considera científico o discurso apolítico e que parte dos processos de elucidação, estereotipação e fabulação, anteriormente aludidos, para construir um saber pretensamente neutro, que WARAT pretende combater. E a arma que ele escolhe para auxiliá-lo nessa empreitada é a semiologia, campo do conhecimento que permite compreender a importância dos modos de significar, ou seja, que contém os fundamentos necessários à análise das razões pelas quais, no curso do processo de comunicação, as palavras mudam de significado.

WARAT considera a semiologia mais do que o aspecto epistemológico da linguística. Para ele, trata-se de um saber que se constitui enquanto contradiscurso ${ }^{108}$, ou

\footnotetext{
${ }^{107}$ Idem, ibidem, p. 71.

108 A noção de "contradiscurso" parece muito cara a WARAT. Entretanto, ele mesmo aponta um problema inerente à contradiscursividade, que pretende superar. Segundo o autor, todo contradiscurso, ao se propor
} 
seja, que é elaborado no interior de um discurso socialmente construído e que se propõe a denunciar o poder dos discursos. A semiologia contemporânea, contudo, na visão-desse autor, possuiria algumas limitações. Tal saber, apesar de constituir-se enquanto um contradiscurso, seria capaz de revelar relações de poder imiscuídas nos discursos socialmente reproduzidos, mas apenas do ponto de vista intersubjetivo, sem conseguir evidenciar o poder social dos discursos institucionais sobre a massa de indivíduos a ele sujeitos. Por tal razão, WARAT propõe a criação de uma "semiologia do poder" ou "semiologia política", que seria uma reflexão com pretensões de

[...] analisar a significação como instrumento de controle social, como estratégia normalizadora e disciplinar dos indivíduos, como fórmula produtora de consenso, como estágio ilusório dos valores de representação, como fetiche regulador de interação social, como poder persuasivo provocador de efeitos de verossimilhança sobre as condições materiais da vida, como fator legitimador do monopólio da coerção e como fator de unificação do contraditório exercício do poder social. ${ }^{109}$

Para o autor, todos os estudos que haviam se ocupado de uma análise linguística do Direito até então - lembre-se que tais afirmações foram feitas na década de 80 -, ou se restringiram a questões sintáticas e semânticas, ou situaram o saber jurídico como um fenômeno histórico, político e ideológico, mas sem adentrar na questão do poder dos (e nos) discursos. Ou seja, trata-se de estudos que ignoraram a necessidade de examinar a "pluridimensionalidade da relação poder-discurso" 110 no âmbito do Direito.

Partindo dessa constatação, e para dar cabo ao intento de construir um novo substrato teórico para a ciência do Direito, fundada na já mencionada epistemologia das significações, WARAT propõe o recurso a uma semiologia capaz de identificar as práticas políticas subjacentes à toda formação discursiva a respeito do Direito. E anuncia:

A semiologia que apoiará estes estudos deve começar por reconhecer a dimensão
ideológica e política das palavras, vendo-as como um lugar de poder. Deste
modo pretendo referir-me não só à possibilidade de considerar o discurso do
poder, mas também o poder do próprio discurso, tanto pelo estatuto tópico de
toda linguagem (sempre falamos em nome de um 'topos': da verdade, do bem

como crítica de um dado discurso, o faz a partir da estrutura desse mesmo discurso que critica. Assim, apesar de o contradiscurso possuir um forte potencial crítico, por mais paradoxal que possa parecer, verifica-se que a crítica produzida nesses termos não é forte o suficiente para romper com o discurso criticado, pois, no fundo, compartilha de suas bases. Num determinado momento de sua obra, ele parece preferir que sua proposta de uma semiologia do poder se assemelhe mais a uma metalinguagem, que "operando como um discurso crítico de uma determinada linguagem-objeto, revele simultaneamente as funções político-ideológicas e proponha critérios epistemológicos para a tematização de novas questões" (cf. Direito e sua Linguagem, p. 50). Contudo, isso não fica muito claro no pensamento do autor.

${ }^{109}$ Idem, ibidem, p. 18 .

${ }^{110}$ WARAT, Luis Alberto. À Procura de uma Semiologia do Poder. In Epistemologia e Ensino do Direito O sonho acabou, Florianópolis: Boiteux, 2004, p. 347. 
comum, da segurança, etc.) como pelas evocações repressivas que todos os discursos provocam. Esta Semiologia, proponho chamá-la Semiologia do Poder. $^{111}$

A proposta de um novo tipo de estudo semiológico sobre o Direito apenas terá êxito introduzindo-se a discussão da linguagem jurídica no interior da problemática aberta pelas diversas propostas de instituição do que poderíamos chamar uma teoria crítica da ciência jurídica. Uma teoria critica da ciência jurídica, tal como a concebo, não deve se preocupar com a constituição de uma normatividade para o conhecimento do Direito. Ela se define pela tentativa de elaboração de um contra-discurso apto a revelar o poder do conhecimento e seus condicionamentos sociais. ${ }^{112}$

Nesse sentido, o que o autor pretende é uma semiologia capaz de situar o discurso jurídico no interior das representações simbólicas da sociedade, nas quais o poder assume a função de condicionante de significações institucionalmente legitimadas, ou seja, que encontram respaldo estatal. Trata-se de uma semiologia jurídica que não está preocupada com problemas lexicográficos, mas em evidenciar a linguagem que se produz e se perpetua sob o manto do poder, como uma doxa travestida de episteme, no que se poderia encontrar as bases teóricas para uma nova configuração da ciência jurídica.

Percebe-se, assim, a íntima relação entre a semiologia do poder e a já referida proposta waratiana de construção de uma epistemologia das significações. Esta última evidencia a necessidade de um saber epistemológico crítico, que não se exima de explicitar os fatores condicionantes da gênese das ciências sociais. E a primeira, baseada nessa nova epistemologia, constitui-se no instrumento que permitirá detectar as ilusões de verdade que permeiam o discurso jurídico e que normalizam as relações sociais de maneira autoritária, ou seja, o meio que possibilitará vislumbrar as práticas ideológicas que, camufladas sob o Direito, fazem deste um forte componente de dominação social.

É importante destacar que WARAT situa a sua semiologia política no contexto do que ele denominou saber crítico do Direito $^{113}$, expressão cunhada por ele a fim de manifestar sua oposição e pretensão de desconstrução do chamado saber tradicional do Direito. Compreender essa distinção é fundamental para entender as bases epistemológicas que esse autor propõe para a ciência do Direito.

WARAT afirma que o pensamento crítico do Direito já produzido (lembre-se,

${ }^{111}$ Idem, ibidem, p. 347-348.

${ }^{112}$ Idem, O Direito e Sua Linguagem, p. 102.

${ }^{113}$ A esse respeito, conferir o texto Saber crítico e senso comum teórico dos juristas, publicado na Revista Seqüência, nº 05 , em 1982. 
novamente, que ele faz referência aos estudos realizados até a década de $80^{114}$ ), ainda não poderia ser apontado como um núcleo de enunciados sistematizados o suficiente para enfrentar a problemática das "condições históricas de elaboração e os vários sentidos sociais dos hábitos teóricos aceitos como o discurso competente dos juristas". Contudo, pondera que esse saber, entendido como "um conjunto de vozes dissidentes propõe um conglomerado de enunciados apto a produzir um conhecimento do direito, capaz de fornecer as bases para um questionamento social radical". ${ }^{115}$

Nesse sentido, o saber crítico traduz-se numa proposta epistemológica revisionista, a permitir um questionamento profundo das bases do saber tradicional a respeito do Direito. Segundo WARAT, esse saber é produzido ignorando-se os efeitos que as relações de força imiscuídas na sociedade exercem sobre o próprio objeto de estudo do Direito (e sobre aqueles que se sujeitam ao seu império, ou seja, os cidadãos). Tudo isso em nome do postulado da pureza metodológica, que, desde KELSEN, foi tido como o alicerce de todo conhecimento jurídico que se queira chamar de científico. Para WARAT, o pensamento crítico do Direito impõe a necessidade de se aceitar a primazia da política sobre a razão e a experiência jurídicas. Nas suas palavras:

\begin{abstract}
A ortodoxia epistemológica do direito não realiza a análise acima referida, visto que está preocupada, como o restante da epistemologia das Ciências Sociais, com o enclausuramento lógico referencial dos discursos produzidos em nome da ciência. Com isso, aliena o conhecimento cientifico em sua expressão material, como acontecimento significativo, politicamente determinado. Assim, a ortodoxia epistemológica reduz as significações a conceitos. Trata-se de uma démarche conceitual que procura colocar, fora de dúvidas e fora da política, a fala da Ciência. ${ }^{16}$
\end{abstract}

O autor segue explicando que, para a elaboração de um saber crítico do Direito, é necessário ter em vista a necessidade de se substituir o controle conceitual a respeito do fenômeno jurídico pela compreensão de seu sistema de significações, tarefa que não pode ser desempenhada sem que se introduza a temática do poder como algo enraizado em toda formulação pretensamente científica. Em termos epistemológicos, seria necessário, para o autor, romper com a concepção de que só é possível uma análise científica do Direito se a categoria do poder for excluída das preocupações do cientista. Ao contrário, ele chama a

\footnotetext{
${ }^{114}$ Frise-se que quando o autor fala de "pensamento crítico do Direito" não está se referindo à chamada "teoria critica", produzida pelos pensadores da Escola de Frankfurt.

115 WARAT, Luis Alberto. Epistemologia e Ensino do Direito - o sonho acabou, Florianópolis: Boiteux, 2004 p. 27.

${ }^{116}$ Idem, Saber Crítico e senso comum teórico dos juristas. In Revista Sequência, $\mathrm{n}^{\circ}$ 05. Florianópolis: UFSC, 1982, p. 21.
} 
atenção para o fato de que apenas uma postura diametralmente oposta, ou seja, que inclua a temática do poder como uma das principais preocupações do cientista do Direito, é que permitirá a análise adequada do fenômeno jurídico. Segundo ele

\begin{abstract}
A trajetória epistemológica tradicional concebe o mundo social como sendo um sistema de regularidades objetivas e independentes. Esta proposta sugere a coisificação das relações sociais, o que permite concebê-las em seu estado ingênuo. É precisamente a perda dessa ingenuidade que vai permitir a formação de uma história das verdades, que nos mostre o efeito político das significações da sociedade. ${ }^{117}$
\end{abstract}

É no bojo dessa discussão epistemológica que WARAT introduz o conceito de senso comum teórico, como veremos na sequência.

\title{
2.1.3. - Senso comum teórico dos juristas: noções precursoras, conceito e
} desdobramentos

A epistemologia tradicional, segundo WARAT, distinguiu duas formas de racionalidade: a científica e a do senso comum (ou cotidiana). A primeira estabeleceu, como questão fundamental, a definição dos parâmetros daquilo que deveria ou não ser considerado como ciência. A segunda, embora também reconhecida como uma forma de racionalidade, deveria ser excluída do saber pretensamente científico, porque formada de opiniões, concepções metafísicas e ideologia. Nesse sentido, a racionalidade científica avocou para si a tarefa de diferenciar a verdade do erro através da distinção entre episteme e doxa, como se isso fosse possível. Entretanto, revelado o caráter social e político dos processos de produção do conhecimento, percebe-se - como já foi dito - que apenas decisões políticas podem separar a doxa da episteme. WARAT conclui, assim que há nas ciências sociais uma "racionalidade mitológica que legitima politicamente uma doxa dissimulada como episteme" 118 .

Haveria, portanto, um "imaginário de referência a partir do qual se estabelecem as inibições, os silêncios e as censuras de todos os discursos das chamadas ciências humanas" ${ }^{119}$. Com isto, WARAT quer dizer que há um conglomerado de pré-compreensões, de instâncias significativas, de significações pré-discursivas, que permeiam e dão contorno ao discurso de verdade nas ciências, bem como regulam a forma de atuação dos produtores

\footnotetext{
${ }^{117}$ Idem, ibidem, p. 28.

${ }^{118}$ WARAT, Luis Alberto. Epistemologia e Ensino do Direito - o sonho acabou, Florianópolis: Boiteux, 2004 , p. 75.

${ }^{119}$ Idem, ibidem.
} 
e intérpretes desse discurso, impedindo o questionamento das raízes sociais das verdades produzidas.

Transportando essas constatações para o âmbito do Direito, o autor desenvolve a noção do "senso comum teórico dos juristas", que aparece, pela primeira vez, no prólogo do livro Mitos e Teorias na Interpretação da Lei. Na apresentação da obra, WARAT afirma que

[...] os ensaios propõem, em contextos diferentes, uma leitura sintomática das representações, noções e crenças que governam a tomada de posição concreta dos juristas em relação ao processo judiciário, e a sua produção teórica. Chamarse-á 'senso comum teórico' a essa montagem de noções - representações imagens - saberes, presentes nas diversas práticas jurídicas, lembrando que tal conjunto funciona como um arsenal de ideologias práticas ${ }^{120}$. Em outras palavras, essa montagem corresponde a normas que disciplinam ideologicamente o trabalho profissional dos juristas.

Ora, no trabalho jurídico, os diversos profissionais (juízes, advogados, professores, promotores, doutrinadores) são fortemente influenciados pelo 'senso comum teórico'. ${ }^{121}$

Segundo o autor, existem núcleos de conhecimentos sistematizados, que se intitulam teoria, bem como diversos discursos que se autoproclamam científicos, mas que trazem em seu bojo, ainda que de maneira velada, uma série de afirmações e justificativas ideológicas. Esses conjuntos de saberes que carregam em si um conglomerado de crenças, ainda que com ares de pretensa abstração, favorecem a reprodução despercebida de conteúdos ideológicos. Nas suas palavras:

\begin{abstract}
A ideologia em sua materialidade histórica determina um sistema de questões que comandam respostas favorecedoras de sua própria reprodução. É indubitável que a totalidade das respostas ideológicas constitui-se num corpo de conhecimentos. Precisando esta última afirmação, diríamos que o caráter abstrato da materialidade do ideológico aparece sob a forma de uma teoria ou, ainda, que o complexo de discursos mediante os quais se produz a abstração da ideologia constitui o que nomeamos 'senso comum teórico'. ${ }^{122}$
\end{abstract}

A partir dessa constatação, WARAT distingue as teorias científicas das ideológicas. Segundo ele, enquanto as primeiras se dedicam a compreender o real, as segundas

${ }^{120}$ Cf. ALTHUSSER, Louis. Filosofia e Filosofia Espontânea dos Cientistas. Lisboa: Editorial Presença, 1976. Esta referência a ALTHUSSER é feita pelo próprio WARAT, em seu texto, quando discorre pela primeira vez a respeito do "senso comum teórico". Consultando-se a obra mencionada, verificamos que ALTHUSSER designa, por ideologias práticas as "formações complexas de montagens de noções-representações-imagens nos comportamentos-condutas-atitudes-gestos. O conjunto funciona como normas práticas que governam a atitude e a tomada de posição concreta dos homens em relação a objectos reais e problemas reais da sua existência social e individual, e da sua história", p. 30.

${ }_{122}^{12}$ WARAT, Luis Alberto. Mitos e Teorias na Interpretação da Lei. Porto Alegre: Sintesis, 1979, p.19.

${ }^{122}$ Idem, ibidem. 
reconstroem esse real, reorganizando os dados da realidade segundo condicionantes ideológicos, de modo a assegurar a reprodução de práticas e concepções dominantes. Apesar de fazerem referência ao real, as teorias ideológicas são comandadas por certos interesses - em geral, daqueles que as elaboram ou que, de alguma forma, colaboram nessa tarefa -, de tal forma que as respostas buscadas já estão, de certo modo, pré-determinadas. Essas teorias seriam morais, porque se estruturam a partir de juízos éticos sobre os dados analisados, reproduzindo valores socialmente dominantes. Trata-se, portanto, de um saber profundamente marcado pelo senso comum teórico.

Por sua vez, as teorias científicas buscam a construção de um sistema de conceitos aptos a explicar a realidade examinada, mas com a pretensão de desmascarar os conteúdos ideológicos camuflados. Para WARAT, portanto, uma teoria será científica na medida em que, assumindo a existência de condicionantes ideológicos escondidos no saber acumulado, buscar compreender os dados da realidade em sua significação histórica. Um trabalho somente pode ser considerado científico, segundo esse autor, quando busca a transformação desse saber ideológico, que é o senso comum teórico, num saber que deixa claro o lugar ocupado pela ideologia no processo de produção de conhecimento. Uma teoria científica, portanto, não é aquela que simplesmente compreende a ideologia, mas aquela que amplia as dimensões do real ao revelar os fatores axiológicos que condicionam o saber produzido.

Assim, a primeira preocupação daquele que pretende fazer ciência deve ser a construção de um objeto de conhecimento segundo uma metodologia que permita enxergar com clareza em que medida os saberes já produzidos constituem-se num saber moral. É necessário que o cientista não tome o conhecimento produzido previamente à sua teoria como um "marco automático de referência"123, devendo problematizá-lo a fim de compreender em que sentido e com que propósitos ele foi produzido. É necessário que ele se indague: A que interesses esse saber acumulado atende? Em que momento histórico foi concebido? A que valores ele alude? Somente após responder a esse tipo de questões é que o cientista poderá tomar o saber já produzido para construir o seu objeto de estudo. Uma teoria que se pretende científica não pode ignorar a tarefa prévia de se libertar do senso comum teórico desse saber ideologizado que deve ser identificado antes de se tornar instrumento de análise.

${ }^{123}$ Idem, ibidem, p. 22 
WARAT chama atenção para o fato de que as teorias ideológicas somente são possíveis a partir de uma filosofia espontânea e especulativa - numa alusão ao conceito de "filosofia espontânea dos cientistas", formulado por LOUIS ALTHUSSER - que "se opõe à construção de um objeto científico, porque ela oculta os determinantes do real" "124.

ALTHUSSER trabalha o referido conceito no texto Filosofia e Filosofia Espontânea dos Cientistas, publicado em 1974, mas que se originou da introdução do "Curso de Filosofia para Cientistas", ministrado pelo autor, em 1967, na Escola Normal Superior, na França, juntamente a outros filósofos, e que durou até a véspera dos acontecimentos de maio de 1968.

Já no início do texto o autor responde à primeira pergunta que, muito provavelmente, aquele que se depara com o livro faz a si mesmo, qual seja, por que motivo um grupo de filósofos decidiu oferecer um curso de iniciação à filosofia para cientistas? "Por quê?", diz o autor, "Porque, à força de praticar nas obras da história da filosofia e das ciências, e de conviver com os nossos amigos cientistas, ficamos com uma certa idéia das relações que a filosofia tem necessariamente com as ciências”. E completa:

\footnotetext{
Melhor ainda: uma certa idéia das relações que a filosofia devia manter com as ciências para as servir em vez de as dominar. Melhor ainda: porque adquirimos, à custa de uma experiência exterior à filosofia e às ciências, mas indispensável à inteligência das suas relações, uma certa idéia da filosofia própria para servir as ciências. ${ }^{125}$
}

Assim, em termos gerais, verifica-se que a proposta do curso era mostrar que, embora se trate de saberes distintos, não é possível fazer ciência sem recorrer à filosofia. Primeiro, porque esta teria a função de identificar as "ideologias práticas" "126 que permeiam as ciências. Segundo, porque, na visão do autor, os cientistas reconhecem espontaneamente a existência da filosofia e sua posição privilegiada em relação à ciência. Tratar-se-ia de um reconhecimento inconsciente, mas que ficaria claro, por exemplo, nos períodos de "crise" que as ciências periodicamente atravessam e nos quais se notam três reações possíveis dos cientistas. A primeira seria a dos "sábios que mantêm a cabeça fria" e sequer se sentem abalados, os quais encaram a situação como uma simples provação, uma mera necessidade de rearranjar as teorias já construídas de modo a encontrar a saída da crise. A segunda, a dos "sábios que perdem a cabeça", os quais se veem tão abalados em suas convicções e tão assaltados pelo desespero, que colocam à prova não apenas uma determinada teoria, mas o

\footnotetext{
${ }^{124}$ Idem, ibidem.

${ }^{125}$ ALTHUSER, Louis. Op. Cit., p. 11.

${ }^{126}$ Sobre esse conceito, vide nota de rodapé 120.
} 
próprio valor das ciências. Entre esses dois extremos estaria uma terceira posição, qual seja, a dos "sábios que se põem a fazer filosofia". Estes vivem os momentos de crise como uma "questão filosófica" e se propõem a encarar as ciências a partir de uma perspectiva externa, a fim de problematizar os próprios fundamentos da prática científica. Nas palavras de Althusser, os cientistas que reagem dessa forma "reconhecem enfim que a 'crise' os tirou de seu 'dogmatismo': melhor, reconhecem tardiamente, uma vez acordados para a filosofia, que sempre, como cientistas, acalentaram em si um filósofo adormecido"127.

Segundo AlthUSSER existiria, portanto, uma "filosofia espontânea dos cientistas", que passaria silenciosa pelos períodos em que a ciência segue o seu curso normal, mas que, nos momentos de "crise", resplandeceria, vez que seria necessário criticá-la para, em seu lugar, colocar uma outra filosofia considerada "boa" pela comunidade científica. Essa filosofia espontânea dos cientistas não seria formada pela visão de mundo que eles possuem, mas pelas ideias que eles têm a respeito da própria prática científica. Além disso, seria formada por dois elementos: o primeiro, intracientífico, que diz respeito à existência do objeto de estudo, à eficácia do método científico e à objetividade dos resultados obtidos; e o segundo, extracientífico, "ligado às filosofias que exploram as ciências para fins apologéticos, em benefício de 'valores' de ideologias práticas não conhecidas e não criticadas". ${ }^{128}$ É importante frisar que, para ALTHUSSER, o segundo elemento teria primazia sobre o primeiro, de sorte que a prática filosófica dos cientistas somente teria valor crítico na medida em que eles empreendessem um esforço para reverter essa situação. Ou seja, para que o elemento intracientífico prevalecesse sobre o extracientífico, o que exigiria, em última instância, um esforço para libertar a ciência de toda e qualquer ideologia que a condiciona.

Além de Althusser, WARAT também aponta outros importantes antecedentes da noção de senso comum teórico. Refere-se à obra de ÉMILE DURKHEIM, que "já alertava sobre a presença de pré-noções, representações esquemáticas e sumárias que se formam pela prática e para ela" e que recebem "sua legitimação e autoridade pelas funções sociais que cumprem", e também do francês GASTON BACHELARD, que "denuncia por intermédio da idéia de obstáculo epistemológico as figuras do sentido comum que é necessário vigiar para romper com as falsas transparências que impedem a fecundidade do conhecimento". Por fim, o autor afirma que, para construir a noção de senso comum teórico dos juristas,

\footnotetext{
${ }^{127}$ ALTHUSER, Louis. Op. Cit., p. 90.

${ }^{128}$ Idem, ibidem, p. 135.
} 
também buscou subsídios em WITTGENSTEIN e NIETZSCHE:

O primeiro denunciando a linguagem comum que encerra em seu vocabulário toda uma filosofia espontânea do social, exorcizada verbalmente, em muitos casos, pela aparência de uma elaboração teórica precisa. As pré-noções podem contagiar os conceitos teóricos. O segundo expõe à critica a própria noção de verdade, mostrando a existência de uma dimensão ética que fundamenta uma vontade de verdade fora de todo controle epistemológico. ${ }^{129}$

A partir desses autores e pautado pela semiologia, WARAT constata que a função tradicionalmente conferida às ciências - nestas incluída a ciência do Direito -, qual seja, de descrever os dados da realidade como se estes possuíssem significações próprias, ignora por completo a historicidade desses dados, como se a eles não fosse atribuída uma significação concreta, uma dação externa de sentido que condiciona a forma com que são apreendidos. E, assim, ele chega a duas importantes conclusões, as quais parecem nortear esta fase de sua obra, em que ele estuda as relações entre Direito e Linguagem. A primeira é que as teorias jurídicas devem ser caracterizadas como senso comum teórico. E a segunda é que qualquer trabalho que se pretenda científico, a respeito do Direito, deve começar pela leitura sintomática desse senso comum teórico.

Assim, tal conceito continua sendo explorado e aparece em obras posteriores, como o texto Senso Comum Teórico: as vozes incógnitas das verdades jurídicas, escrito em 1983 e integrante do primeiro volume da sua Introdução Geral ao Direito ${ }^{130}$, livro que reúne diversos ensaios do autor elaborados entre o final dos anos 70 e o começo dos 80 . Nesse texto, WARAT afirma que o senso comum teórico designa as "condições de produção, circulação e consumo das verdades nas diferentes práticas de enunciação e escritura do Direito. Trata-se de um neologismo proposto para que se possa contar com um conceito operacional que sirva para mencionar a dimensão ideológica das verdades jurídicas"131 . E prossegue a respeito desse conceito:

\footnotetext{
Nas atividades cotidianas - teóricas, práticas e acadêmicas - os juristas encontram-se fortemente influenciados por uma constelação de representações (...), hábitos de censura enunciativa, metáforas, estereótipos e normas éticas que governam e disciplinam anonimamente seus atos de decisão e enunciação. Podese dizer que estamos diante de um protocolo de enunciação sem interstícios. Um máximo de convenções lingüísticas que encontramos já prontas em nós quando precisamos falar espontaneamente para retificar o mundo, compensar a ciência jurídica de sua carência. Visões, fetiches, lembranças, idéias dispersas, neutralizações que beiram as fronteiras das palavras antes que elas se tornem audíveis e visíveis, mas que regulam o discurso, mostram alguns dos componentes chaves para aproximarmo-nos da idéia do 'senso comum

${ }^{129}$ WARAT, Luis Alberto. Introdução Geral ao Direito vol. I - Interpretação da lei. Temas para uma reformulação. Porto Alegre: Sergio Antonio Fabris, 1994, p. 17.

${ }^{130}$ Idem, ibidem.

${ }^{131}$ Idem, ibidem, p.13.
} 
teórico' ${ }^{132}$

Segundo o autor, o esforço hermenêutico empreendido pelos juristas na tentativa de compreender e revelar o sentido do Direito, cria, aos poucos, uma espécie de cultura jurídica standardizada ${ }^{133}$. Um consolidado composto pelas diversas conclusões a que se chegou nessa empreitada, e que reúne um acumulado de valores, pré-conceitos e visões da realidade, que, em meio à prática burocratizada do Direito, ecoa sem que se reflita mais profundamente acerca de seu sentido. Para WARAT, esse saber jurídico consolidado - e muitas vezes replicado indistintamente - tem a função política implícita de reassegurar relações de poder insculpidas no seio social, de modo a garantir a manutenção do status quo vigente. Nas suas palavras:

\begin{abstract}
Aceitando-se que o Direito é uma técnica de controle social, não podemos deixar de reconhecer que seu poder só se pode manter estabelecendo-se certos hábitos de significação. Existe portanto um saber acumulado - difusamente presente nas redes dos sistemas institucionais - que é condição necessária para o exercício do controle jurídico da sociedade. (...). Produz-se uma linguagem eletrificada e invisível - o 'senso comum teórico dos juristas' - no interior da linguagem do direito positivo, que vaga indefinidamente servindo ao poder. ${ }^{134}$
\end{abstract}

WARAT ressalta que aceitar a noção de senso comum teórico exige uma espécie de "cumplicidade semiológica", no sentido de se concordar com a premissa segundo a qual tudo aquilo que os filósofos ou cientistas tradicionalmente chamaram de verdade não passa de uma complexa rede de significações tecida pelos diversos discursos construídos sobre o real. Nota-se, aqui, a clara influência da Filosofia da Linguagem no pensamento do autor, pois o conceito de senso comum teórico só pode ser compreendido através de uma perspectiva pragmática, ou seja, atenta ao contexto comunicacional em que são criadas as teorias científicas - que nada mais são do que uma série de enunciados logicamente ordenados de forma a constituir um discurso coerente e convincente sobre determinados objetos. Logo, antes de se concordar com a existência de um senso comum teórico nas

\footnotetext{
${ }^{132}$ Idem, ibidem, p.14.

${ }^{133}$ A esse respeito, LENIO LUIZ STRECK pontua: “(...) estabeleceu-se uma cultura jurídica standard, no interior da qual o operador do Direito vai trabalhar no seu quotidiano com soluções e conceitos lexicográficos, recheando, desse modo, suas petições, pareceres e sentenças com ementas jurisprudenciais, citadas, no mais das vezes, de forma descontextualizada, afora sua atemporalidade e ahistoricidade." E prossegue: "Há, na verdade, um conjunto de crenças e práticas que, mascaradas e ocultadas pela communis opinio doctorum, propiciam que os juristas conheçam de modo confortável e acrítico o significado das palavras, das categorias e das próprias atividades jurídicas - o que faz do exercício da profissão, como muito bem diz PIERRE BORDIEU, um mero habitus, ou seja, um modo rotinizado, banalizado e trivializado de compreender, julgar e agir com relação aos problemas jurídicos”. In Hermenêutica Jurídica (e)m crise, pp. 86-88.

${ }^{134}$ WARAT, Luis Alberto. Introdução Geral ao Direito vol. I - interpretação da lei temas para uma reformulação. Porto Alegre: Sergio Antonio Fabris, 1995, p. 15.
} 
ciências, é necessário aceitar a premissa segundo a qual os dados da realidade não possuem significação própria, senão os sentidos que lhes são conferidos pelos diversos enunciados construídos a seu respeito. Nas palavras do autor:

\begin{abstract}
Deste ponto de vista, a realidade é o nome geralmente empregado no pensamento ocidental para o traçado polifônico das versões interpretativas. O mundo não tem nenhuma distância de suas versões. Por este motivo, estaríamos forçados a admitir que as significações formam um texto que não se extrai da consciência ou da realidade, senão da própria circulação discursiva. Desta forma, precisamos admitir a existência de um princípio de intertextualidade pelo qual aprendemos que o sentido de um texto depende de sua própria história, e esta do diálogo surdo com os outros textos da cultura ${ }^{135}$.
\end{abstract}

Com efeito, WARAT desenvolve a categoria do senso comum teórico dos juristas para caracterizar o conjunto de representações idealizadas, imagens, metáforas, preconceitos valorativos e crenças axiológicas que formam o saber institucionalizado que confere legitimidade à ciência do Direito. Pode-se dizer que é através desse código, inscrito subliminarmente nos enunciados do discurso jurídico, que se consolidam "as funções sociais das leis, as dimensões políticas do direito e o seu papel determinante no projeto do Estado" "136. Ou seja, essas representações acerca do Direito, paulatinamente cristalizadas na prática cotidiana dos juristas e dos demais profissionais da área, fazem surgir os padrões sobre os quais a racionalidade jurídica se sustenta. E esta, uma vez consolidada, move-se por inércia, dando margem à criação de outras novas representações que a retroalimentam. É assim que, nesse círculo vicioso, tomam lugar os processos de produção de sentido caracterizados pela elucidação, estereotipação e fabulação, referidos anteriormente $^{137}$, os quais alimentam o senso comum teórico, reproduzindo-o, ao mesmo tempo em que são alimentados por ele. Exemplificativamente, pode-se dizer que, no senso comum teórico, "detecta-se a vigência da tradicional crença na forçosa neutralidade do conhecimento científico. Desta forma, se reproduz a antiga oposição entre ciência e ideologia, que indubitavelmente reforça os sonhos dos juristas em torno de uma ciência pura" ${ }^{\prime 38}$.

O mais novo fragmento que auxilia a compreensão do significado do senso comum teórico dos juristas encontra-se na obra recém-publicada A rua grita Dionísio!, em que WARAT aborda temas como Direitos Humanos, alteridade, linguagem jurídica, entre

\footnotetext{
135 Idem, ibidem.

${ }^{136}$ Warat, Luis Alberto. A Pureza do Poder. Florianópolis: UFSC, 1982, p. 55.

${ }^{137}$ Vide p. 63 e seguintes deste trabalho.

${ }^{138}$ Warat, Luis Alberto. Op. Cit, p. 56.
} 
outros. A respeito do senso comum teórico, ele afirma:

O SCT [senso comum teórico] chama de objetividade a um processo de construção que, longe de poder fotografar com fidelidade a realidade, a objetiva fazendo acreditar que a reflete como se um fosse um xerox do real. O que o SCT chama de objetivo é um modo de objetivação, produto da razão abstrata. A objetivação, confundida com a objetividade, é uma maneira de botar os chamados objetos do mundo (outra construção) numa perspectiva econômica, política, de dominação. (...). Assim, o SCT estabelece versões aceitas de um saber com pretensões de estabelecer desenhos naturais do mundo. O SCT (...) impõe massivamente idéias que nos fazem acreditar que o saber das ciências é uma espécie de copia fotográfica passiva de suas características externas e internas. Uma forma de deslocarmos diante da idéia de que o saber é uma construção histórica em devir, e assim é impossível de ser pensado como uma simples constatação de algo que é absolutamente alheio a nós, uma coisa préconstituída e independente dos observadores (que no fundo são produtores de saber). ${ }^{139}$

É interessante ressaltar que a noção de senso comum teórico dos juristas coadunase com conceitos desenvolvidos por outros filósofos do Direito, dentre os quais pode-se destacar TERCIO SAMPAIO FERRAZ JR., no momento em que este autor discute a questão da uniformização de sentido para a hermenêutica jurídica. Segundo ele, tal uniformização somente seria possível por meio do "poder de violência simbólica" - noção preconizada por PierRe Bourdieu e JEAN-Claude PASSERON: uma espécie de poder "capaz de impor significações como legítimas, dissimulando as relações de força que estão no fundamento da própria força" ${ }^{140}$, e que não se confundiria com coação, mas se caracterizaria pelo poder do emissor de controlar a ação do receptor - que conservaria suas possibilidades de ação, mas em conformidade ao sentido dado pelo emissor. Este, assim, neutraliza expectativas de comportamento do receptor, que continuam possíveis, mas não são levadas em consideração.

Destaca-se, também, que a identificação do senso comum teórico no discurso dos juristas não visa simplesmente a evidenciar a existência de posicionamentos ideológicos condensados na pratica jurídica, mas se pretende como fruto de um autêntico saber crítico sobre o Direito, porque permite desvelar os momentos em que o poder, subliminarmente, figura como condicionante extradiscursivo dos enunciados da ciência do Direito.

Aliás, como desdobramento da semiologia do poder e do esforço de detectar o senso comum teórico dos juristas, WARAT percebe que nenhuma teoria do Direito, nem mesmo a teoria kelseniana, deixou de ter caráter ideológico, porque todas sempre

\footnotetext{
${ }^{139}$ WARAT, Luis Alberto. A Rua Grita Dionísio! Lúmen Júris Editora: Rio de Janeiro, 2010, pp. 27-28

${ }^{140}$ FERRAZ Jr., Tercio Sampaio. Introdução a Estudo do Direito - técnica, decisão, dominação, $2^{\mathrm{a}}$ ed. São Paulo: Atlas, 1994, p.276.
} 
buscaram justificar a ordem jurídica ao invés de explicá-la. Em todas elas o senso comum teórico manifesta-se como uma filosofia espontânea que mascara o verdadeiro papel do Direito, somando-se a isso o fato de que a sistematização das normas positivadas, segundo esquemas lógicos complexos e bastante definidos, complementa a mensagem ideológica dessa filosofia especulativa que subjaz à atividade dos juristas. Esses dois aspectos, em conjunto, fornecem as bases para a consolidação do senso comum teórico, que se traduz num código dominante de significação jurídica, ou seja, um consolidado de crenças que constituem uma visão acerca do Direito, pretensamente neutra e científica, mas repleta de ideologia.

Essa é, aliás, a base da crítica waratiana à Teoria Pura do Direito. Preso às questões da objetividade e neutralidade científicas, KELSEN pretendeu construir uma ciência do Direito à margem de qualquer consideração de ordem axiológica. Esse teria sido, contudo, o grande equívoco do jurista austríaco: a negação das significações ideológicas que, necessariamente, perpassam o conhecimento jurídico. Segundo WARAT, qualquer teoria a respeito do Direito que se pretenda científica deveria se propor a compreender o saber jurídico acumulado a partir de seu ponto de vista histórico, ou seja, como um conhecimento produzido em determinadas condições de tempo e espaço, e que oculta seus determinantes a fim de reverberar a ideologia que lhe é subjacente. A tarefa de uma teoria sobre o Direito deveria ser, portanto, a de desmascarar o senso comum teórico que subjaz às enunciações do discurso da ciência jurídica.

WARAT também aponta outra inegável insuficiência da teoria kelseniana: fundada no já referido princípio da pureza metodológica, ela se nega a reconhecer que fatores extranormativos também funcionam como condição de significação das normas. Tratar-se-ia, contudo, de uma ilusão. Limitado o objeto da ciência do Direito à ordem jurídica e, portanto, a um discurso institucionalizado, aquele não pode deixar de ser considerado como um lugar de poder. Afinal, o direito posto resulta sempre de um ato político que provém de emissores que falam em nome do Estado e, portanto, a partir da ideologia do Estado. Além disso, a própria linguagem científica não figura como seara livre da influência do poder, como já se viu. Pode-se dizer que WARAT sintetiza, da seguinte forma, a sua critica à Teoria Pura do Direito:

Resumindo: a Epistemologia Crítica da Ciência nos ensina que a reivindicação de neutralidade ideológica e objetividade científica, utilizando um método que rejeita a infiltração da ideologia, não se apóia em sólidos argumentos 
epistemológicos, mas em justificações valorativas que, ao se apresentarem de forma encoberta, tornam-se plenamente eficazes. ${ }^{141}$

E o autor conclui, preciso:

\begin{abstract}
Assim, optar por uma ciência liberada da ideologia é optar por certa relação entre aquela e o mundo social. Trata-se de uma opção de valor, não pela ciência enquanto tal, mas pela função que a ciência possa cumprir com respeito às práticas sociais. É, portanto, uma opção ideológica feita no interior da epistemologia. No caso da Teoria Pura do Direito, a tentativa de escudar a Ciência Jurídica com uma suposta neutralidade ideológica e política encobre o empenho, talvez inconsciente, de ideologizar esse saber, preservando, assim, o seu poder. ${ }^{142}$
\end{abstract}

Torna-se inevitável concluir que a crítica de WARAT à teoria kelseniana só é possível a partir das premissas da semiologia do poder e do senso comum teórico dos juristas, especialmente porque o autor identifica como pertencente a este último a pretensão de um conhecimento científico neutro. Nas palavras do autor:

\begin{abstract}
Posso ainda afirmar, aprofundando um pouco mais as influências dos critérios epistemológicos, que no senso comum teórico dos juristas (visto como um complexo processo discursivo) detecta-se a vigência da tradicional crença na forçosa neutralidade do conhecimento científico. Desta forma, se reproduz a antiga oposição entre ciência e ideologia, que indubitavelmente reforça os sonhos dos juristas em torno de uma ciência pura ${ }^{143}$.
\end{abstract}

Outro importante desdobramento da análise crítica do Direito feita a partir da tematização da presença do poder dos discursos e nos discursos jurídicos, proporcionada pela semiologia política e pelo senso comum teórico dos juristas, e que merece destaque, aparece no campo das teorias da argumentação. Ao discutir esse assunto, WARAT insiste que o processo de convencimento não está atrelado ao alcance da verossimilhança, como usualmente se concebe, mas a um efeito de reconhecimento ideológico. Os métodos de interpretação do Direito teriam uma função retórico-política e não prático-científica ${ }^{144}$, conforme preconizado pela hermenêutica tradicional, profundamente influenciada pelo alemão FrIEDrich KARL Von SAVIGNY, no século XIX. A respeito desse autor, pondera TÉRCIO SAMPAIO FERRAZ JR.:

Após 1814 percebe-se na obra de SAVIGNY que a questão toma outro rumo e que o problema da constituição de um saber científico do direito enquanto saber hermenêutico se esboça. A questão deixa de ser a mera enumeração de técnicas, para referir-se ao fundamento de uma teoria da interpretação. Surge o problema de se explicar o critério (metódico) da interpretação verdadeira. A resposta

\footnotetext{
${ }^{141}$ WARAT, Luis Alberto. A Pureza do Poder. Florianópolis: UFSC, 1982, p. 51.

${ }^{142}$ Idem, ibidem.

${ }^{143}$ Idem, ibidem, p. 56.

${ }^{144}$ A esse respeito, cf. WARAT, Luis Alberto. Mitos e Teorias na Interpretação da Lei. Porto Alegre: Síntese, 1979.
} 
envolvia a determinação do fator responsável pelo sentido de unidade último e determinante do sistema. ${ }^{145}$

Nesse sentido, a concepção waratiana acerca da hermenêutica jurídica difere muito da tradicional. Para WARAT, não seria possível alcançar uma verdade hermenêutica, uma vez que a interpretação teria a função de construir a realidade jurídica.

Como é cediço, os profissionais do Direito estão sempre às voltas com a argumentação, empenhados em tentar convencer alguém a respeito de algo. A persuasão é, portanto, a principal ferramenta dos operadores do Direito. Mas não só. É também o mais importante instrumento à disposição dos juristas e daqueles que envidam esforços para elaborar teorias da dogmática jurídica. Toda vez que se discutem os significados das leis e dos institutos jurídicos, argumenta-se a respeito do sentido da norma e realizam-se práticas de redefinição das palavras da lei, mediante processos interpretativos variados. Portanto, não apenas os profissionais do Direito, tais como juízes, promotores, e advogados, desempenham suas funções, basicamente, argumentando, mas também aqueles que se pretendem "cientistas do Direito", e que realizam uma prática eminentemente argumentativa. Afinal, a aceitação das teorias científicas desenvolvidas depende do convencimento da comunidade acadêmica, que somente se efetiva através da argumentação.

Partindo dessa constatação, WARAT chama a atenção para a necessidade de se encarar criticamente a atividade de todos os que lidam com o Direito - tanto na prática, quanto na teoria. Somente assim seria possível compreender as razões pelas quais os argumentos se tornam convincentes, ou seja, os motivos pelos quais certos raciocínios empregados pelos operadores e cientistas do Direito se tornam mais ou menos persuasivos. Nas palavras do autor:

\footnotetext{
É preciso pensar profunda e criticamente esses temas e, afinal, iniciar uma investigação sobre os motivos pelos quais tais argumentos se afirmam convincentes, isto é, produzir uma investigação sobre a especificidade que possuem os argumentos para funcionarem como mediadores de uma mensagem significativa. ${ }^{146}$
}

Segundo WARAT, para que a atividade dos cientistas e operadores do Direito seja analisada dessa forma, é necessário trabalhar com teorias da comunicação e da ideologia,

\footnotetext{
${ }^{145}$ FERRAZ Jr., Tércio Sampaio. Introdução a Estudo do Direito - técnica, decisão, dominação, $2^{\mathrm{a}}$ ed. São Paulo: Atlas, 1994, p. 265.

${ }^{146}$ WARAT, Luis Alberto. Mitos e Teorias na Interpretação da Lei. Porto Alegre: Síntese, p. 113.
} 
pois somente assim é possível compreender as condições de produção de sentido dos enunciados da ciência do Direito. Daí é que decorre, como foi dito anteriormente, o seu interesse pela semiologia, área do saber que estuda a linguagem, no momento de sua enunciação (fala) e que, por isso, permite a compreensão da relação entre significante e significado. Entretanto, WARAT se propõe a elaborar uma semiologia do poder, porque entende que esta dimensão não é abarcada pela semiologia, tal qual constituída após os estudos de BARTHES. A esse respeito, pondera o autor:

\begin{abstract}
As práticas argumentativas do judiciário, da dogmática jurídica e das escolas de direito são manifestações concretas da ideologia dos juristas. A partir desse postulado ensaiaremos a elaboração de um texto critico sobre a teoria da argumentação e os argumentos. Consistirá ele, basicamente, numa leitura ideológica da argumentação jurídica, apoiada numa abordagem semiológica aberta, antiformalizante (...). Levando em conta que a Semiologia pode ser vista como uma teoria das formas, nossa investigação sobre a argumentação haverá de transcendê-la. Deve apoiar-se nela, mas se alterna com outros instrumentos interpretativos, principalmente como os estudos sobre a ideologia e o poder como formadores de um saber-poder. ${ }^{147}$
\end{abstract}

Partindo desses pressupostos e objetivos, WARAT destaca uma primeira noção que deveria integrar essa teoria crítica da argumentação. Trata-se da compreensão do processo argumentativo enquanto um ato de fala, um discurso que organiza uma série de signos argumentativos em função do poder. No curso da argumentação, portanto, os enunciados utilizados para persuadir o ouvinte seriam transformados em ideologia e esse movimento se constitui como condição fundamental para que ocorra o convencimento do receptor do discurso. Assim, a persuasão não depende de se alcançar a verossimilhança daquilo que foi dito, mas da identificação entre a ideologia propalada pelo emissor e as crenças e valores daquele que ouve o discurso. É por tais motivos que uma teoria crítica da argumentação, baseada numa semiologia que leva em conta o poder que atravessa os discursos, deve mostrar como os argumentos são manipulados a fim de garantir essa identidade de expectativas e ideologias que permitem obter o convencimento.

Para tornar mais claras as conclusões a que chega, WARAT relembra a distinção entre os raciocínios argumentativos e não-argumentativos no pensamento aristotélico. Os segundos, também conhecidos por raciocínios demonstrativos, ocorrem em situações nas quais os pontos de partida e as regras de derivação são claras. São raciocínios que almejam encontram a verdade, porque partem de premissas não contestadas e de regras silogísticas bem definidas que, permitem, regra geral, chegar a conclusões mais ou menos seguras a

${ }^{147}$ Idem, ibidem, p. 114. 
respeito da afirmação que constitui a base do raciocínio. A sua natureza demonstrativa advém do fato de que, explicitados os pontos de partida, as conclusões, de certa forma, já se encontram nas próprias premissas, razão pela qual o raciocínio é mera demonstração de como se chegou ao resultado. Já nos primeiros, também chamados de raciocínios retóricos, as premissas são formadas pelo conhecimento vulgar, pelas crenças populares, razão pela qual as conclusões a que se chegam são obtidas por meio de um processo valorativo e não demonstrativo. Assim, enquanto os raciocínios não-demonstrativos pretendem alcançar conclusões verdadeiras, os silogismos retóricos buscam convencer mediante um efeito de verossimilhança. Nas palavras de WARAT, o raciocínio argumentativo

[...] é uma dedução valorativa, uma espécie de ascensão cerimoniosa, na qual a conclusão é aceita porque se produz um efeito de adequação entre ela e o pensamento popular de base. Em conseqüência, o raciocínio argumentativo produz a persuasão de receptor e não a demonstração da conclusão. Defrontamos, assim, um raciocínio desconectado da verdade e vinculado à verossimilhança.

E acrescenta:

A verossimilhança predica sempre de enunciados cuja verdade se desconhece ou não se obteve legitimamente, mas que, de qualquer modo, aceita-se em função de certas crenças generalizadas ao nível popular e não científico. (...). $\mathrm{O}$ verossímil seria um tipo de afirmação que admitiria o contrário; sua verdade não submeteu-se à prova, mas postula o caráter de ser provavelmente verdadeira. ${ }^{148}$

Entretanto, WARAT questiona esse efeito de verossimilhança pretendido pelos raciocínios argumentativos, sustentando que o processo de convencimento está atrelado ao um reconhecimento ideológico entre emissor e receptor, que provoca esse efeito de realidade, que leva à persuasão. Assim, a partir da semiologia, WARAT desmistifica a busca pela verossimilhança que alicerça a teoria argumentativa tradicional - como se através da argumentação fosse possível alcançar uma espécie de "verdade mais fraca", que orientaria a tomada da decisão -, e sustenta que esse esforço nada mais é do que uma inferência ideológica que, ao provocar a imediata adesão do ouvinte ao discurso veiculado, produz um efeito de convencimento.

Além disso, WARAT chama a atenção para o fato de que a ciência, quando se dispõe a encontrar a verdade, também opera através da persuasão. Um cientista, ao elaborar uma teoria, tenta convencer a comunidade científica de que suas ideias são as que mais se aproximam da verdade a respeito de um determinado tema ou que suas reflexões é que

${ }^{148}$ Idem, ibidem, p. 117. 
oferecem a resposta correta a um dado problema. Para ter suas ideias aceitas, o cientista busca persuadir aqueles que o ouvem, de tal modo que as dificuldades acima apontadas, a respeito dos raciocínios não-demonstrativos (ou retóricos), tornam-se importantes para se pensar os limites e possibilidades do pensamento científico. Isso porque, se o cientista pretende alcançar a verdade e se ele está sujeito à necessidade de convencer a comunidade a respeito da veracidade de suas teorias, chega-se a um paradoxo, porque através do raciocínio argumentativo não se chega a conclusões verdadeiras, mas apenas verossímeis. A esse respeito, WARAT pondera que

A ciência persuade quando afirma operar com a verdade. Muitas formas de produção de conhecimento etiquetadas como científicas e apresentadas através de um conjunto de raciocínios demonstrativos, nada mais são que efeitos de realidade produzidos através do uso da verdade como lugar argumentativo. ${ }^{149}$

Partindo-se da constatação de WARAT de que a verossimilhança nada mais é do que um efeito de reconhecimento ideológico, percebe-se que os cientistas, por mais que almejem encontrar a verdade e se pretendam neutros nessa empreitada, somente conseguem convencer os demais a respeito de seu discurso valendo-se de raciocínios retóricos, que produzem um efeito de reconhecimento ideológico. E esse problema se torna ainda mais complexo quando se trata de pensar a ciência do Direito, em especial a dogmática jurídica, porque nestas é mais evidente o uso de raciocínios argumentativos.

Prosseguindo, WARAT sustenta que toda teoria da argumentação será ideológica se estiver fundamentada na noção de que o raciocínio argumentativo parte de opiniões comumente aceitas. Isso porque, como foi dito, não é disso que se trata, uma vez que o efeito de convencimento somente se alcança quando se parte das crenças dominantes, com o que o argumento se torna muito mais sedutor e, portanto, persuasivo. $\mathrm{O}$ interessante de se compreender o processo argumentativo nesses termos é perceber que, cada vez que um receptor aceita o argumento que chega até ele, não está simplesmente aderindo à ideologia que é veiculada e que torna a conclusão aceitável. Aceitando-se a argumentação, também se está reforçando o sistema de crenças que subjaz ao discurso a que se adere, retroalimentando-o. Convencer-se de algo não significa, apenas, concordar com a afirmação que resulta de um raciocínio retórico, mas um compartilhamento da visão de mundo entre emissor e receptor que, na medida em que se opera, reproduz e reassegura as crenças compartilhadas. Nesse sentido, para WARAT,

${ }^{149}$ Idem, ibidem, p. 118. 
[...] por meio da argumentação, realizam-se formas específicas de controle social. As afirmações que se pretende consolidar através de um argumento não só respondem, como também são textualmente determinadas. Elas cumprem, também, uma função socializadora latente, portam uma mensagem ideológica, são formas de reprodução dos valores estabelecidos previamente. ${ }^{150}$

Há, portanto, um conjunto de opiniões comumente aceitas, anteriores ao processo argumentativo, que, sendo compartilhadas entre emissor e receptor, garantem o efeito de reconhecimento ideológico que leva à persuasão. Esse conjunto de crenças, ao mesmo tempo em que é anterior ao raciocínio argumentativo, é por ele reproduzido, ao final, quando o convencimento se concretiza. Esse consolidado de valores que funciona, ao mesmo tempo, como condição para que a argumentação seja bem sucedida, e que é reproduzido ao final de todo esse processo, nada mais é do que o senso comum teórico.

Transportando essas considerações para o âmbito da atividade dos juízes, WARAT pondera que a argumentação por eles utilizada tem o papel não apenas de justificar a decisão tomada, mas também de reassegurar (reforçar) o sistema em que ela se baseia. Assim, por exemplo, quando um magistrado escolhe os argumentos que irão fundamentar sua decisão, "não está só tratando de persuadir sobre o tecnicismo de sua decisão, mas também se atendo à função socializadora que a sua sentença passará a cumprir". ${ }^{151}$

Parece importante destacar que tal conclusão não se restringe à atividade judicante, mas afeta as atividades de todos aqueles que lidam com o Direito. A figura do juiz, entretanto, talvez mereça maior ênfase, porque através da jurisprudência que o Direito se atualiza cotidianamente, e os precedentes criados influenciam a atividade de todos os demais operadores do Direito. Aliás, as novas significações que as normas recebem em razão das decisões judiciais influenciam, inclusive, as formulações da ciência do Direito, pois os juristas se veem obrigados a discutir os rumos tomados pela jurisprudência. É assim que, segundo WARAT, não apenas os juízes, mas, de modo geral, "os juristas contam com um mundo específico de crenças no qual se apóiam para raciocinar" e é "precisamente a partir desse mundo que se pode construir um conhecimento como o da dogmática jurídica" ${ }^{152}$. É interessante notar que, não fosse a análise do fenômeno jurídico a partir da semiologia, não seria possível a WARAT constatar essa ordem de circunstâncias que influenciam a argumentação jurídica.

\footnotetext{
${ }^{150}$ Idem, ibidem, p. 120.

${ }^{151}$ Idem, ibidem, p. 121.

${ }^{152}$ Idem, ibidem, p. 122.
} 
Apesar de fazer referência ao termo ideologia repetidas vezes, não se trata de um conceito claro na obra waratiana, muito menos um assunto que o autor tenha tratado de forma sistematizada. Há apenas pequenos lampejos, em certos textos esparsos, que fornecem pistas a respeito de como WARAT encara o conceito de ideologia. Um desses momentos, em que o autor enuncia, de certa forma, o que entende por ideologia, é um texto escrito em 1977, no qual ele afirma:

Por ideologia costuma-se entender o conjunto mais ou menos coerente de crenças que o grupo social invoca para justificar seus atos e respaldar suas opiniões, isto é, as crenças que funcionam como motivadoras ou racionalizadoras de determinados comportamentos sociais. Por tal razão a ideologia constitui-se de representações estritamente vinculadas ao exercício do poder social. ${ }^{153}$

Pode-se dizer assim que, para WARAT, ideologia seria a visão de mundo partilhada por determinado grupo de pessoas para pautar suas ações e, portanto, justificar seu posicionamento e suas atitudes perante o mundo. Esse autor não entende que a ideologia é algo que aliena, que mascara a realidade, mas que a modifica. Aliás, ele chega mesmo a afirmar que o tema é "muito mais complexo do que poderiam sugerir os esquemas elementares que tentam identificá-la [a ideologia] com um processo de alienação da consciência" ${ }^{154}$. Através do processo ideológico seria possível construir determinadas significações, a partir de crenças dominantes, atribuindo-se à realidade os mais diversos sentidos. Esse processo de ressignificação dos dados do real não seria despretensioso: ao contrário, teria caráter instrumental, pois dotado de finalidade específica, qual seja, criar cenários legitimadores das condutas sociais.

Após tecer essas considerações a respeito do que compreende por ideologia, WARAT aborda a sua influência no exercício de persuasão:

Para persuadir devemos dispor de um elemento duplicador das significações,
criar um efeito de homogeneização da mensagem. (...). Atrás de um argumento
que justifica uma decisão nova, ou, da redefinição que altera as decisões
socialmente aceitas, existe sempre um conjunto de padrões ideológicos que
tornam legitimável a decisão. O raciocínio retórico não faz outra coisa senão
acercar a decisão à ideologia de base. O argumento condiciona nossa disposição
de aceitar o poder decisório. ${ }^{155}$

WARAT também trata do tema da ideologia numa pequena passagem do texto "A Ciência Jurídica e seus dois maridos”, publicado em 1985. Ele afirma juntar as ideias de

\footnotetext{
${ }^{153}$ WARAT, Luis Alberto. Introdução Geral ao Direito. vol. I, Porto Alegre: SAFe 1994, p. 116

${ }^{154}$ Idem, A Pureza do Poder. Florianópolis: UFSC, 1982, p. 48.

${ }^{155}$ WARAT, Luis Alberto. Mitos e Teorias na Interpretação da Lei. Porto Alegre: Síntese, p.123.
} 
BARTHES e LEFORT para construir um conceito de ideologia que, ao menos até aquele instante, o satisfaz e que, como ele mesmo adverte, "trata-se de uma proposta de uso restrita à ordem simbólica na qual se inscrevem, necessariamente, as práticas discursivas das chamadas ciências sociais". Seria, assim, uma espécie de conceito epistemológico de ideologia, ou seja, atrelado ao seu funcionamento no âmbito dos discursos científicos.

O autor afirma seguir a trilha aberta por MARX, no sentido de compreender ideologia enquanto um mecanismo de dissimulação da contradição, ou seja, uma tentativa de anulação das influências da historicidade e espaço social como condicionantes da gênese dos discursos. O ideológico teria a função de simular uma sensação de unidade, camuflando os antagonismos, silenciando as dissonâncias do real e as diversas vozes sociais. Além disso, a ideologia constituiria um grave empecilho à consolidação de uma ordem verdadeiramente democrática, porque, ao pretender estabelecer sentidos unívocos ao complexo tecido de relações e significações sociais, assumiria o caráter de negação da pluralidade.

Nesse texto, WARAT chama a atenção para uma questão que considera de extrema importância quando se discute o tema da ideologia: trata-se do tratamento do ideológico como crença falsa ou falsa consciência. Segundo ele,

\footnotetext{
Esse posicionamento pressupõe entre outras coisas, a possibilidade de imacular alguns significados como unidade. Para isso se precisa contar com um conjunto de idéias e valores, com uma ordem simbólica que guie os comportamentos epistemológicos coletivos. Enfim, ao postular a ideologia como falsa consciência, omite-se a existência de uma consciência das verdades que se precisa aceitar, para pressupor a existência de uma consciência falsa.
}

Com isso, o autor quer dizer que apontar como ideológica uma dada assertiva, taxando-a de "falsa consciência" ou "falsa crença", implica, necessariamente, eleger como verdadeira uma outra compreensão de determinado ponto do real, o que constituiria, igualmente, um comportamento ideológico, do ponto de vista epistemológico - e até mesmo autoritário. Por tais motivos, WARAT prefere afastar-se da abordagem do ideológico enquanto consciência falsa e relaciona o tema à questão da falaciosa consciência de unidade que a ideologia ambiciona e provoca.

É interessante notar que não apenas o conceito de ideologia é impreciso na obra waratiana, como também a categoria do poder, que, apesar de mencionada diversas vezes pelo autor, não chega sequer a ser caracterizada. Warat utiliza o termo "poder" sem maiores rigores metodológicos. 
Um outro aspecto que possibilita uma melhor compreensão acerca da noção de ideologia na obra waratiana é o sentido que o autor confere ao termo "mito".

WARAT é categórico ao afirmar que o mito "é uma forma específica de manifestação do ideológico no discurso" ${ }^{\text {156 }}$. Trata-se, para ele, de um processo de construção de imagens e significações que, aparentemente referem-se à realidade tal como ela se apresenta, mas que escondem sentidos construídos ideologicamente e que são disseminados pelos diversos discursos dirigidos à sociedade e que pretendem a normalização das condutas sociais, como é o caso do Direito. Vê-se que o autor aborda o assunto não a partir da perspectiva antropológica, mas que se utiliza do termo para construir uma categoria do pensamento científico que permitiria reconhecer a presença de relações ideológicas no interior das ciências.

Para chegar a essa formulação, WARAT atém-se apenas ao conceito negativo de mito, que foi mencionado anteriormente ${ }^{157}$. Isso porque, apesar de reconhecer que o significado arcaico do termo diz respeito a um processo de compreensão do mundo, afirma, com apoio em BARTHES, que "tal processo consiste na substituição do tempo histórico-objetivo por uma sucessão de fábulas que apresentam as ações e acontecimentos como a concreção de protótipos eternos ritualmente alcançados", de forma que "o poder do mito, ou sua funcionalidade efetiva descansa no estar fora e acima do tempo"158.

É importante ressaltar que BARTHES compreende mito enquanto "mistificação", ou seja, como uma linguagem falaciosa, que impede o conhecimento do real e que, por isso, deve ser desmascarada. Para esse autor, o processo mitológico seria capaz de transformar a História em ideologia, pois impediria a compreensão do real através da construção de imagens idealizadas e da produção de significações baseadas em crenças. Como consequência desse processo, os homens aceitariam, sem questionar, qualquer forma de organização social que lhes fosse imposta como um "dado desde sempre", ou seja, como algo naturalizado e imutável, tal como eram os mitos.

Essa ideia de mito enquanto mistificação é trabalhada por BARTHES na obra Mitologias (1989), na qual o autor pretendeu evidenciar a camuflada presença dos mitos em três diferentes searas culturais: na imprensa, nas artes e nas propagandas comerciais veiculadas na França, na década de 50. Dentre os diversos exemplos utilizados por

\footnotetext{
${ }^{156}$ WARAT, Luis Alberto. Mitos e Teorias na Interpretação da Lei. Porto Alegre: Síntese, p. 127.

${ }^{157}$ Cf. página 38 e seguintes deste trabalho.

${ }^{158}$ WARAT, Luis Alberto. Mitos e Teorias na Interpretação da Lei. Porto Alegre: Síntese, p. 128.
} 
BARTHES nesse texto, o cientista político LUIS FELIPE Miguel destaca um que, ao seu ver, ilustra bem a percepção do semiólogo francês sobre do tema. Trata-se da análise da capa de um dos números da revista Paris-Match, que estampava um jovem soldado francês, negro, que com olhos fixos, saudava a bandeira tricolor. Essa imagem evocaria uma ilusória sensação de harmonia na sociedade francesa da época, porque, implicitamente, trazia a mensagem de que até mesmo um jovem negro, a despeito do imperialismo francês, estava a servir os seus opressores. O mito estaria presente nessa representação porque ela "não esconde a presença do colonialismo francês, mas a deforma, fazendo passar por conformidade e parceria o que é tensão e opressão" ${ }^{\text {159 }}$. Sobre o assunto, BARTHES afirma:

O mito é uma fala despolitizada. Naturalmente, é necessário compreender política em sentido profundo, como conjunto de relações humanas em seu poder de construção do mundo; sobretudo, é necessário dar um valor ativo ao sufixo des: aqui representa um movimento operatório, um fazer desaparecer, um abandono. No caso do soldado negro, por exemplo, o que se elimina, certamente, não é o imperialismo francês (muito pelo contrário, é o que se quer fazer presente), senão a sua qualidade contingente, histórica, ou seja, construída, do colonialismo. O mito não nega as coisas, sua função, ao contrário, é falar delas; simplesmente as purifica, as torna inocentes, lhes confere a aparência de natureza e eternidade, dá-lhes uma clareza que não é de explicação, mas de comprovação: se comprovo o imperialismo francês sem explicá-lo, estou a um passo de achá-lo natural, algo que cai por seu peso; fico tranquilo. Ao transformar a história em natureza, o mito faz uma economia: consegue abolir a complexidade dos atos humanos, dá-lhes a simplicidade das essências, suprime a dialética e qualquer superação que vá mais além do visível imediato, organiza um mundo sem contradições, porque não tem profundidade, um mundo apegado à evidência, fundado uma claridade feliz: as coisas parecem significar por si mesmas. (traduzimos livremente). ${ }^{160}$

É assim que WARAT, pautado no conceito de mito desenvolvido por BARTHES, explica que o processo mitológico é movido por pretensões de universalização dos

\footnotetext{
${ }^{159}$ MIGUEL, Luis Felipe. Em Torno do Conceito de Mito Político. Dados, Rio de Janeiro, v. 41, n. 3, 1998 Disponível em http://www.scielo.br/scielo.php?script=sci_arttext\&pid=S001152581998000300005\&lng=en\&nrm=iso Último acesso em 25.12.2009

${ }^{160}$ No original lê-se: "el mito es un habla despolitizada. Naturalmente, es necesario entender política en el sentido profundo, como conjunto de relaciones humanas en su poder de construcción del mundo; sobre todo es necesario dar un valor activo al sufijo des: aquí representa un movimiento operatorio, actualiza sin cesar una defección. En el caso del soldado negro, por ejemplo, lo que se elimina, ciertamente, no es la imperialidad francesa (muy por el contrario, es lo que se quiere hacer presente), sino la cualidad contingente, histórica, en una palabra, construida, del colonialismo. El mito no niega las cosas, su función, por el contrario, es hablar de ellas; simplemente las purifica, las vuelve inocentes, las funda como naturaleza y eternidad, les confiere una claridad que no es la de la explicación, sino de la comprobación: si compruebo la imperialidad francesa sin explicarla, estoy a un paso de encontrarla natural, que cae por su peso; me quedo tranquilo. Al pasar de la historia a la naturaleza, el mito efectúa una economía: consigue abolir la complejidad de los actos humanos, les otorga la simplicidad de las esencias, suprime la dialéctica, cualquier superación que vaya más allá de lo visible inmediato, organiza un mundo sin contradicciones puesto que no tiene profundidad, un mundo desplegado en la evidencia, funda una claridad feliz: las cosas parecen significar por sí mismas". In BARTHES, Roland. Mitologias, 12 ed. Madrid: Siglo xxi editores, 1999, p. 129.
} 
conteúdos mitificados. Silenciando-se as vozes dissonantes, torna-se possível construir imagens e significações baseadas em determinadas crenças, o que imprime uma aparência de unidade e harmonia às práticas sociais. A conformação da realidade que se obtém a partir desse silenciamento é aceita sem maiores indagações, o que garante, através do êxito do processo mitológico, a disseminação de conteúdos ideológicos - em geral, aqueles que interessam aos grupos que monopolizam a enunciação dos discursos sociais. Haveria, portanto, uma estrita relação entre "mito" e "ideologia", que WARAT expressa nesta passagem:

\begin{abstract}
Mito, fetiche, ideologia, como expressões sinônimas, remetem-nos a um corpo racional de mecanismos significativos, que se dirigem à legitimação e organização de certas relações sociais, silenciadas no discurso. A construção de um fetiche implica na cristalização de certos fenômenos ou processos sob a forma de um discurso posto a parte, abstraído das condições que presidiram sua produção. Mediante a produção de conceitos, fetiches ou mitos, obtém-se um efeito de racionalidade substancial para as descrições das relações econômicas, políticas e jurídicas. Desta forma, como consequiência do emprego de conceitos fetichizados, consegue apresentar os elementos, fatores ou funções das relações sociais como objetos que possuem uma existência autônoma e superior à do sujeito social. Nessa perspectiva, a cultura jurídica pode ser vista como um discurso fetichizado. ${ }^{161}$
\end{abstract}

Segundo WARAT, no âmbito do Direito, esse processo torna-se mais visível quando se analisa o fascínio que o "espírito do legislador" sempre provocou na hermenêutica tradicional. Trata-se do maior e mais evidente esforço de homogeneização de sentidos e representações jurídicas, uma tentativa de mitigação das contradições sociais subjacentes aos conflitos tratados pelo Direito, ou seja, um esforço para formular esquemas ideais tendentes não à resolução das disputas, mas à sua sufocação.

E o autor prossegue, sustentando que a força do processo mitológico está no fato de que ele "não tem por função deformar a realidade, mas sim fornecer dados da dinâmica social num plano de abstração conceitual cristalizada. Neste plano, sob o pretexto de racionalização sobre os dados, confirmam-se os valores". ${ }^{162}$ Torna-se evidente, assim, a ligação que entre os conceitos mito e senso comum teórico na teoria waratiana. A mitificação é responsável pela consolidação de crenças, representações e significações que, na ciência e na prática do Direito, constituem o senso comum teórico dos juristas.

WARAT é apontado, por vezes, como um "eterno caçador de mitos" 163 e realmente é essa a impressão que temos quando nos deparamos com sua obra. Pautado no conceito de

\footnotetext{
${ }^{161}$ WARAT, Luis Alberto. A Pureza do Poder. Florianópolis: UFSC, 1982, p. 55.

162 WARAT, Luis Alberto. Mitos e Teorias na Interpretação da Lei. Porto Alegre: Síntese, p. 137.

${ }^{163}$ Cf. o prefácio do livro de Warat intitulado A Rua Grita Dionísio!, escrito por Alexandre da Rosa.
} 
ROLAND BARTHES, para quem o processo mitológico corresponderia a uma situação de mistificação - como foi acima explicitado -, WARAT saiu à procura dos diversos mitos que subjazem ao discurso da ciência jurídica e se dispôs a revelá-los. E parece ser possível sustentar que a maior ilusão que o autor tentou identificar e desconstruir foi, por assim dizer, o mito fundante de todos os demais mitos jurídicos, qual seja, o de que a ideologia não pode ser considerada como preocupação da epistemologia da ciência do Direito, sob pena de se comprometer a sua objetividade. Não foi por outro motivo que ele desenvolveu o conceito de senso comum teórico dos juristas: trata-se da forma encontrada pelo autor para evidenciar o conjunto de imagens e representações que permeiam a ciência do Direito, e que se pretendem como dotadas de cientificidade, mas que, no fundo, não passam de uma doxa travestida de episteme, como se disse.

Considerados esses aspectos, fica a seguinte pergunta: seria a neutralidade na prestação jurisdicional parte desse senso comum teórico que atravessa despercebidamente a ciência e a prática do Direito? Essa questão será enfrentada no tópico seguinte e já aponta para o desfecho deste trabalho.

\subsection{Senso comum teórico dos juristas, ciência do Direito e magistratura: é possível cogitar de neutralidade na prestação jurisdicional?}

Conforme vimos ao longo deste trabalho, o senso comum teórico dos juristas é constituído pelo imaginário que permeia a ciência do Direito, uma espécie de corpus de representações, imagens, crenças, ficções e "pseudocertezas" que subjazem à prática cotidiana do Direito e que assumem a forma de enunciados objetivos, científicos, mas que, na realidade, nada são além de uma doxa disfarçada de episteme. Trata-se, portanto, de uma série de afirmações que, embora se pretendam verdadeiras a respeito de diversos aspectos do fenômeno jurídico, em especial sobre o sentido das normas, não passam de meras opiniões consolidadas, senso comum cristalizado. Um discurso que se autoproclama rigoroso, porque fruto de observações supostamente científicas, mas que se revela frágil quando sujeito a um exame mais acurado que parta da tematização do poder veiculado subliminarmente às falas institucionalizadas tais como o Direito.

Com efeito, ao apontar a existência de um senso comum teórico na prática dos juristas, WARAT realiza uma profunda crítica à hermenêutica tradicional, cujo objetivo era encontrar o correto sentido das normas e seu real alcance, como se estas fossem dotadas 
de uma significação unívoca nelas presente desde o momento de sua positivação e que pudesse ser desvendada através da aplicação de rigorosas técnicas interpretativas. A existência de um senso comum teórico na prática dos juristas, ou seja, de concepções ilusórias, sedimentadas, que dão os contornos da racionalidade jurídica, mostra que diversos conceitos veiculados como verdades hermenêuticas não passam de convenções que atendem a determinados interesses. Com sua crítica, WARAT chama atenção para a necessidade de se investigar os reais motivos que engendraram o nascimento de certos enunciados da ciência jurídica, seja aqueles que tangem à estrutura a ela conferida, seja os que concernem ao significado atribuído às normas na prática interpretativa.

LÊNIO STRECK, partindo da obra de WARAT, dedicou-se a identificar diversas crenças e concepções solidificadas no universo do Direito que poderiam ser classificadas como parte do senso comum teórico dos juristas. Ele aponta, por exemplo, que uma observação mais atenta do Código Penal mostra que esse diploma, muitas vezes, pune com mais rigor os crimes contra o patrimônio do que os contra a vida. Isso revelaria a presença, no Direito Penal, de uma ideologia liberal-individualista, que confere valor excessivo ao direito de propriedade em detrimento de outros como a vida. Para ilustrar tal afirmação, esse autor faz a seguinte comparação: "adulterar número de chassis é crime punido com 3 a 6 anos de reclusão e multa, pena mínima superior a de, por exemplo: a) lesão corporal grave em que a vítima perde, por exemplo, um dos olhos. Neste caso a punição é de 1 a 5 anos"164. Esses paradoxos e contradições da dogmática jurídica passam despercebidos pelos profissionais do Direito, que, na sua prática cotidiana, não se questionam acerca dos condicionantes histórico-sociais da realidade com que lidam.

Outro interessante exemplo que esse autor traz diz respeito à polêmica envolvendo a edição da Lei $n^{\circ}$ 9.639/98, em cujo projeto havia dispositivo que concedia anistia a agentes políticos que tivessem sido responsabilizados por determinados crimes previdenciários (art. 11). O projeto foi aprovado pelas casas legislativas e encaminhado à sanção presidencial. Ocorre que, misteriosamente, foi acrescido um parágrafo "fantasma" ao aludido art. 11, que culminou por estender a referida anistia de maneira irrestrita. Constatado o equívoco, a lei foi republicada no dia seguinte ao de sua publicação original. Segundo STRECK, as conseqüências advindas do acréscimo indevido de um preceito "pirata" parecem, à primeira vista, de fácil resolução: se o dispositivo não passou por

${ }^{164}$ STRECK, Lenio Luiz. Hermenêutica Jurídica e(m) crise. $4^{\text {a }}$ ed. Porto Alegre: Livraria do Advogado, 1999, p. 73. 
votação no parlamento, jamais ingressou na ordem jurídica e, portanto, nunca produziu efeitos.

Entretanto, com perplexidade, o autor explica que

[...] com base na 'vigência' do aludido parágrafo único do art. 11, começaram a ser concedidas anistias a todas as pessoas envolvidas nos crimes de retenção de contribuições sociais, sob os mais variados argumentos, tais como 'em nome da segurança jurídica, o texto publicado, apesar de erro, existe e entra em vigor, devendo ser protegidos os direitos decorrentes dessa vigência...', etc., aduzindose, ainda, citações doutrinárias acerca da interpretação do art. $1^{\circ}, \S^{\circ}$, da Lei de Introdução ao Código Civil...

Em face disso, o Ministério Público Federal passou a recorrer das (centenas de) decisões judiciais concessivas das anistias irrestritas baseadas no inexistente Parágrafo único, tendo que a matéria ser, finalmente, decidida pelo Supremo Tribunal Federal, que, em decisão plenária de 4.11 .98 (HC n. 77724-3, rel. Min. Marco Aurélio), julgou inconstitucional o citado parágrafo único do art. 11 da Lei 9.639, em sua publicação no Diário Oficial da União de 26.5.98, explicitando o STF que a decisão tinha caráter ex tunc, atingindo todas as decisões concessivas anteriores. A argumentação do Supremo Tribunal Federal foi singela - porque singela era a questão, sem dúvida -, baseando o acórdão no fato de que o Parágrafo único em tela não cumpriu, no Congresso Nacional, o rito de discussão e votação de projeto de lei, previsto no art. 65 da CF. Ou seja, a publicação por engano do Parágrafo único não poderia gerar efeitos no mundo jurídico. ${ }^{165}$

O exemplo acima ilustra a esquizofrenia com a qual se realiza a hermenêutica jurídica quando os profissionais do Direito, cegos pelo senso comum teórico, não conseguem enxergar o texto da norma além de sua literalidade. Presos a uma cultura jurídica estandardizada, ao formalismo, ao rigor metodológico que exige a conformação das nuances das situações concretas a um silogismo exato, esses profissionais estão mais preocupados em encontrar a técnica interpretativa adequada para garantir a coerência e a coesão do raciocínio hermenêutico do que em pensar a respeito da questão que lhes é apresentada. Agindo de forma rotinizada, como autômatos, não conseguem notar as obviedades dos problemas jurídicos e muito menos os momentos em que o discurso da ciência do Direito não é outra coisa senão um discurso de poder. E em face dessa dificuldade de visualizar o senso comum teórico em que estão mergulhados, conscientemente ou não, colaboram para a reprodução dos valores por ele petrificados e para a manutenção dos status quo.

Outra prática que pode ser considerada como integrante do senso comum teórico dos juristas é a referência - em petições, pareceres e até mesmo em decisões judiciais - a

${ }^{165}$ Idem, ibidem, p. 78. 
precedentes jurisprudenciais sem as devidas cautelas ${ }^{166}$. Expressões comumente utilizadas tais como "segundo a jurisprudência majoritária" ou "a jurisprudência é mansa e pacífica" deveriam sempre provocar um sentimento de desconfiança. Em geral, tais afirmações não são acompanhadas de pesquisa sólida o bastante para certificar a correção da remissão feita. Além disso, não é incomum que ementas ou trechos de acórdãos sejam citados de forma descontextualizada, sem referência à situação concreta que os engendrou, de sorte que uma averiguação um pouco mais detida revela, muitas vezes, que o precedente citado sequer dizia respeito à hipótese fática para a qual havia sido invocado.

O senso comum teórico também invade as salas de aula e macula a formação dos profissionais do Direito. O ensino jurídico é compartimentado, atrelado à clássica dicotomia entre direito público e privado e não prioriza a compreensão dos diversos ramos do Direito como um todo unitário regido pela Constituição, o que dificulta sobremaneira o enfrentamento dos conflitos sociais contemporâneos, que em grande parte possuem natureza transindividual. Trata-se de um ensino preocupado apenas em dotar os futuros profissionais de habilidade para lidar com o instrumental técnico necessário ao manejo de recursos, petições e pareceres, e não para refletir acerca dos problemas sociais concretos e, a partir deles, compreender e questionar as estruturas jurídicas solidificadas. Ademais, o ensino que se tem nas faculdades de Direito não raras vezes é desconectado da realidade, o que favorece a consolidação e a reprodução do senso comum teórico. Como afirma STRECK

Ocorre, assim, uma ficcionalização do mundo jurídico, como se a realidade
social pudesse ser procustianamente aprisionada/moldada/explicada através de
verbetes e exemplos com pretensões universalizantes. Alguns exemplos beiram o
folclórico, como no caso da explicação do 'estado de necessidade' constante do
art. 24 do Código Penal, não sendo incomum encontrar professores (ainda hoje)
usando o exemplo do naufrágio em alto-mar, em que duas pessoas (Caio e Ticio,
personagens comuns na cultura dos manuais) 'sobem em uma tábua', e na
disputa por ela, um deles é morto (em estado de necessidade, uma vez que a
tábua suportava apenas o peso de um deles...!) Cabe, pois, a pergunta: por que o
professor (ou o manual), para explicar a excludente do estado de necessidade,
não usa um exemplo do tipo "um menino pobre entra no Supermercado
Carrefour e subtrai um pacote de bolacha a mando de sua mãe, que não tem o
que comer em casa?". Mas isto seria exigir demais da dogmática tradicional.
Afinal de contas, exemplos desse tipo aproximariam perigosamente a ciência
jurídica da realidade social...!'l67

Considerando-se tudo o que foi dito, parece-nos possível sustentar que a própria

\footnotetext{
${ }^{166}$ A esse respeito, cf. STRECK, Lenio Luiz. Op. Cit, p. 86 e seguintes.

${ }^{167}$ STRECK, Lenio Luiz. Hermenêutica Jurídica e(m) crise. $4^{\mathrm{a}}$ ed. Porto Alegre: Livraria do Advogado, 1999, p. 85 .
} 
exigência de neutralidade na prestação jurisdicional compõe o senso comum teórico dos juristas. Como vimos, para não se comprometer o esquema racionalista que garantia o bom funcionamento do Estado moderno liberal, concebeu-se a figura do juiz neutro, que, como simples engrenagem do maquinário estatal, estava obrigado a executar o seu mister de forma a não comprometer o pulsar desse organismo. Entendia-se, naquela época, que os julgamentos somente seriam justos se fossem fiéis às leis, que eram consideradas como intrinsecamente justas, porque expressavam a vontade popular. Assim, pautado nas normas de Direito positivo, o juiz não decidiria segundo sua vontade pessoal, mas conforme a do povo. Portanto, era a aplicação da letra fria da lei que garantiria a Justiça, pois qualquer leitura que o juiz fizesse das normas, a faria segundo suas próprias convicções, em detrimento das expectativas da comunidade consagradas no sistema jurídico. Ao magistrado, portanto, não era dado sopesar as consequências de seus julgamentos, porquanto a avaliação da justiça da norma já havia sido feita no curso do processo legislativo.

Percebe-se, assim, que dogma da neutralidade na prestação jurisdicional foi criado como tentativa de minimizar a influência do subjetivismo nas decisões judiciais.

A figura do juiz neutro foi reforçada pelo racionalismo positivista que caracterizou a ciência jurídica na modernidade. Como vimos, a Teoria Pura do Direito foi concebida no interior desse ideal positivista, que equiparava cientificidade e objetividade, e traduziu-se num esforço para livrar a ciência jurídica de todo e qualquer resquício de subjetivismo. Entretanto, a amputação da ideologia e da sensibilidade do domínio da ciência jurídica constitui o grande erro da teoria moderna do Direito, que, agora, nos vemos obrigados a reparar.

Isso porque, caso o sistema democrático funcionasse como se pretendia - ou seja, se as leis realmente representassem a vontade do povo e não fossem o fruto de meticulosas articulações políticas que, muitas vezes, fazem com que certos interesses privados prevaleçam -, então nada haveria de errado com o juiz que se limitasse a aplicar a letra fria da lei. Todavia, se o magistrado age como autômato diante de normas que representam os interesses de alguns poucos, então essa neutralidade gera injustiça e desigualdade, e não justiça e igualdade como se pretendia.

Ocorre que, apesar desse descompasso entre as expectativas em torno do sistema democrático e sua real configuração, a exigência de neutralidade no exercício da judicatura 
continua a ser defendida por muitos - conscientemente ou não. Exemplo disso é a resistência encontrada na doutrina e na prática do Direito quanto à possibilidade de o Judiciário analisar o mérito do ato administrativo ${ }^{168}$, sob o argumento de que essa conduta fere o princípio da tripartição e independência dos poderes. Trata-se de uma concepção tão sedimentada no Direito administrativo brasileiro que o assunto deixa de ser analisado sob a óptica da existência de preceitos constitucionais de ordem material que também devem nortear a atuação do Poder Público. É dizer: esquece-se de que há promessas constitucionais cujo cumprimento deve ser exigido, sob a tosca justificativa da necessidade de observância ao princípio da tripartição dos poderes, como se este se apresentasse nos mesmos moldes teóricos de outrora.

Verifica-se que, como consequência do dogma da neutralidade na prestação jurisdicional, o magistrado tornou-se um agente político próximo da lei, mas afastado da realidade e despido de sensibilidade para lidar com os conflitos intersubjetivos. Ao mesmo tempo, constata-se que a atuação judicial calcada numa racionalidade estrita não é mais suficiente para lidar com a complexidade atual das relações sociais e com a crise do sistema democrático. Não há que se empreender tantos esforços na manutenção de uma ordem jurídica que é intrinsecamente injusta; que concede maiores condições de fala e de representação política a uns poucos e, que, por isso, acaba refletindo os anseios de minorias privilegiadas. Não pode subsistir a figura do magistrado neutro, que insiste em não reconhecer as consequências nefastas de uma postura asséptica frente a tantas mazelas sociais.

A despeito de sua importância, o tema da neutralidade na prestação jurisdicional não é tratado por muitos estudiosos. JosÉ RENATO NALINI é um dos poucos autores que trabalha o assunto. Segundo ele, o cenário de profunda desigualdade que assola a sociedade brasileira, assim como as promessas da Carta Republicana - que traz a igualdade como um de seus valores supremos, e a redução das desigualdades como um de seus objetivos fundamentais -, exige que o magistrado se liberte do invólucro da neutralidade. Para esse autor, o juiz de que o Brasil contemporâneo necessita deve ter a coragem de posicionar-se perante os conflitos que lhe são apresentados no afã de compensar o desequilíbrio que muitas vezes se observa entre as partes de um processo, através de uma tutela específica e mais atenta às condições de quem se encontra materialmente em posição

\footnotetext{
${ }^{168}$ Atualmente a doutrina brasileira está avançando nessa seara e muitos já admitem a possibilidade de revisão judicial do mérito do ato administrativo, principalmente em face dos preceitos da ordem constitucional. Entretanto, a jurisprudência ainda parece relutante sobre esse assunto.
} 
inferior. A esse respeito, NALINI pondera:

Se a lei não funciona como meio de aperfeiçoamento da igualdade, mediante eliminação das desigualdades fáticas, o juiz não está impedido de fazê-lo, no caso concreto, ao exercer a jurisdição. É ele, assim como os demais Poderes do Estado, encarregado de fazer cumprir as promessas do constituinte. Não é um organismo supraestatal ou extraestatal. Integra o Estado e é destinatário nas normas fundantes que prevêem no futuro, uma pátria justa, fraterna e solidária. ${ }^{169}$

Nesse sentido, um magistrado que se deparasse com um litigante representado em juízo por advogado despreparado, possivelmente contratado em razão da insuficiência de recursos, poderia adotar posições bastante distintas. Diante de uma petição inicial mal redigida, confusa, com deficiências que inclusive comprometessem a inteligibilidade da pretensão formulada, o juiz que preferisse manter-se na assepsia e neutralidade não hesitaria em indeferir a inicial. Afinal de contas, o art. 295, inciso I, do Código de Processo Civil é claro ao estabelecer que "a petição inicial será indeferida quando for inepta". Por sua vez, o magistrado mais sensível à situação da parte, determinaria a emenda da inicial. Entretanto, mesmo dentre aqueles que preferissem essa última opção, haveria os que se limitariam a conceder o prazo para que a inicial fosse emendada, enquanto outros, mais sensibilizados pelas circunstâncias do caso concreto, indicariam expressamente o defeito da exordial, porque muito provavelmente o advogado sequer saberia encontrá-lo. Nalini afirma que os magistrados que tomam tal atitude

[...] assistem ao demandante mal representado, de maneira a não invalidar o seu esforço em direção a obter uma resposta do Estado-juiz. Se ambas as posturas são tecnicamente corretas, o ângulo ético não pode deixar de se inclinar para esta última. É o reconhecimento de que nem sempre se debate em juízo uma questão que envolva partes similares, com a mesma situação social ou econômica, assistidas igualmente por profissionais de alto coturno. ${ }^{170}$

Percebe-se, assim, que romper com o dogma da neutralidade na prestação jurisdicional acarreta profundas transformações no relacionamento entre o juiz e as partes. Segundo NALINI, esse debate conduz, necessariamente, ao tema da alteridade. O juiz que não é neutro, ou seja, que tem a coragem de sair do invólucro artificial que o protege do contato com as mazelas sociais com as quais lida, é aquele que reconhece o "colocar-se no lugar do outro" como condição indispensável ao bem julgar. Por tais razões, esse autor afirma que a imagem do juiz equidistante das partes, eternizada no célebre "triângulo chiovendiano", deve ceder lugar à figura de um magistrado que vivencia profundamente o

\footnotetext{
${ }^{169}$ NALINI, José Renato. Ética da Magistratura - Comentários ao Código de Ética da Magistratura Nacional - CNJ. São Paulo: Revista dos Tribunais, 2009. p. 71.

${ }^{170}$ Idem, ibidem.
} 
caso, que tenta sentir como cada uma das partes e assimilar os seus dramas pessoais.

A esse respeito, podemos trazer à lume as afirmações de WARAT, no sentido de que o racionalismo positivista-normativista que fundamenta a ciência jurídica buscou "estabelecer as condições de produção de uma espécie de inteligência emocional para o Direito, quer dizer, formas de razão que permitam evitar as decisões emocionais e as decisões arbitrárias" ${ }^{171}$. Segundo ele, tentou-se criar mecanismos institucionais de controle do subjetivismo das decisões, que deveria ser eliminado a qualquer custo, sob pena de se comprometer a objetividade do sistema jurídico-legal. Contudo, essa pretensão, além de impossível, estava calcada numa visão que confundia os terrenos da sensibilidade e da arbitrariedade, como se constituíssem uma mesma dimensão emocional. Por tais motivos, a prática jurídica de modo geral - o que inclui o processo de tomada das decisões judiciais -, envolvida pelas abstrações do raciocínio lógico-dogmático estrito, deixou de refletir a respeito dos conflitos intersubjetivos a partir do campo do sensível. Nas palavras de Warat:

\begin{abstract}
Em nome da necessidade de controlar a arbitrariedade do julgador o racionalismo abortou as possibilidades de uma interpretação de decisões sensíveis, extirpou dos operadores do Direito a sua sensibilidade. E a magistratura decide de forma insensível o que as partes do conflito necessitam. A decisão insensível não deixa de ser uma forma de decidir arbitrariamente. Uma decisão distante da justiça ${ }^{172}$.
\end{abstract}

Percebe-se, assim, que o tema da alteridade foi expurgado da razão jurídica desde o seu nascedouro, o que afetou sobremaneira a forma de decidir dos juízes, que foram incentivados a atuar de maneira asséptica, neutra, segundo os cânones de uma lógica jurídica formal e abstrata, e que tiveram anestesiado o seu lado humano, sensível, que não poderia transparecer nas decisões tomadas. Entretanto, em face das exigências dos novos desafios sociais contemporâneos, evidencia-se cada vez mais a insuficiência do paradigma do juiz convidado de pedra. Direcionam-se nesse mesmo sentido as conclusões de LIDIA REIS DE AlMEIDA PRADO, ao tratar do tema:

Nesta época de grandes transformações, em que as contradições trazidas pelo novo exigem a revisão de velhos posicionamentos, também os magistrados assim como todos os demais operadores jurídicos - participam das perplexidades que atingem os jurisdicionados. Impotente para fazer frente a essas transformações com a celeridade necessária e a eficiência desejável, o Judiciário sofre os problemas do Estado contemporâneo, que ainda não se adaptou à velocidade das mudanças dos últimos 50 anos. (...). A restrição do Direito à norma - de caráter abstrato e geral - não consegue conviver com a nova idéia de Justiça, que implica uma grande confiança no poder criativo do julgador, de quem se espera uma sensibilidade muito refinada para lidar com o sempre mutante contexto social. (...). Assim, o juiz contemporâneo, envolvido com o

${ }^{171}$ WARAT, Luis Alberto. A rua grita Dionísio! Lumem Juris Editora: Rio de Janeiro, 2010, p. 57

${ }^{172}$ Idem, ibidem, p. 56. 
caso, poderá recolocar o Judiciário, em seu lugar de sustentáculo da democracia e de refúgio certo da esperança coletiva. Um magistrado, que tenha vivências de alteridade no ato de julgar, terá maior possibilidade de outorgar aos jurisdicionados boas decisões. ${ }^{173}$

A referida autora também trata do tema da necessidade de alteridade no exercício na magistratura, porém, com base em conceitos da psicologia analítica desenvolvidos por CARl Gustav Jung, em especial, no arquétipo anima-animus.

Discípulo dissidente de Freud e criador do conceito de inconsciente coletivo, JUNG sustentava existirem tantos arquétipos quantas fossem as situações possíveis de serem vivenciadas pelos seres humanos. Constructos históricos, os arquétipos resultam das experiências acumuladas ao longo dos séculos da evolução da espécie humana e formam, segundo Jung, o conteúdo do inconsciente coletivo: um registro inconsciente, em cada ser humano, de todas as vivências experimentadas por seus ancestrais que são, de alguma maneira, guardadas, e que formam um núcleo de características que definem o ser humano enquanto tal.

Em vários livros de sua vasta obra ${ }^{174}$, JUNG denomina anima o arquétipo do feminino, que remonta ao imaginário coletivo a respeito da mulher constituído ao longo dos milhares de anos da civilização, desde a experiência com nossa condição animalesca até os dias de hoje. A anima reúne todos os atributos relacionados ao papel sócio-cultural da mulher, tais como a sensibilidade, o instinto maternal, a intuição e a criatividade. De outro lado, ele chama de animus o arquétipo do masculino, que reúne todas as qualidades geralmente atribuídas ao homem, tais como a racionalidade, a força e a assertividade, e que constituem a ideia coletiva que se faz a respeito do masculino, gerada a partir de toda a experiência cultural da nossa espécie.

Embora, de modo geral, estejam mais presentes no homem as características do animus e na mulher da anima, ambos podem viver os atributos arquetípicos do sexo oposto, uma vez que, para JUNG, todos nós podemos vivenciar infinitos arquétipos. Aliás, para esse autor, na medida em que o ser humano se torna capaz de lidar com características arquetípicas tão diversas, ele passa por um processo de autoconhecimento que o leva a uma existência mais plena. A esse processo JUNG denominou individuação.

Ocorre que, com a repressão do feminino operada na cultura ocidental e a

\footnotetext{
${ }^{173}$ PRADO, Lidia Reis de Almeida. O Juiz e a Emoção. $3^{\text {a }}$ Ed. Campinas: Millennium, 2005, pp. 87-88, 93 e 100 .

${ }^{174}$ Sua obra completa compreende 18 volumes, todos traduzidos para o português.
} 
consequente exacerbação da racionalidade, a dimensão do afeto e de todas as características relacionadas com o feminino, tais como a criatividade e a intuição, foram relegadas a segundo plano. Essa supervalorização da forma racional de se conceber a realidade - como se esta não pudesse ser compreendida a partir de outros atributos que não a razão - foi justamente a mola propulsora do desenvolvimento das ciências, que repercutiu nas diversas áreas do saber, dentre elas, o Direito.

Assim, as muitas funções estatais que envolvem a sua produção se identificaram com essa lógica, que privilegia a concepção pragmática acerca do Direito e que se relaciona especificamente com o animus. Em consequência disso, no que tange à função do magistrado, percebemos que ela, desde o início, se identificou com as características do animus, pois não se podia cogitar de juízes que atuassem com base noutro paradigma que não o da racionalidade.

Contudo, essa exacerbação dos aspectos que constituem o arquétipo masculino - e a consequente repressão daqueles caracterizadores do arquétipo feminino - tornam a atividade judicial excessivamente hermética, tecnicista, distante da dimensão do afeto e da sensibilidade. E, como todo reducionismo, impede que as questões que chegam aos magistrados sejam examinadas em sua completude. É assim que, a partir da psicologia analítica, Lidia REIS DE AlMEIDA PRADO, em seu O Juiz e a Emoção, discute em que medida o resgate das características arquetípicas da anima na função de julgar pode contribuir para que esta seja exercida de maneira mais equilibrada e com vistas à alteridade - esta representada, por JUNG, pela vivência conjunta e harmoniosa entre as polaridades arquetípicas anima e animus. Segundo a autora,

\begin{abstract}
A alteridade é o arquétipo da anima na personalidade do homem e do animus na personalidade da mulher, que possibilita o encontro do $E u$ com o Outro dentro da totalidade (self), em um clima de respeito pelas diferenças. (...). O arquétipo da anima, por meio de suas manifestações, pode ser um importante aliado (embora não seja domesticável), porque alivia a pressão das tensões afetivas e dos estados de ânimo desenvolvendo no homem a habilidade para os relacionamentos, por possibilitar que cada um seja visto como realmente é. Quanto aos juízes, a integração dos predicados desse arquétipo viabiliza que as partes sejam consideradas em sua humanidade e com o mínimo de preconceitos. (...). Assim, a anima, arquétipo da democracia, através de seus atributos, em especial da inventividade e do sentimento, pode surgir como agente catalisador da transformação do magistrado para atender a esse anseio coletivo. (...) os valores da democracia somente serão atingidos no dinamismo da alteridade (ou seja, sob a regência do arquétipo dos animus/anima). ${ }^{175}$
\end{abstract}

${ }^{175}$ PRADO, Lidia Reis de Almeida. O Juiz e a Emoção. $3^{\text {a }}$ Ed. Campinas: Millennium, 2005, pp. 58, 71 e 93. 
Reconhecer a insuficiência do paradigma de neutralidade no exercício da judicatura e a urgência em se resgatar o valor da alteridade como condição indispensável à tomada de decisões judiciais mais justas leva a concluir pelo necessário protagonismo da magistratura. NALINI o defende a partir das ideias do magistrado francês ANTOINE GARAPON, que identificou três tipos de justiça na atualidade. A primeira delas seria a justiça ritual, qual seja, a que se realiza nas salas de audiência e que focaliza o indivíduo, numa espécie de corporificação do liberalismo econômico do século XIX. A segunda seria a justiça burocrática, que, por sua vez, estaria mais próxima da administração e, portanto, seria mais afeita a critérios de desempenho e produtividade do que à de legalidade. Essa modalidade centra suas preocupações na busca por fórmulas que propiciem a solução de litígios em massa e está pautada na automatização dos processos e não na qualidade da resposta jurisdicional prestada. Por fim, a chamada justiça descentralizada ou de proximidade, que prioriza a participação do magistrado junto à sociedade e propõe uma atuação para além dos gabinetes, um contato direto com os conflitos até mesmo antes que eles se tornem litígios. Trata-se de uma ampliação do espectro de atuação do magistrado, que deixa de agir somente "mediante provocação" e parte para o território do conflito, participando de Conselhos de Segurança, colaborando para a reintegração social do egresso do sistema carcerário, atenta para a situação de moradores de rua, sem teto, sem terras, e de outras minorias excluídas. A justiça de proximidade traduz-se numa forma renovada de atuação judicial, na qual o magistrado busca levar a cabo o seu papel de agente encarregado de fazer cumprir as promessas da Constituição. E não é possível compreender esse novo paradigma senão a partir da inadequação, ruptura e necessidade de superação da figura do juiz neutro.

O tema (im)possibilidade da neutralidade na prestação jurisdicional também é tratado por LUIS ROBERTO BARROSO, que situa a imparcialidade do magistrado como um dos aspectos do imperativo de neutralidade no exercício da judicatura. Sustenta esse autor:

\footnotetext{
A neutralidade se dilui em muitos aspetos diferentes. Alguns deles não são de difícil implementação, como a imparcialidade - ausência de interesse imediato na questão - e a impessoalidade - atuação pelo bem comum, e não para o favorecimento de alguém. Basta a seriedade e vontade de fazer bem feito para atender a tais imperativos. Mas a neutralidade pressupõe algo impossível: que o intérprete seja indiferente ao produto do seu trabalho. É claro que há uma infindável quantidade de casos decididos pelo Judiciário que não mobilizam o juiz em sentido nenhum que não o de burocraticamente cumprir seu dever. Outros tantos casos, porém, envolvem a escolha de valores e alternativas possíveis. ${ }^{176}$
}

176 BARROSO, Luis Roberto. Interpretação e Aplicação da Constituição. Fundamentos de uma 
E prossegue, parecendo chegar ao âmago da questão:

A idéia de neutralidade do Estado, das leis e de seus intérpretes, divulgada pela doutrina liberal-normativista, toma por base o status quo. Neutra é a decisão ou a atitude que não afeta nem subverte as distribuições de poder e riqueza existentes na sociedade, relativamente à propriedade, renda, acesso às informações, à educação, às oportunidades, etc. Ora bem: tais distribuições - isto é, o status quo - não são fruto do acaso ou da ordem natural. Elas são produto do direito posto. E, frequientemente, nada têm de justas. A ordem social vigente é fruto de fatalidades, disfunções e mesmo perversidades históricas. Usá-la como referência do que seja neutro é evidentemente indesejável, porque instrumento de perenização da injustiça. ${ }^{177}$

A alusão que o autor faz à manutenção do status quo viabilizada pela atuação neutra da magistratura nada mais significa do que a perpetuação do senso comum teórico na ciência e na prática jurídicas. A sua reprodução através de uma prestação jurisdicional indiferente às consequências dos julgamentos realizados constitui um sério entrave ao dinamismo do Direito, pois aniquila o potencial emancipatório da atuação judicial. $\mathrm{O}$ magistrado que não atenta para a existência do senso comum teórico dos juristas funciona como uma engrenagem dessa máquina que se pretende manter em estado de inércia, formada pela ordem jurídica estatuída, que nem sempre regula as relações sociais de maneira justa. Assim, os juízes devem empreender esforços para desconstruir o senso comum teórico, fazendo disso uma arma contra a injustiça representada pela manutenção de estruturas jurídico-sociais iníquas. E, nessa tarefa, é de fundamental importância perceber que o dogma da neutralidade na prestação jurisdicional integra esse senso comum teórico que ora se combate.

Por fim, ressalta-se que o tema da neutralidade no exercício da magistratura relaciona-se intimamente com a questão do imperativo de independência do Poder Judiciário. De acordo com NALINI,

A independência de um juiz é um dos traços característicos do Estado de Direito. $\mathrm{Na}$ verdade, esta opção de convívio político implica a independência do Poder Judiciário, da qual a independência do juiz é correlativa. Um juiz só pode ser independente. Senão, não será juiz. (...). Expressa a independência ao Poder, teria sido insuficiente a proclamação, não fosse o corolário: garantir ao juiz aplicar o direito livre de interferências condicionantes. O julgador precisa estar inteiramente livre para sua missão. ${ }^{178}$

Assim, lutar pela consolidação de condições que favoreçam a independência dos

dogmática constitucional transformadora. $7^{\mathrm{a}}$ ed. Saraiva: São Paulo, 2009, p. 292

177 Idem, ibidem, p. 293.

${ }^{178}$ NALINI, José Renato. Op. Cit, p. 46. 
julgamentos surge como um imperativo no Estado Democrático de Direito contemporâneo, porque somente um Judiciário independente poderá atuar como agente transformador da realidade. Os magistrados não podem ficar presos aos conglomerados de ideologia cristalizados sob o senso comum teórico dos juristas, pois, do contrário, pensarão agir com independência, quando, na realidade, atuarão para a manutenção e reforço de suas próprias amarras, estas representadas pela cultura jurídica estandardizada.

Por tais razões, parece possível sustentar que a independência do Poder Judiciário está intimamente ligada à necessidade de consciência dos magistrados a respeito da existência do senso comum teórico e, principalmente, de iniciativas para com ele romper. Defender a "não neutralidade" implica, portanto, defender essa independência, a liberdade de atuação sem a qual o juiz não pode exercer a sua função. É importante frisar que a defesa da "não neutralidade" não significa um repúdio ao ordenamento jurídico, mas à atuação judicial que não questiona as estruturas legais, doutrinárias e jurisprudenciais consolidadas, que não pensa, em termos mais amplos, sobre o que elas representam e quais os seus condicionantes históricos. Trata-se de um repúdio à postura daqueles que se contentam com o raciocínio simplista e cômodo do tão falado "silogismo judicial" em que a premissa maior é o fato, a menor é a norma, e a conclusão o julgamento. Decidir o destino das pessoas exige mais do que tratá-las segundo uma equação lógico-matemática... 


\section{CONSIDERAÇÕES FINAIS}

O presente trabalho dispôs-se a analisar o dogma da neutralidade na prestação jurisdicional e a problematizá-lo filosoficamente em face da atual crise de legitimidade das instituições brasileiras, dentre elas, o Poder Judiciário. Conforme vimos, esse imperativo de neutralidade no exercício da magistratura nasceu juntamente à consolidação do Estado moderno liberal, fundado, dentre outros, sob o princípio da separação dos poderes. Para compreender o processo histórico que culminou com o surgimento dessa nova forma de Estado e, portanto, do imperativo de neutralidade no exercício da magistratura, foi necessário entender a influência exercida pelo projeto filosófico da Modernidade e, por conseguinte, pelo Iluminismo.

A intensa racionalização política, econômica e cultural ocorrida na Europa, a partir do século XVII, decorrente da profunda valorização do indivíduo preconizada pelo ideal iluminista, viabilizou uma série de mudanças nas formas de organização da sociedade de então. Somadas ao surgimento do capitalismo e ao crescente acúmulo de poder da burguesia, as transformações culturais ocorridas no bojo do Iluminismo culminaram no questionamento das bases do Antigo Regime, em que o soberano centralizava todos os poderes do Estado. Nasce, assim, um novo modelo estatal, mais adequado aos interesses mercantis e capitalistas dessa burguesia em ascensão, em que os princípios da legalidade e da separação dos poderes assumem grande importância, como fator de limitação do poder exercido pelo soberano.

Como vimos, à época do surgimento do Estado Moderno era a lei que garantia o tratamento igualitário entre os cidadãos, coibia os abusos do soberano e representava a vontade popular. A exigência de neutralidade na prestação jurisdicional, portanto, foi criada a serviço de um sistema jurídico pautado na legalidade estrita, o que soava bastante coerente. Mantendo-se neutro, o juiz respeitaria a divisão de poderes e, assim, garantiria o funcionamento de um Estado justo, porque respaldado no fiel cumprimento da lei, ou seja, no desejo do povo de ter suas condutas reguladas e julgadas conforme sua própria autodeterminação - lembrando ser esta resultante da filosofia das Luzes.

Entretanto, esse paradigma de neutralidade não se mostra mais adequado para lidar com os problemas sociais contemporâneos. Isso porque, na atualidade, verifica-se que o Estado Democrático é cada vez menos representativo e, em consequência, o sistema legal perde paulatinamente sua legitimidade. As leis não mais resultam da vontade do povo: são 
antes fruto de intensas articulações políticas que atendem, em grande parte, interesses de elites econômicas que desejam ver regulamentadas a seu favor matérias que dizem respeito à coletividade. A democracia parece ser exercida pelos cidadãos apenas de quatro em quatro anos, quando são convocados às urnas. Após o sufrágio, eles não são chamados a debater e decidir os destinos da pólis e, neutralizados, remanescem numa posição de sujeição em relação às ações (e omissões) dos administradores e parlamentares eleitos. Em tempos de crise das instituições, do Direito e da própria função judicante, torna-se indispensável assumir a "não-neutralidade" e a necessidade de resgate da sensibilidade como novo paradigma de atuação da magistratura. Não pode subsistir a postura neutra dos juízes frente a um universo que os conclama a se posicionar.

O presente trabalho buscou, no pensamento de WARAT, o aporte teórico necessário para discutir, filosoficamente, o problema da atuação do juiz, a partir da intersecção Direito e linguagem. Esse autor mostrou-nos, através da sua proposta de uma semiologia do poder e da identificação do senso comum teórico dos juristas, que os próprios enunciados da ciência do Direito não são neutros. Também enfatizou que não é possível produzir conhecimento jurídico neutro, porque a própria linguagem não é neutra, livre de influências externas e de condicionantes histórico-sociais.

Com a constatação da existência de um senso comum teórico na prática dos juristas, ganha relevo a questão da presença do poder na ciência do Direito e da necessidade de se enxergar a ideologia veiculada por trás desse senso comum, o que somente poderia ser feito, segundo WARAT, através de uma semiologia do poder. É importante frisar que, segundo esse autor, os achados obtidos por esse saber semiológico aplicado ao Direito levam a concluir pela necessidade de construção de uma “epistemologia das significações”, uma refundação epistemológica da ciência do Direito, que não ignora o fato de que o poder tem primazia sobre a prática e a experiência jurídicas.

Como também vimos, a exigência de neutralidade na prestação jurisdicional tornou-se uma crença consolidada, petrificada, que é tomada como verdade e que, por estar arraigada na cultura e na racionalidade jurídicas, não é compreendida como uma representação ilusória que deve ser criticada e revista. Ou seja, transformou-se em senso comum teórico. Assim, considerando-se que o paradigma da neutralidade não se sustenta diante de uma realidade que exige do magistrado que se posicione perante os conflitos que lhe são apresentados, é inevitável concluir que o juiz não pode se manter inerte, como o convidado de pedra ou a boca que diz as palavras da lei. A própria exigência de 
neutralidade no exercício da judicatura foi integrada ao senso comum teórico e, portanto, precisa ser abalada, desconstruída.

Ademais, ainda que se discorde da perspectiva acima apresentada, segundo a qual o dogma da neutralidade na prestação jurisdicional integra o senso comum teórico e, portanto, deve ser rechaçado, é imprescindível afirmar que, a partir da perspectiva da Filosofia da Linguagem, essa pretendida neutralidade sequer é possível. Como também se mostrou ao longo deste trabalho, após a virada linguística não é mais possível ignorar o papel criativo do magistrado, que não consegue simplesmente dizer as palavras da lei, uma vez que as normas não possuem um significado em si: é o intérprete-aplicador que, no momento de aplicá-las, confere-lhes significação. É impossível ao magistrado manter-se distante do Direito com o qual lida, porque ele, de certa forma, o constitui. A tão sonhada neutralidade mostra-se não somente indesejável, como impossível, pois não é dado ao juiz afastar-se do Direito se ele próprio é um dos responsáveis pela configuração que a realidade jurídica assume.

Conclui-se, assim, que o juiz não é e nem pode ser neutro. Primeiro, porque não há neutralidade no ato de conhecer, uma vez que o sujeito influi na construção do objeto. Segundo, porque, ainda que não queiram ou não se deem conta, os juízes reproduzem o senso comum teórico, que não é neutro, mas repleto de representações ideológicas que albergam valores cristalizados por uma ordem jurídica que não necessariamente é justa.

Se o senso comum teórico dos juristas é formado pelas diversas representações, imagens, crenças e ilusões presentes na ciência e na prática do Direito, que se autoproclamam fruto de um saber científico, mas que, na realidade, são repletas de ideologia, então, manter-se na neutralidade implica atuar em prol da manutenção das significações ideológicas petrificadas sob o manto do senso comum teórico. Ou seja, o magistrado que insiste em exercer o seu mister de forma neutra, sem questionar a adequação e o conteúdo das estruturas jurídicas, alheio às causas socioeconômicas dos conflitos que chegam até ele e sem preocupar-se com as consequências de sua decisão, terá uma atuação ainda mais ideológica do que poderia supor. $O$ juiz que escolhe não posicionar-se defenderá, na realidade, os valores inscritos na ordem jurídica, ainda que sejam injustos. E incorrerá no mesmo erro que maculou a teoria kelseniana: despreocupando-se com o aspecto ideológico da ciência e da prática do Direito, tornar-se-á recipiente a ser preenchido com toda e qualquer ideologia. Não passará de marionete que se movimenta não com liberdade, mas em obediência a ordens que sequer sabe de onde 
provêm.

WARAT propôs-se a pensar se seria um possível um Direito cheio de vida, e, por isso denunciou o senso comum teórico, que é tudo aquilo que o torna morto, sem um começo que possa ser recomeçado. Uma história já escrita e cujo fim já se sabe. Assim, a identificação e o rompimento com o senso comum teórico dos juristas significa uma tentativa de devolver ao Direito a vida que lhe foi roubada, ou seja, a sua capacidade emancipatória, de transformação das estruturas sociais e de realização da Justiça. E o presente trabalho, ao situar o dogma da neutralidade na prestação jurisdicional no interior desse senso comum teórico que Warat almeja desconstruir, pretendeu-se como uma colaboração aos esforços realizados pelo autor no sentido de dotar o Direito de um caráter verdadeiramente libertador.

Lidar com a obra de LUIS ALBERTO WARAT constituiu um desafiante trabalho de garimpo e de bricolagem. Afinal, a fragmentação e o eterno desconstruir são notas características de seu pensamento, como ele próprio afirma:

Como se situa o meu pensamento? Se você, leitor, se está fazendo essa pergunta,
recomendo-lhe situar-me dentro da corrente dos desconstrutivistas franceses.
Você pode ver-me como um intelectual da desconstrução. Penso com categorias
desconstrutivas, antropofágicas, com as que procuro reconstruir noções como
autonomia, Direito, e enfatizar a formulação das condições para a construção da
subjetividade política. Tento confrontar-me com aqueles que empregam um
vocabulário institucionalmente aceito com passividade, tanto no Direito, quanto
na epistemologia, a Ética e a política, entre outros saberes que circulam
institucionalmente controlados, sem poder dar conta do que agora nos está
passando em termos de exclusão social. ${ }^{179}$

Assim, trabalhar com o pensamento waratiano é como tentar montar um intrincado e complexo quebra-cabeça que, no fundo, sabe-se incompleto, porque em constante movimento. E nesse esforço de ordenação e, portanto, de racionalização, corre-se o risco de uma parte já montada do quebra-cabeça desaparecer, enquanto se procuram as peças faltantes. É por isso que não podíamos deixar de esclarecer, nesse ponto do presente trabalho, que WARAT parece deixar incompleto o seu projeto de construção de uma semiologia do poder. Na realidade, de certa forma, ele o abandona antes de terminá-lo.

Após muitos anos de esforços envidados para tornar o Direito uma prática emancipatória, WARAT chega à conclusão de que essa tão sonhada emancipação nunca se tornará realidade caso não se atente para as formas de produção da subjetividade, ou seja,

${ }^{179}$ WARAT Luis Alberto. A rua grita Dionísio! Lumem Juris Editora: Rio de Janeiro, 2010, p. 36. 
para a questão da alteridade. E, não bastasse isso, o autor conclui que há certos aspectos da subjetividade humana que são inexprimíveis, em especial as emoções. E se expressá-las não é possível, então o estudo da linguagem em termos semiológicos, para ele, perde importância. Entretanto, se de um lado, esse parece ser o sentimento do autor, por outro, dúvidas podem ser levantadas a esse respeito, porque na sua mais recente publicação, $A$ Rua Grita Dionísio!, WARAT recorre bastante à semiologia, apesar de fazê-lo em outros termos - utiliza-a junto à psicanálise para tentar compreender os processos psicológicos e comunicacionais que propiciam o encontro do $E u$ com o Outro, ou seja, que viabilizam o exercício da alteridade.

É o próprio WARAT quem expressa essa guinada de seu pensamento, no posfácio do livro $O$ Direito e sua Linguagem, escrito 20 anos após a primeira edição da obra:

\begin{abstract}
Os encarregados de aplicar as leis, os produtores das teorias jurídicas, os professores as escolas de Direito (os construtores das significações jurídicas) forjam uma realidade imaginária (colocada na perspectiva do senso comum) que fazem prevalecer como naturalismo. (...). Durante muitos anos tentei efetuar a crítica dessa realidade imaginária do Direito. $\mathrm{Na}$ medida em que fui me aproximando da psicanálise as objeções se debilitaram. Agora, me inclino a pensar que seria de interesse um tratamento diferenciado do Direito como instituição do social e como parte do imaginário radical. Em ambos os casos falaríamos a coisas bem diferentes. Assim, resultaria absurdo tentar dizer alguma coisa da interpretação da lei desde a perspectiva do imaginário radical. Nesse lugar a questão é a da subjetividade. Nesse lugar a hermenêutica deve ceder seu espaço para a semiologia do desejo. Convém também relevar que não tem sentido falar de desejos, ou do amor, na interpretação da lei. ${ }^{180}$
\end{abstract}

Faz-se esse comentário não simplesmente em respeito ao referencial teórico adotado neste trabalho - o que soaria extremamente desumanizado, como se houvesse apenas uma obra e não o seu autor -, mas à pessoa cujas ideias brilhantes se recorreu.

Num primeiro momento, isso parece diminuir a importância da discussão travada ao longo do presente trabalho. Afinal, como as reflexões aqui apresentadas puderam basear-se uma fase quase renegada pelo próprio autor estudado? A isso se responde facilmente a partir das ideias do próprio WARAT: se o seu discurso é polifônico, então não pode pretender a si mesmo enquanto verdade, o que soaria autoritário e sufocaria as diversas vozes nele presentes. Ademais, a obra possui existência autônoma em relação ao seu autor, pois, uma vez criada, adquire vida própria. E, principalmente por ser escrita, pode assumir os mais variados sentidos, uma vez que como WARAT sempre fez questão de ressaltar, as palavras não possuem significação unívoca. Assim, um texto pode receber

${ }^{180}$ WARAT, Luis Alberto. O Direito e sua Linguagem. Buenos Aires: Cooperadora de Direito e Ciências Sociais, 1976, p. 120. 
diferentes abordagens, sem que isso configure desrespeito ao autor ou à sua obra. De tal sorte, embora WARAT, de certo modo, tenha renegado a fase de sua obra enfatizada neste trabalho, os conceitos semiológicos desenvolvidos por ele não perderam valor, o que justifica a sua utilização. Aliás, o presente trabalho também pode ser encarado como uma tentativa de se evidenciar o quão atual é a obra de WARAT, em especial os seus escritos das décadas de 1970 e 1980.

De tudo o que foi dito a respeito do pensamento waratiano, talvez seja possível afirmar que uma das grandes tarefas a que WARAT se propôs foi contribuir para o reconhecimento da impossibilidade de neutralidade nas ciências em geral e, claro, na ciência jurídica. Afinal, é assim que ele mesmo parece sintetizar parte de suas preocupações:

\begin{abstract}
As metáforas de um iluminismo cativo de um ideal de progresso, como meta irrenunciável de nossa espécie, cedem ante o reconhecimento de crises inesperadas que alteram radicalmente a realidade em que vivemos. Crises que, ao afetar-nos, afetam, também, uma prolongada concepção da produção científica do conhecimento. Crises que recordam a necessidade de levar em conta a singularidade dos acontecimentos. (...). No fundo, o fim da neutralidade da ciência, revelando que ela serve para construir e destruir realidade, assim como alterar o curso da subjetividade e das ações. Uma falta de neutralidade que obriga a considerar em seu lugar o aspecto ético da produção do conhecimento. Somos responsáveis das realidades que construímos. A idéia da neutralidade já não nos salva. Construímos o que conhecemos e surgimos como indivíduos (sujeitos) nesse processo de construção ${ }^{181}$.
\end{abstract}

Se reconhecer o fim da neutralidade nas ciências confere responsabilidade àquele que a produz, o mesmo se passa na magistratura. Reconhecer que não é possível uma atuação judicial neutra também torna responsável aquele que a realiza. E se é necessário um paradigma substituto - porque, afinal, parece que os homens sempre necessitam de um sentido de orientação, como a crise da racionalidade estrita mostrou -, que ele seja o da alteridade. Que no lugar do juiz neutro, venha o juiz que saiba colocar-se no lugar das partes, que não seja indiferente ao fragmento de destino que para elas determina. Isso porque, como NALINI bem resumiu:

O juiz da torre de marfim, o convidado de pedra, inerte à dor embrulhada nos autos, o burocrata inerte, o compilador de jurisprudência, todos estes já não atendem às necessidades contemporâneas de um juiz efetivamente empenhado em fazer justiça. Missão que nem sempre se confunde com a erudita dicção do direito, ou na elaboração dos malabarismos procedimentais ininteligíveis até pelos bacharéis. Às vezes, fazer justiça é muito simples. A experiência do juiz e a exata compreensão do valor simbólico de sua toga podem fazer milagres no

${ }^{181}$ WARAT, Luis Alberto. Territórios Desconhecidos - A procura surrealista pelos lugares do abandono do sentido e da reconstrução da subjetividade. Florianópolis: Fundação Boiteux, 2004, p. 530. 
projeto de pacificação social. Para isso é necessário despir-se do autoritarismo, da prepotência, da arrogância e de outras vestimentas que costumam acompanhar a imaturidade - em qualquer idade - de alguns magistrados que se olvidam estar a serviço do povo, e não entronizados no altar das celebridades ${ }^{182}$.

Trata-se de mais uma hercúlea tarefa que se atribui ao magistrado - o que remete ao primeiro parágrafo deste trabalho. Talvez não seja demais ressaltar que, para auxiliá-lo, nos parece de grande valia o pensar filosófico. Afinal, não fosse ele, sequer se teria chegado a estas conclusões. E para finalizar, mais uma vez recorremos a WARAT, para quem a filosofia deve ser encarada como "um potencial de afeto que permita a aceitação da alteridade a partir dos sentimentos". E, a respeito do desafio ético concreto que o pensar filosófico evoca, o autor completa: "para encontrar-se com o outro, é preciso poder aceitar suas diferenças. De fato, as diferenças não são aceitas por processos inteiramente racionais. As diferenças são aceitas quando se consegue um encontro afetivo com o outro e na medida em que se saiba querer".

É disso que se trata. De juízes que saibam querer. Querer mudar, enfrentar, transformar. Que, despojando-se da ilusória mas confortável proteção daquele escudo chamado neutralidade, estejam dispostos a encarar a responsabilidade que assumiram e da qual não podem escapar. Que tenham a coragem necessária para encontrar-se com o Outro. Esse Outro que se apresenta diante deles como "partes do processo", mas que, na verdade, nada mais são do que partes deles próprios.

${ }^{182}$ NALINI, José Renato. Op. Cit., p. 76. 


\section{REFERÊNCIAS BIBLIOGRÁFICAS}

ABBAGNANO, Nicola. Dicionário de Filosofia. Edição revista e ampliada. São Paulo: Martins Fontes, 2007

AMB - Associação dos Magistrados Brasileiros. Opinião Consultoria. A imagem das Instituições Públicas Brasileiras. Setembro/2007. Brasília, DF. Disponível em www.amb.com.br Acesso em 17/05/2008

. Pesquisa AMB 2005. Coord. Maria Tereza Sadek. Disponível em www.amb.com.br Acesso em 04/04/2006.

Pesquisa AMB 2006. Coord. Maria Tereza Sadek. Disponível em www.amb.com.br Acesso em 21/10/2008.

ALTHUSSER, Louis. Filosofia e Filosofia Espontânea dos Cientistas. Lisboa: Editorial Presença, 1976.

BITTAR, Eduardo. C. B. O Direito na Pós-Modernidade. Rio de Janeiro: Forense Universitária, 2005

. Linguagem Jurídica. São Paulo: Ed. Saraiva, 2003.

BACHELARD, Gaston. Epistemologia. Rio de Janeiro: Jorge ZAHAR Editor, 1977.

BARTHES, Roland. Aventura Semiológica São Paulo: Martins Fontes, 2001.

. O Neutro. São Paulo: Martins Fontes, 2003.

. O Grau Zero da Escrita. São Paulo: Martins Fontes, 2004.

. Mitologias. 12 ed. Madrid: Siglo xxi editores, 1999.

. Elementos de Semiologia. Lisboa: Edições 70, 2007

BARROS, Sergio Rezende de. Montesquieu e a Ideologia Mecanicista. São Paulo, 2009, p. 02 (mimeo).

BAKHTIN, MIKHAIL. Estética da Criação Verbal. São Paulo: Martins Fontes, 2003. 
Problemas da poética de Dostoievski. Rio de Janeiro: Forense Universitária, 2005.

BOLZAN, José. Habermas - razão e racionalização. Porto Alegre: Unijuí, 2005

BRANDÃO, Junito de Souza. Mitologia grega. vol.01. São Paulo: Ed. Vozes, 1986

CINTRA, Antônio Carlos de Araújo. GRINOVER, Ada Pellegrini. DINAMARCO, Cândido Rangel. Teoria Geral do Processo. 9a ed. São Paulo: Malheiros, 1993.

COELHO, Luis Fernando. Lógica Jurídica e Interpretação das Leis. $2^{\text {a }}$ ed. Rio de Janeiro, Forense: 1981.

Teoria Crítica do Direito. $3^{\text {a }}$ ed. Belo Horizonte: Del Rey, 2003. . Saudades do Futuro. Curitiba: Juruá, 2007.

ELIADE, Mircea. Mito e realidade. São Paulo: Ed. Perspectiva, 2007.

FRANK, Jerome. Law and the modern mind. New York, Anchor Books/Doubleday \& Company, Inc., 1948.

FERRAZ JR., Tercio Sampaio. Direito, Retórica e Comunicação. $2^{\mathrm{a}}$ ed. São Paulo: Saraiva, 1997.

Introdução ao Estudo do Direito - técnica, decisão, dominação, $2^{\mathrm{a}}$ ed. São Paulo: Atlas, 1994.

GARAPON, Antoine. O juiz e a democracia - O guardião das promessas. Trad. Maria Luiza de Carvalho. $2^{\text {a }}$ ed. Rio de Janeiro: Ed. Revan, 2001.

Bem julgar - ensaio sobre o ritual judiciário. Lisboa: Piaget, 1997.

GILISSEN, John. Introdução Histórica ao Direito. $3^{\text {a }}$ ed. Lisboa: Fundação Calouste Gulbenkian, 2001.

GROTERA, Luís. O Judiciário Ausente da Mídia é um Risco para a Democracia. In Cidadania e Justiça. Rio de Janeiro: AMB, 1998.

JAPIASSU, Hilton. O Mito da Neutralidade Científica. $2^{\mathrm{a}}$ ed. Rio de Janeiro: Imago, 1981. 
. Como nasce a ciência moderna - e as razões da filosofia. Rio de Janeiro:

Ed. Imago, 2007

KAUFMANN, Arthur. Introdução à Filosofia do Direito e à Teoria do Direito Contemporâneas. Lisboa: Fundação Calouste Gulbenkian, 2002.

Filosofia do Direito. Lisboa: Fundação Calouste Gulbenkian, 2007.

KANT, Immanuel. Resposta à pergunta: O que é o Esclarecimento? Tradução de LUIZ Paulo RouAnEt. Disponível em http://geocities.ws/eticaejustica/esclarecimento.pdf Último acesso em: 26 Mar 2008

KELSEN, Hans. Teoria Pura do Direito. Coimbra, Armênio Armando Editor, 1974.

LOPES, José Reinaldo Lima. O Direito na História - lições introdutórias. São Paulo: Max Limonad, 2000.

MIGUEL, Luis Felipe. Em Torno do Conceito de Mito Político. Dados, Rio de Janeiro, v. 41, n. 3, 1998 Disponível em

http://www.scielo.br/scielo.php?script=sci_arttext\&pid=S001152581998000300005\&lng= en\&nrm=iso Último acesso em 25.12.2009

MONDARDO, Dilsa. 20 Anos Rebeldes - Direito à luz da proposta filosófico pedagógica de Luis Alberto Warat. Florianópolis: Habitus Editora, 2000.

MONTESQUIEU, Charles de Secondat. Do espírito das leis. Livro XI, capítulo 6. Tomo I. São Paulo: Ed. Difusão Européia do Livro, 1962

NALINI, José Renato. Recrutamento e Preparo dos Juízes. São Paulo: Revista dos Tribunais, 1992.

. Curso de Deontologia da Magistratura. São Paulo: Saraiva, 1992.

. O Juiz e o Acesso à Justiça. 2a ed. São Paulo: Revista dos Tribunais, 2003.

. A Rebelião da Toga. $2^{\text {a }}$ ed. Campinas: Millennium, 2008.

. Ética da Magistratura - Comentários ao Código de Ética da Magistratura Nacional - CNJ. São Paulo: Revista dos Tribunais, 2009.

NOBRE, Ana Karena. O formalismo jurídico e o mito da neutralidade estrita. In Revista Cidadania e Justiça. Ano 7. Número 13. Brasília: AMB, 2004. 
OLIVEIRA, Manfredo Araújo de. Reviravolta Lingüístico-Pragmática na Filosofia Contemporânea. $3^{\text {a }}$ ed. São Paulo: Edições Loyola, 2003.

OLIVEIRA JR., José Alcebíades de. (Org.). O poder das metáforas: homenagem aos 35 anos de docência de Luis Alberto Warat. Porto Alegre: Livrara do Advogado, 1998.

PRADO, Lídia Reis de Almeida. O Juiz e a Emoção. $3^{\text {a }}$ ed. Campinas: Millennium, 2005.

Racionalidade e Emoção na Prestação Jurisdicional. In COLTRO, Antônio Carlos Mathias; ZIMERMAN, David. Aspectos Psicológicos na Prática Jurídica. 2a ed. Campinas: Millennium, 2008.

A Questão da Segurança Jurídica: há neutralidade do juiz? In Revista da ESMAPE, v. 1, p. 12, 2006.

Influências dos Aspectos Psicológicos do Juiz sobre a Sentença. In GUILHERME, Luiz Fernando do Valle de Almeida. (Org.). Estudos em homenagem ao acadêmico Ministro Moreira Alves. São Paulo: Fiúza Editores, 2003.

- Neutralidade e imparcialidade dos juízes? In GROENINGA, Giselle Câmara; PEREIRA, Rodrigo (Coord.). Direito de família e psicanálise: rumo a uma nova epistemologia. Rio de Janeiro: Imago, 2003.

A Lógica do Razoável na Teoria da Interpretação Jurídica. In Revista Justiça e Democracia, da Associação dos Juízes para a Democracia, São Paulo, v. 1, 1996. ROUANET, Sergio Paulo. Mal-estar na Modernidade. São Paulo: Martins Fontes, 2003. SAFATLE, Vladmir. Espelhos sem imagens: mimesis e reconhecimento em Lacan e Adorno. Trans/Form/Ação. Marília, v.28, n.2, 2005. Disponível em: http://www.scielo.br/scielo.php?script=sci_arttext\&pid=S0101-

31732005000200002\&lng=en\&nrm=iso Último acesso em 21.Nov. 2009.

SAVIGNY, Friedrich K. Von. Metodologia Jurídica. São Paulo: Rideel, 2005.

SOUZA, Artur Cesar de. A Parcialidade Positiva do Juiz. São Paulo: Editora Revista dos Tribunais, 2008.

STRECK, Lenio Luiz. Hermenêutica Jurídica e(m) crise. $4^{\mathrm{a}}$ ed. Porto Alegre: Livraria 
do Advogado, 1999.

. BOLZAN, José Luiz de. Ciência Política e Teoria do Estado. $6^{\text {a }}$ ed. Porto Alegre: Livraria do Advogado, 2008.

WARAT, Luis Alberto. Derecho al Derecho. Buenos Aires: Abeledo Perot, 1969.

. CUNHA, Rosa Cardoso da. Ensino e Saber Jurídico. Rio de Janeiro: Livraria O Dorado, 1972

. Semiótica e Direito. Buenos Aires: Eikon, 1972.

. Et alii. (org.). Temas para uma Filosofia Jurídica. Buenos Aires: Cooperadora de Direito e Ciências Sociais, 1974.

O Direito e sua Linguagem. Buenos Aires: Cooperadora de Direito e Ciências Sociais, 1976.

. Mitos e Teorias Na Interpretação da Lei. Porto Alegre: Sintesis, 1979.

. A Pureza do Poder. Florianópolis: UFSC, 1982.

Técnicas Argumentativas Na Pratica Judicial. In Revista Seqüência (UFSC), v. 08, n. 09: Florianópolis, 1984.

. O Manifesto do Surrealismo Jurídico. São Paulo: Acadêmica, 1988.

. Introdução Geral ao Direito vol. I - Interpretação da lei. Temas para uma reformulação. Porto Alegre: Sergio Antonio Fabris, 1994.

Introdução Geral ao Direito vol. II - a epistemologia jurídica da modernidade. Porto Alegre: Sergio Antonio Fabris, 1995.

.; PEPE, A. M. Filosofia do Direito - uma introdução crítica. São Paulo: Moderna, 1996.

. Introdução Geral Ao Direito - Vol. III - O direito não estudado pela teoria jurídica moderna. Porto Alegre: Sergio Antonio Fabris, 1997.

. Territórios Desconhecidos - A procura surrealista pelos lugares do abandono do sentido e da reconstrução da subjetividade. Florianópolis: Fundação 
Boiteux, 2004.

. Epistemologia e Ensino do Direito - O sonho acabou. Florianópolis: Fundação Boiteux, 2004.

Surfando na Pororoca. Florianópolis: Fundação Boiteux, 2004.

A Rua Grita Dionísio! Lúmen Júris Editora: Rio de Janeiro, 2010.

ZOJA, Luigi. A história da arrogância - psicologia e limites do desenvolvimento humano. São Paulo: Axis Mundo, 2000 


\section{RESUMO}

SENA, Jaqueline Santa Brígida. O dogma da neutralidade na prestação jurisdicional: reflexões jusfilosóficas a partir do pensamento de Luis Alberto Warat. 2010. $125 \mathrm{f}$. Dissertação de mestrado. Faculdade de Direito, Universidade de São Paulo, 2010.

O dogma da neutralidade na prestação jurisdicional nasce juntamente com o Estado moderno liberal como corolário do princípio da separação dos poderes e como tentativa de minimização da influência do subjetivismo do julgador sobre as decisões tomadas. Naquela época, acreditava-se que somente julgamentos pautados estritamente nos comandos legais é que seriam justos, porque respeitariam a vontade popular expressa nas normas. Entretanto, ao lado desse imperativo, que ainda se faz presente na atualidade, parece haver uma crise do sistema democrático, que vê reduzida paulatinamente sua representatividade, com a consequente perda da legitimidade das leis, até então expressão da vontade popular. Diante desse quadro, o presente trabalho se propôs a problematizar, filosoficamente, o imperativo de neutralidade na prestação jurisdicional, indagando a respeito de sua adequação ao contexto social brasileiro contemporâneo. Para tanto, recorreu-se à obra de LUIS ALBERTO WARAT, jusfilósofo que, dentre outras contribuições, desenvolveu a concepção de senso comum teórico dos juristas, como tentativa de evidenciar a existência de uma série de representações, imagens e crenças consolidadas na ciência e na prática do Direito, que são tidas como enunciados científicos mas que não passam de mero senso comum cristalizado e carregado de ideologia. Assim, a partir da obra waratiana, situada no contexto da Filosofia da Linguagem, tentou-se responder à seguinte questão: é possível cogitar de neutralidade na prestação jurisdicional se os magistrados, em sua prática cotidiana, lidam com um saber jurídico repleto de ideologia e se o próprio ato de conhecer não parece sujeito a critérios de objetividade? A conclusão a que se chegou é que a atuação judicial não é, e nem pode ser, neutra. E, também, que a neutralidade no exercício da magistratura, frente a um cenário de profundas desigualdades sociais, não é desejável, porque implica a manutenção e reprodução do senso comum teórico dos juristas, com a consequente perpetuação do status quo e o aniquilamento do potencial transformador da magistratura.

PALAVRAS-CHAVE: Poder Judiciário; Neutralidade; Crise da razão moderna; Senso comum teórico dos juristas; Luis Alberto Warat. 


\begin{abstract}
The dogma of neutrality in adjudication comes together to the Modern liberal state as a corollary of the principle of separation of powers, in attempt to minimize the influence of the subjectivism of the magistrates on the decisions taken. At that time, it was believed that only judgments based strictly on the ruled legal commands were fair, because they respected the popular will expressed in their standards. However, alongside this imperative, which is still present nowadays, there seems to be a crisis of the democratic system, which loses gradually its representativeness, so that the laws are not more expression of the will of the people. Considering this situation, this work intended to question, philosophically, the need for neutrality in adjudication, asking about their adequacy to Brazilian contemporary social context. Therefore, appealed to the work of LUIS ALBERTO WARAT, author that, among other contributions, developed the concept of "theorist common sense of jurists" in an attempt to prove the existence of a series of representations, images and beliefs statements in science and practice of Law, which are regarded as scientific statements but are only common sense crystallized and loaded with ideology. Thus, from WARAT's work, which is situated in the context of Philosophy of Language, we tried to answer the following question: Is it possible for judges to act with neutrality if they, in their daily practice, deal with a legal knowledge full of ideology and the act of knowing cannot reach objectivity? The conclusion reached is that the judicial action is not and cannot be neutral. And, also, that the neutrality of the magistrates is not desirable, considering the scene of deep social inequalities in Brazil contemporary, because it involves the maintenance and reproduction of common sense theory of lawyers, with the consequent perpetuation of the status quo and the annihilation of the transforming potential from the judiciary.
\end{abstract}

KEYWORDS: Judicial Power; Neutrality; Crisis of modern reason; theorist common sense of the jurists; Luis Alberto Warat. 